\title{
The distribution and timing of molybdenite mineralization at the El Teniente Cu-Mo porphyry deposit, Chile
}

\author{
Edward T. Spencer ${ }^{1}$, Jamie J. Wilkinson ${ }^{1,2}$, Robert A. Creaser ${ }^{3}$ and Jose Seguel ${ }^{4}$ \\ Department of Earth Science and Engineering, Imperial College London, United Kingdom, SW7 2AZ \\ Geology Department, Natural History Museum, London, United Kingdom, SW7 5BD \\ Department of Earth and Atmospheric Sciences, University of Alberta, Edmonton, Alberta, Canada, T6G 2E3 \\ CODELCO División El Teniente, Rancagua, Chile
}

Primary Author email: es406@imperial.ac.uk

The El Teniente Cu-Mo porphyry deposit, Chile, is one of the world's largest and most complex porphyry ore systems, containing an estimated pre-mining resource of approximately $95 \mathrm{Mt} \mathrm{Cu}$ and 1.4 Mt Mo. Although Cu mineralization at the deposit is quite well studied, little work has focused specifically on the distribution and timing of Mo mineralization. Combined grade, vein and breccia distribution analysis reveals that deposit-wide Mo grades of 0.01 to 0.06 wt.\% are strongly controlled by the abundance of main mineralization (type 6a) quartz \pm molybdenite veins. These show a clear spatial relationship with several felsic-intermediate intrusions and appear to develop outwards and upwards into Cu-rich (type 6b-7b) quartz-chalcopyrite veins and (type 8) chalcopyriteanhydrite \pm bornite veins with sericitic alteration halos. High precision Re-Os molybdenite dating reveals that these linked vein types did not develop in a single, deposit-wide evolution, but are diachronous, related to distinct episodes of hydrothermal activity associated with the emplacement of diorite finger porphyries and the composite Teniente Dacite Porphyry. These units acted as effective, short-lived ( $<100,000$ years) conduits for pulses of Mo and Cu-bearing hydrothermal fluids between 6.3 and $4.6 \mathrm{Ma}$. The rapid thermal contraction of each system during mineralization led to extensive overprinting of Mo-rich veins by their lower temperature, Cu-rich equivalents. Separate pulses in magmatic-hydrothermal activity are separated by distinct gaps of up to 300,000 years, during which Mo-mineralizing activity appears to have gone into quiescence.

Mo grades exceeding $0.06 \mathrm{wt} \%$ correspond to the presence of molybdenite-bearing, late mineralization stage, tourmaline-cemented (type 9) and anhydrite-carbonate tgypsum (type 10) veins and breccias. These are abundant at shallow mine levels and show a close spatial relationship with a series of concentric faults associated with the Braden Breccia pipe. Mineralization in this paragenetic stage is relatively short-lived and occurs in all parts of the deposit between 4.80 and 4.58 Ma. The generally Cu-poor nature of the late mineralization stage is attributed to the prior preferential extraction of $\mathrm{Cu}$ from the underlying magma chamber in earlier mineralizing events. This led to the late exsolution of oxidized, Mo-rich fluids that may have undergone further enrichment by 
remobilizing Mo from main mineralization-type veins associated with the Teniente Dacite Porphyry. The formation of the Braden Breccia pipe is likely to have occurred in a single cataclysmic event at approximately 4.58 Ma, which cut the Mo-rich tourmaline breccias and created a distinct Mo-rich grade halo at shallow mine levels. With the exception of minor mineralization associated with small dacitic dikes at approximately 4.42 Ma, the Braden event marked the termination of Mo deposition. 


\section{Introduction}

The El Teniente Cu-Mo porphyry deposit, Chile $\left(34^{\circ} 05^{\prime} \mathrm{S}, 70^{\circ} 21^{\prime} \mathrm{W}\right)$, is located approximately $70 \mathrm{~km}$ southeast of Santiago (Fig. 1) on the western margin of the Andean Cordillera and within the confines of the central Chilean porphyry $\mathrm{Cu}$ belt. This supergiant porphyry is the world's largest underground $\mathrm{Cu}$ mine, hosting a pre-mining resource of approximately $95 \mathrm{Mt}$ of fine $\mathrm{Cu}$ (Camus, 2002; Stern et al., 2010). Molybdenum, present in the form of molybdenite, is obtained purely as a by-product of Cu mining with typical ore grades of $<0.03$ wt.\%. However, the great size of El Teniente makes it the world's largest known resource of Mo (Sillitoe, 2010) with a current and mined resource total of approximately 2.5 Mt (Camus, 2002). Despite this, relatively little attention has focused on the distribution and timing of Mo mineralization. Such information is important for developing the Mo resources at the mine and can enhance our understanding of the magmatic and hydrothermal fluids responsible for Mo transportation and mineralization in porphyry systems.

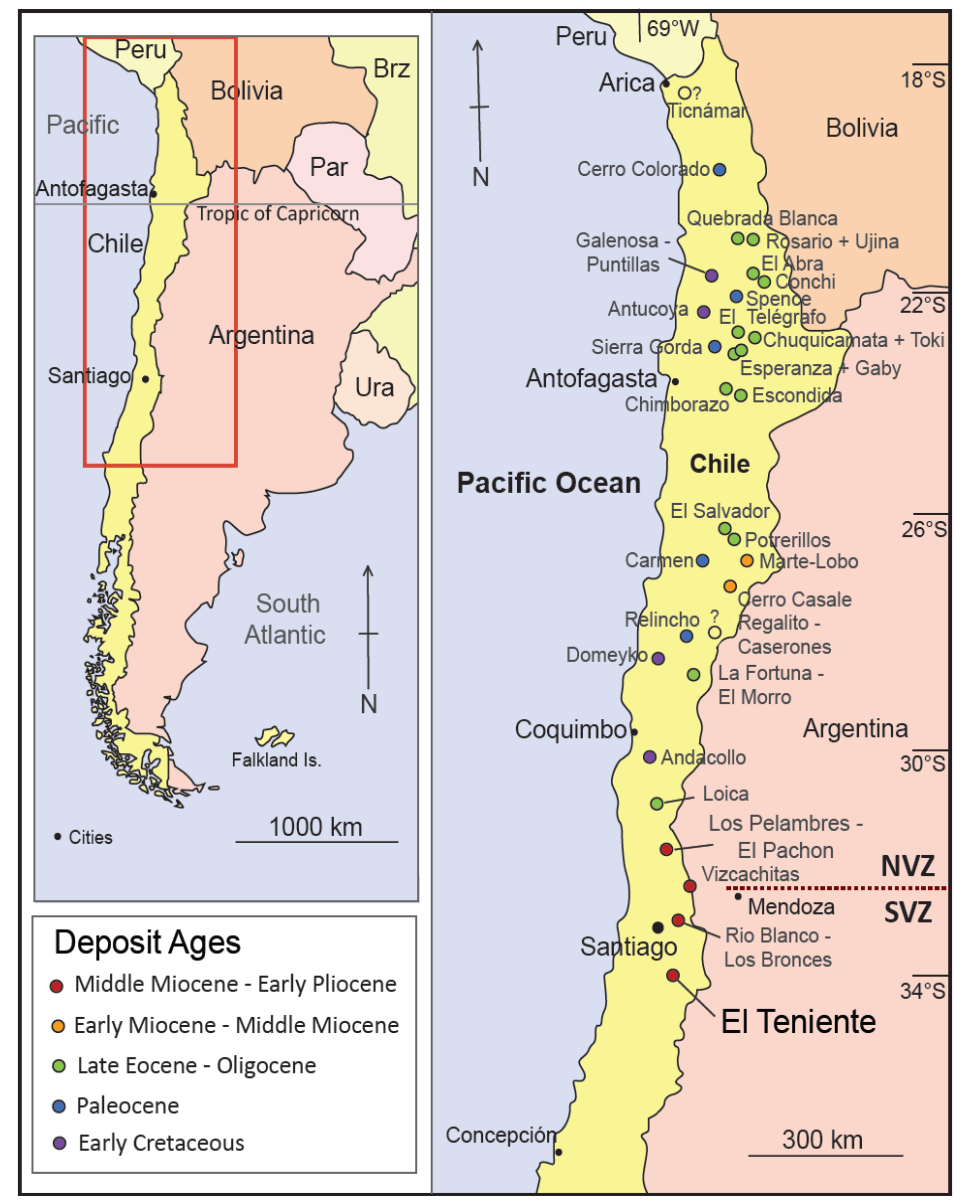

Fig. 1: Location map of the El Teniente Cu-Mo porphyry deposit and other major porphyry $\mathrm{Cu}-\mathrm{Mo}$ and $\mathrm{Cu}$ systems in the central and northern Chilean porphyry $\mathrm{Cu}$ districts. Dotted red line = rough location of the boundary between the Northern Volcanic Zone and The Southern Volcanic Zone (SVZ). Adapted from Vry et al. (2010) and Singer et al. (2008). 
Geological relationships (e.g. Cannell et al., 2005; Vry et al., 2010), paleomagnetism (Astudillo et al., 2010) and Re-Os dating of molybdenite (Cannell 2004; Maksaev et al., 2004) indicate that mineralization at El Teniente resulted from multiple brecciation-veining events associated with the emplacement of a number of felsic-intermediate intrusions. Molybdenite is interpreted to have been precipitated in every alteration and mineralization stage at the deposit, but in highly variable amounts (e.g. Hernández et al., 1980; Cuadra 1986). Locally there is also evidence for overprinting of early Mo-bearing vein stages by later molybdenite (Cannell et al., 2005; Vry et al., 2010). This apparent multi-phase evolution means that there is still uncertainty regarding the most important intrusions, breccias and veins with respect to Mo introduction.

A recent study at El Teniente highlighted the distinct decoupling in the spatial distribution of Mo and Cu (Vry et al., 2010). Similar decoupled zonation patterns have been recognized at a number of other porphyry deposits (e.g. El Salvador, Chile: Gustafson and Hunt, 1975; Bajo de la Alumbrera, Argentina: Ulrich and Heinrich, 2001; Butte, Montana: Rusk et al., 2008; Bingham Canyon, Utah: Landtwing et al., 2010; Redmond and Einaudi, 2010; Seo et al., 2012). At Bingham Canyon this was attributed to reduction and an increase in acidity in the evolving fluid source region (Seo et al., 2012). This led to the initial exsolution of oxidized fluids, which favored the early transport and deposition of $\mathrm{Cu}$ and retarded Mo deposition. Subsequent exsolution of more reduced and acidic fluids then favored molybdenite saturation, creating a Mo-rich vein overprint. At El Teniente, molybdenite-rich veins are commonly overprinted by chalcopyrite, suggesting different controls on decoupling (Vry et al., 2010). In order to identify these controls, better constraints on the distribution and timing of molybdenite mineralization relative to $\mathrm{Cu}$-sulfide deposition are required. These include accurate identification of the veins and breccias that are the most important hosts for $\mathrm{Cu}$ - and Mo-sulfides and their timing relationships in different parts of the deposit.

By combining grade distribution data with detailed drillcore analysis, this study aims to provide quantitative constraints on the distribution and abundances of different vein and breccia types and determine their relationships with $\mathrm{Mo}$ and $\mathrm{Cu}$ mineralization. In addition, Re-Os molybdenite geochronology was used in an attempt to provide better constraints on the timing of mineralization across the deposit. This technique is ideal because the ore mineral of interest is dated directly and the geochronometer displays closed behavior during post mineralization hydrothermal alteration an important factor in multistage mineralizing systems such as El Teniente (e.g., Stein et al., 1998; Selby and Creaser, 2001; Stein and Bingen, 2002; Bingen and Stein, 2003; Ootes et al., 2007; Bingen et al., 2008; Lawley and Selby, 2012). Previously, 18 molybdenite samples were dated at El Teniente 
using this technique (Cannell, 2004; Maksaev et al., 2004). These studies provided a general timescale for Mo mineralization but had several limitations:

- They only provided age determinations for molybdenite in a few vein and breccia types and excluded some Mo-rich stages, including veins and breccias related to the late mineralization stage;

- They used samples that were predominantly obtained from shallow mine levels in $\mathrm{Cu}$ rich parts of the deposit;

- They did not date molybdenite associated with a number of economically important intrusions and fault zones;

- They did not date different vein generations in a particular part of the deposit and therefore provided little information regarding the potential longevity of mineralization cycles;

- They did not fully test whether there was a deposit-wide evolution in mineralized vein types as suggested by previous studies (Cannell et al., 2005; Klemm et al., 2007);

- They did not provide enough samples to complete a full comparative study with crystallization and alteration ages obtained for the deposit (Clark et al., 1983; Cuadra, 1986; Maksaev et al., 2004).

Here, we have dated 11 geologically constrained vein and breccia samples from several Mo-rich zones in order to address some of these limitations. By combining these results with field observations and additional geochronological evidence (Clark et al., 1983; Cuadra, 1986; Maksaev et al., 2004) this study provides further evidence for episodic intrusion emplacement and mineralization at El Teniente, involving at least three major pulses of magmatism and related hydrothermal activity. 


\section{Deposit Geology}

\section{Deposit Geology}

Geological Setting

The tectonic setting, regional geology and magmatic-hydrothermal evolution of El Teniente have been the focus of numerous studies over the last 90 years (Lindgren and Bastin, 1922; Howell and Malloy, 1960; Camus, 1975; Charrier et al., 2002; Skewes et al., 2002; Maksaev et al., 2004, 2009; Cannell et al., 2005, 2007; Skewes and Stern, 2007; Klemm et al., 2007; Rabbia et al., 2009; Astudillo et al., 2010; Stern et al., 2010; Vry et al., 2010; Muñoz et al., 2012). Combined, these investigations have helped build an understanding of the magmatic and hydrothermal evolution of the deposit.

El Teniente is hosted within the Teniente Mafic Complex (TMC; Fig. 2); a thick package of mafic sills, stocks and volcaniclastics rocks of andesitic-basaltic composition (Howell and Mallloy, 1960; Maksaev et al., 2004; Cannell et al., 2005; Vry et al., 2010; Stern et al., 2010). This complex was emplaced between 15.2 and 7.5 Ma forming a >50 km³ laccolith within the $>2.5 \mathrm{~km}$-thick Miocene Farellones Formation (Lindgren and Bastin, 1922; Cuadra; 1986; Skewes et al., 2002, 2005). At approximately 7.0 Ma, crustal thickening led to the termination of volcanism in the Southern Volcanic Zone (SVZ: Fig. 1) and the inferred formation of a large magma chamber beneath El Teniente. The large volumes of water, sulfur, chlorine and $\mathrm{Cu}$ present at El Teniente indicate a mantle-derived parental magma body, contaminated by altered oceanic crust and sediments, with a likely volume exceeding $600 \mathrm{~km}^{3}$ (Stern, 1989, 1991; Cloos, 2001; Richards, 2003; Skewes et al., 2005; Skewes and Stern, 2007).

\section{Deposit Formation}

Between 6.5 and 4.5 Ma, temperature fluctuations and magma mixing are thought to have led to the buoyant rise and emplacement of a series of felsic-intermediate intrusions (Clark et al., 1983; Cuadra, 1986; Skewes et al., 2002; Maksaev et al., 2004; Cannell et al., 2005; Vry et al., 2010). The Sewell Quartz Diorite is the oldest intrusion and makes up the south-eastern quadrant of the mine area (Fig. 2). This is intruded by the A-Porphyry, the first extensively mineralized intrusion, on its northern margin. Although displaying a porphyritic texture, the A-Porphyry is an igneous breccia consisting of abundant TMC and Sewell Quartz Diorite clasts within an altered matrix of biotite, Kfeldspar, plagioclase, anhydrite and quartz (Cannell, 2004; Vry et al., 2010). SHRIMP U-Pb zircon 
dating of the Sewell Quartz Diorite and the A-Porphyry yielded a range of ages between 6.9 and 5.7 Ma (Maksaev et al., 2004; Fig. 3).

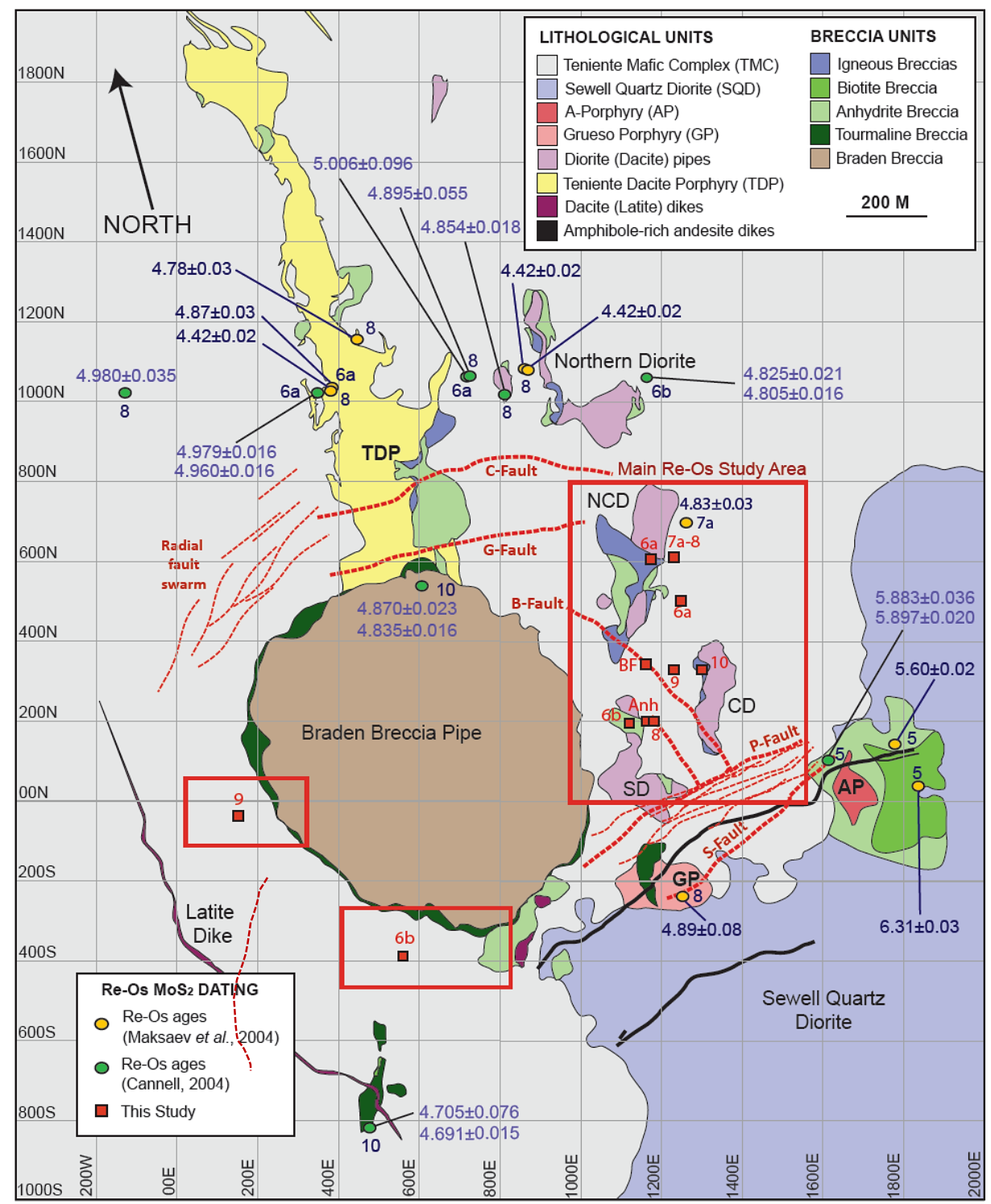

Fig. 2: Simplified geological map of El Teniente at an elevation of $\mathbf{2 1 6 5} \mathbf{m}$ above sea-level (asl) with units and breccias listed from oldest to youngest in accordance with previous studies (Maksaev et al., 2004; Vry et al., 2010). Map shows the location of drillcores analyzed during this study (dashed black lines) and transects selected for vein distribution analysis (solid black lines). The circles on the transect lines represent the start of each drillcore. DDH 1805 = vertical drillcore. The locations of the 18 vein and breccia samples dated in previous studies using the Re-Os molybdenite technique (Maksaev et al., 2004; Cannell 2004). Red squares = 11 samples dated during this study with numbers corresponding to vein types after the classification of Vry et al. (2010). BF = B-Fault sample (a major Mo-rich fault zone trending towards the northwest). Original map provided by CODELCO Chile Division El Teniente. Mine grid is oriented $14.5^{\circ}$ from true north.

Maksaev et al. (2004) stated that zircon ages from these units display bimodal distributions with dominant peaks occurring at $6.15 \pm 0.08$ and $6.46 \pm 0.11 \mathrm{Ma}$ and subordinate peaks at $5.59 \pm 0.17$ Ma and $5.67 \pm 0.19 \mathrm{Ma}$ respectively. This bimodality was recognised within individual zircon crystals, 
suggesting that two distinct crystallization events are recorded. Based on these data, and the fact that the A-Porphyry cuts the Sewell Quartz Diorite, it was suggested that the younger peaks in zircon ages may represent the final crystallization of the A-porphyry, whereas the older ages may represent the crystallization of Sewell Quartz Diorite. The range of U-Pb dates recorded within this unit (Fig. 3) led to the suggestion that the Sewell Quartz Diorite is a composite intrusion in which the separate intrusion boundaries are masked by subsequent phases of potassic and quartz-sericitic alteration (Maksaev et al., 2004).

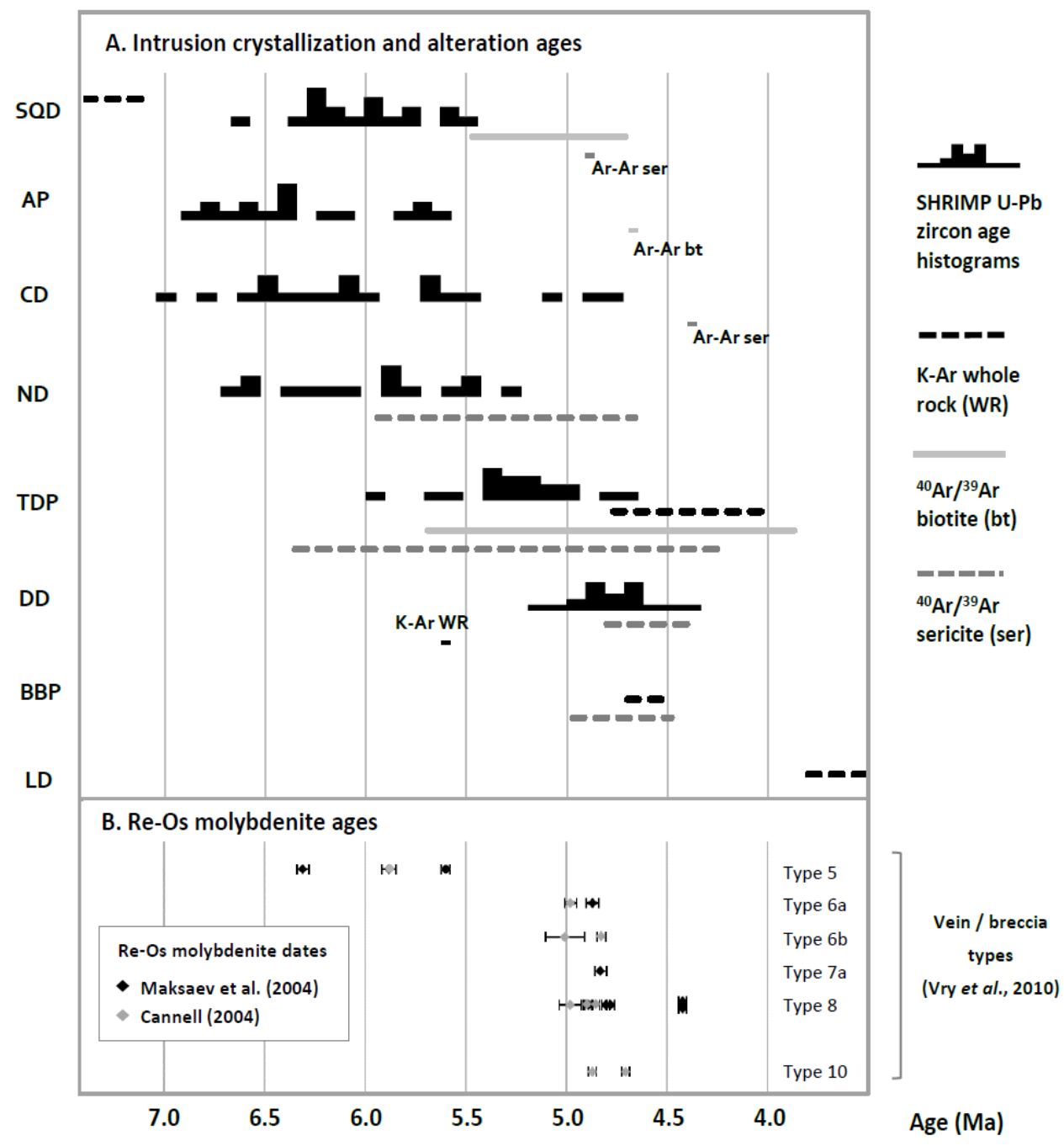

Fig 3: Compiled geochronology for the crystallization of intrusions and molybdenite mineralization at El Teniente. (A) Intrusion crystallization, biotite and sericite alteration (Quirt, 1972; Clark et al., 1983; Cuadra, 1986; Maksaev et al., 2004). Intrusions are listed in order of formation as reported in previous studies (Maksaev et al., 2004; Cannell et al., 2005; Vry et al., 2010). Histograms show temporal distribution of previously collected U-Pb zircon ages (Maksaev et al., 2004) divided into $0.1 \mathrm{Ma}$ intervals and ignoring any clearly anomalous outliers. ${ }^{40} \mathrm{Ar} /{ }^{39} \mathrm{Ar}$ step-heating and total fusion ages are combined. (B) Re-Os molybdenite ages for vein types collected in two previous studies (Maksaev et al., 2004; Cannell 2004). Vein types are given according to the vein classification scheme of Vry et al., (2010). For intrusion and Re-Os sample locations refer to Fig. 2. 
The Teniente Dacite Porphyry is cut by the Braden Breccia pipe which dominates the center of the deposit (Fig. 2). Several authors suggested that this rock-flour breccia formed between 4.7 and 4.6 Ma (e.g. Cannell et al., 2005) and that it may have marked the termination of significant shallow level mineralization (e.g. Cuadra, 1986). In contrast, Maksaev et al. (2004) proposed that the Braden Breccia pipe is a syn-mineralization diatreme that formed at approximately $4.8 \mathrm{Ma}$ and was succeeded by significant Mo and Cu mineralization. This interpretation was based on U-Pb zircon ages from a mineralized dacite ring dike encircling the Braden Breccia pipe, which displayed a unimodal distribution of spot ages with a weighted average of $4.82 \pm 0.09 \mathrm{Ma}$.

A number of magmatic and hydrothermal breccias are found cutting and enveloping all the porphyry intrusions previously described (Fig. 2). These include igneous-, biotite-, anhydrite-, tourmaline- and anhydrite-carbonate \pm gypsum-cemented breccias (Vry et al., 2010; see Fig. 4). Actinolite-, magnetite-, K-feldspar- and quartz-cemented breccias have also been described locally at the deposit (e.g. Skewes et al., 2002; Seguel et al., 2006; Vry et al., 2010). With the exception of early igneous breccias, all other breccia types are believed to be petrogenetically linked to vein stages that display similar mineralogy to the breccia cements and comparable alteration envelopes (Vry et al., 2010). However, distinct geochronological or fluid chemical evidence for these links has yet to be documented.

The zones of intense stockwork veining surrounding intrusion-breccia complexes at El Teniente are interpreted to represent the primary control on grade distribution (e.g. Maksaev et al., 2004, 2009; Vry et al., 2010). Three vein chronologies have been formulated using vein cross-cutting relationships, each identifying at least 13 distinct vein types (the El Teniente mine classification used since 2003; Cannell et al., 2005; Vry et al., 2010). In this study, the vein chronology of Vry et al. (2010) was adopted (Fig. 5). This sequence is interpreted to be applicable across the deposit and is divided into three paragenetic stages: (1) the premineralization stage, associated with potassic alteration (K-feldspar alteration and biotitization); (2) the main mineralization stage, consisting of quartz and/or anhydrite veins with alteration halos grading from minor potassic (type 5) to none (6a to $7 \mathrm{~b}$ ) to sericitic (type 8); (3) the late mineralization stage, consisting of veins containing tourmaline and sulfosalts, possibly related to the formation of the Braden Breccia pipe and its marginal breccia facies. Vein and breccia cross-cutting relationships reported by Vry et al. (2010) are consistent across the deposit with only rare reverse cross-cutting relationships reported. However, it is unclear whether this is due to the synchronous development of each vein type across the deposit or the diachronous development of similar, localized vein halos surrounding each intrusion. In addition, 
even though cross-cutting relationships are consistent, the exact relationship of each vein type with one another remains poorly understood, and as a result it is unclear whether any vein types developed coevally or cospatially, grading from one type into the other.

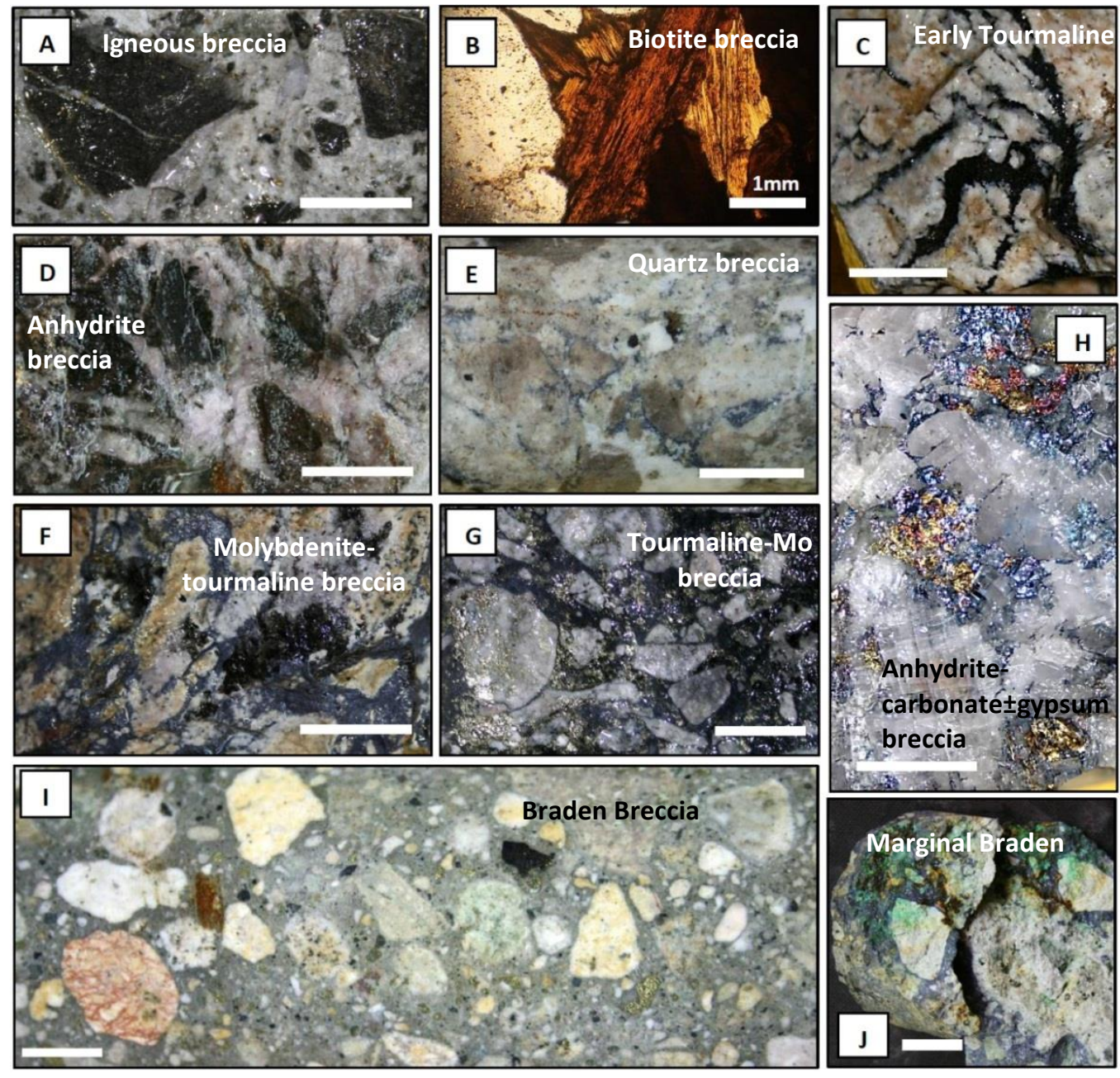

Fig. 4: A-J Magmatic and hydrothermal breccia types observed at El Teniente. (A) Igneous breccia showing angular TMC clasts in a quartz-feldspar matrix (1754-127.1). (B) Plane-polarized light photomicrograph of a biotite breccia sample proximal to the A-Porphyry with 2-5 $\mathrm{mm}$ long biotite laths in a fine biotite-quartz matrix (sample Bt Bx 1). (C) Early (pre-mineralization stage) barren tourmaline-cemented crackle breccia sampled at a shallow mine level to the east of the Braden Breccia pipe (1754-317.5). (D) Anhydritecemented breccia associated with the carapace of the Southern Diorite at shallow mine levels (2083-262.2). (E) Quartz-cemented breccia with minor K-feldspar and anhydrite in matrix surrounding clasts of the North Central Diorite (2215-49.8). Molybdenite mineralization predominantly occurs at the clast-matrix boundary. (F) Late mineralization stage tourmaline-cemented breccia to the east of the Braden Breccia pipe consisting of a molybdenite-rich matrix supporting highly altered diorite and TMC clasts (1754-285.9). (G) Marginal tourmaline breccia with tourmaline+molybdenite cement found at the western rim of the Braden Breccia pipe (2672-92.35). (H) Anhydrite-carbonate- and minor gypsum-cemented breccia supporting abundant bornite-chalcopyrite-molybdenite mineralization found in the southern section of the mine area (2672103.05). (I) Braden Breccia sample containing sub-angular to rounded clasts of several different lithologies in a rock flour matrix that contains fragmented chalcopyrite (2716-72.0). (J) Oxidized and altered hand specimen of the marginal breccia within the western rim of the Braden Pipe (2716-75.5). Matrix is molybdenite-rich with minor chalcopyrite oxidized to malachite. Scale bars $=1 \mathrm{~cm}$ in length. 
The vein chronology of Vry et al. (2010) was adopted as it is the only classification scheme that presents a clear distinction between Mo-rich type $6 a$ and 7a veins and chalcopyrite-bearing type $6 \mathrm{~b}$ and $7 \mathrm{~b}$ veins (Fig. 5). This detail is imperative in order to understand the decoupled nature of Mo and $\mathrm{Cu}$ mineralization. Molybdenite is recognized as an important vein constituent in 8 of the 13 vein stages reported (Fig. 5). These include type 3 pre mineralization stage veins, type 6a, 6b, 7a and 8 main mineralization stage veins and type 9 and 10 late mineralization stage veins. With the exception of type 7a veins, chalcopyrite is reported in all of these vein stages but in highly variable proportions, thus suggesting a significant overlap in Mo and Cu mineralization. Vry et al. (2010) suggested that type 7 and 8 veins are the most important veins in terms of both $\mathrm{Cu}$ and Mo grade distributions.

Of the eight molybdenite-bearing vein stages identified, six vein types (or their inferred associated breccias) have been previously dated using the Re-Os molybdenite geochronometer (Figs. 2, 3). These samples reveal a range of mineralization ages spanning a 1.9 m.y. period (Maksaev et al., 2004; Cannell, 2004). Maksaev et al. (2004) suggested that there were five distinct episodes of mineralization at $6.30 \pm 0.03,5.60 \pm 0.02,5.01-4.96,4.89 \pm 0.08$ to $4.78 \pm 0.03$, and $4.42 \pm 0.02 \mathrm{Ma}$. Nine additional Re-Os molybdenite ages reported by Cannell (2004) correlate well with these pulses and also display an apparent younging with paragenetic stage (Fig. 3). The similarity in the results of these two studies, and the interpreted close synchronicity of molybdenite mineralization with U-Pb zircon ages for the A-Porphyry, Diorites, Teniente Dacite Porphyry and the Braden Breccia pipe (Fig. 3 ), led to the conclusion that mineralization was closely associated with the formation of each of these intrusive units (Maksaev et al., 2004; Cannell, 2004; Cannell et al., 2005). However, the vein formation sequence has been interpreted as a deposit wide evolution (e.g. Cuadra, 1986; Arevalo et al., 1998; Klemm et al., 2007), with, for example, early stage veins only being associated with the oldest intrusions (Cannell et al., 2005). This may explain the lack of reverse cross-cutting vein and breccia relationships.

To date, almost all dated molybdenite samples have come from one shallow section across the northern part of the deposit and from the carapace of the A-Porphyry (Fig. 2). As a result, there is uncertainty regarding the timing of molybdenite mineralization across the entire deposit. In addition, the apparent deposit-wide evolution in vein paragenesis may be misleading because the oldest Mo-mineralized vein stages analyzed (type 5) were obtained from the oldest intrusions (the Sewell Quartz Diorite and the A-Porphyry) whereas the youngest veins and breccias analyzed (type 8 and 10) were spatially associated with the younger Teniente Dacite Porphyry and Braden Breccia 
pipe (Figs. 2, 3). As a result, these data alone cannot distinguish between a deposit-wide evolution in vein and breccia type (e.g. Cannell et al., 2005; Klemm et al., 2007) or a history involving multiple hydrothermal cycles (e.g. Maksaev et al., 2004; Vry et al., 2010; Astudillo et al., 2012).

Fig. 5 (next page): Vein chronology of Vry et al. (2010) with example photographs of each vein type. The classification is divided into 3 main paragenetic stages: Red rows = Pre-mineralization stage; Yellow = Main mineralization stage; Blue $=$ Late hydrothermal stage. Bold minerals $=$ main constituents. Molybdenite mineralization can be seen in type 3, 5, 6a, 6b, 7a, 8, 9 and 10 veins. (A) Type 1 Biotite-actinolite-chlorite vein with diffuse biotite halo in the Sewell Quartz Diorite (08/2483/13, DDH 2483, $294.90 \mathrm{~m}$, courtesy of Vry et al. (2010); (B) Type 2 vein with magnetite and quartz overprinted and replaced by significant chalcopyrite mineralization in the A-Porphyry (2305-178.1); (C) Quartz-biotite type 3 vein cut and overprinted by a molybdenite type 7a vein (2371-55.0); (D) Quartz-K-feldspar type 4a vein with wide, diffuse biotite halo in the A-Porphyry, cut and offset by small quartz type 6a veins (2305-57.95); (E) Type 4b vein with K-feldsparepidote- anhydrite + minor chlorite within the TMC, proximal to the Sewell Quartz Diorite (1888-62.7); (F) Type 5 anhydrite vein with minor molybdenite in the Southern Diorite (2083-207.0); (G) Type 6a quartz vein with significant molybdenite mineralization in the TMC at deep mine level (1805-381.3); (H) Type $6 \mathrm{~b}$ quartzchalcopyrite vein with early molybdenite at edges of vein and chalcopyrite in the center proximal to the North Central Diorite (1754-258.3); (I) Type 7a molybdenite vein cutting type 3 and 4a veins in the TMC proximal to the North Central Diorite (2230-175.2); (J) Network of chalcopyrite-rich type $7 \mathrm{~b}$ veins with minor quartz to the east of the North Central Diorite (2215-185.1); (K) Molybdenite-bearing type 8 anhydritequartz vein with sericitic alteration halo cut by a chalcopyrite-bearing type 8 vein proximal to the Teniente Dacite Porphyry (2661-174.4); (L) Type 9 tourmaline vein with minor molybdenite and chalcopyrite in sericite-altered section of the Teniente Dacite Porphyry south of the Braden Breccia pipe (2672-108.6). (M) Type 10 carbonate-anhydrite vein with quartz halo proximal to the Southern Diorite (2083-251.6); (N) Type 10 vein with large gypsum crystals from proximal to the Southern Diorite (2083-297.9). Mineral abbreviations: bt $=$ biotite, act $=$ actinolite, $\mathrm{chl}=$ chlorite, $\mathrm{cpy}=$ chalcopyrite, mag $=$ magnetite, anh $=$ anhydrite, $\mathrm{py}=$ pyrite, $\mathrm{plag}=$ plagioclase, $\mathrm{Kfsp}=\mathrm{K}$ feldspar, $\mathrm{ap}=$ apatite, $\mathrm{ep}=$ epidote, $\mathrm{mo}=$ molybdenite, bo $=$ bornite, tour $=$ tourmaline, $c b=$ carbonate, gyp $=$ gypsum, ten $=$ tennantite. ser $=$ sericite . 


\begin{tabular}{|c|c|}
\hline Vein & Vein Mineralogy and alteration halos \\
\hline \multirow{2}{*}{1} & bt-act \pm (chl-cpy) \\
\hline & bt halo \\
\hline \multirow{2}{*}{2} & mag $\pm q z-a n h-(c p y-p y)$ \\
\hline & original halo not preserved \\
\hline \multirow{2}{*}{3} & bt-qz $\pm a n h-(c h l-c p y-p y-m o)$ \\
\hline & qz-plag halo \\
\hline \multirow{2}{*}{$4 a$} & qz-Kfsp $\pm a n h-(a p-b t)$ \\
\hline & bt halo \\
\hline \multirow{2}{*}{$4 b$} & Kfsp-ep-anh-chl $\pm q z$ \\
\hline & local ep halo \\
\hline \multirow{2}{*}{5} & anh-qz $\pm c p y-p y-(b o-m o)$ \\
\hline & bt halo in the TMC/Kfsp or no halo in felsics \\
\hline \multirow{2}{*}{$6 a$} & qz-anh-Kfsp $\pm m o-b o-p y$ \\
\hline & no halo in TMC/Kfsp halo in felsics \\
\hline \multirow{2}{*}{$6 b$} & qz-cpy-anh-Kfsp $\pm m o-b o-p y$ \\
\hline & no halo in TMC/Kfsp halo in felsics \\
\hline \multirow{2}{*}{$7 a$} & mo $\pm(q z-a n h)$ \\
\hline & no halo \\
\hline \multirow{2}{*}{$7 \mathrm{~b}$} & cpy $\pm q z-a n h$ \\
\hline & no halo \\
\hline \multirow{2}{*}{8} & cpy-py-qz-anh-mo \\
\hline & ser-chl-qz halo \\
\hline \multirow{2}{*}{9} & tour-cb-anh \pm cpy-py-bo-mo \\
\hline & ser-chl-qz halo \\
\hline \multirow{2}{*}{10} & cb-anh-gyp \pm ten-cpy-py-bo-mo \\
\hline & ser-chl-qz halo \\
\hline
\end{tabular}
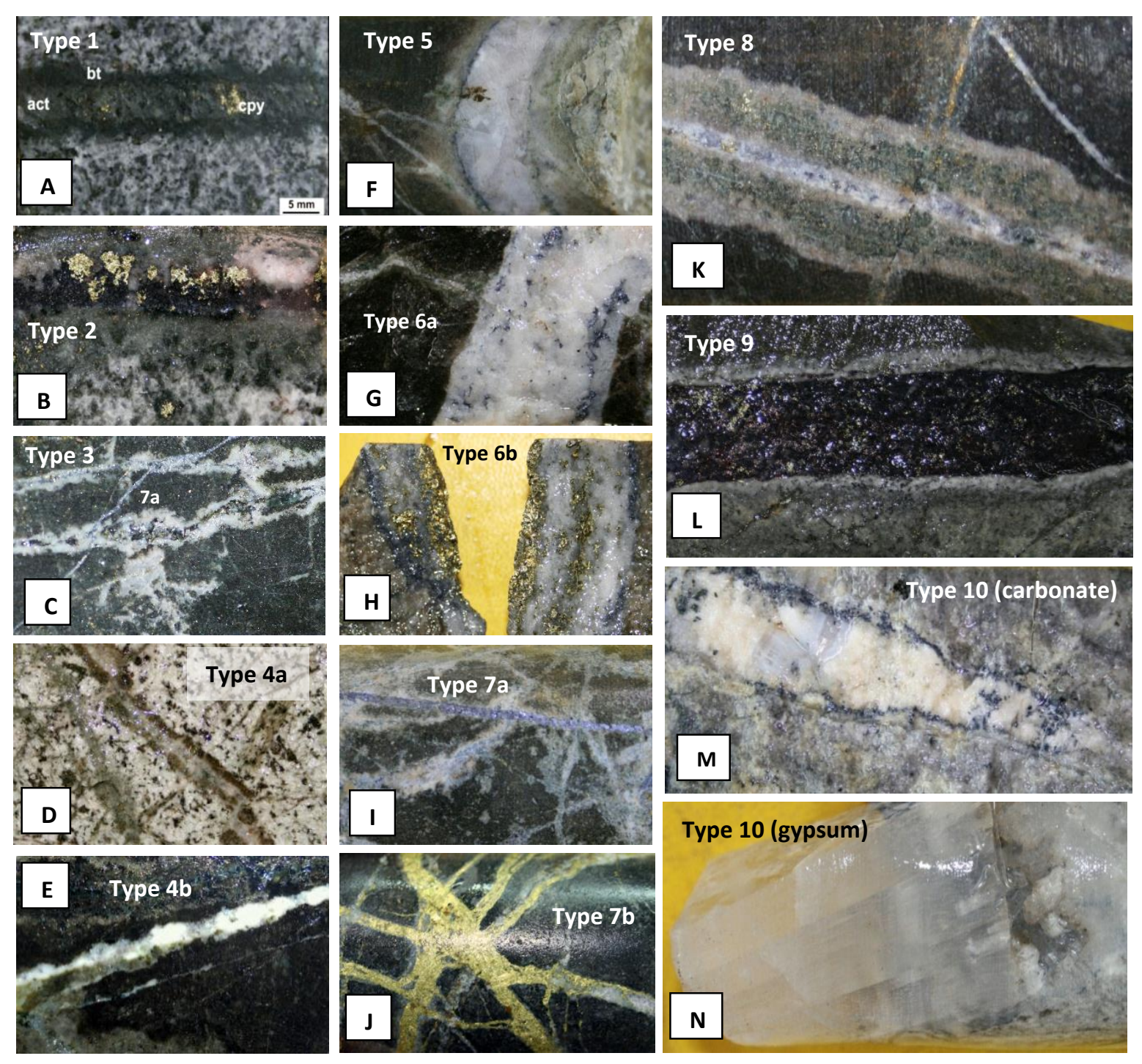


\section{Grade Distributions}

In order to identify the most important controls of Mo distribution and the extent of Mo-Cu decoupling at El Teniente, deposit geology (Fig. 2) was compared with combined Mo and Cu grade distribution data (courtesy of CODELCO Division El Teniente) for three mine levels [1890 m, Fig. 6; 2200 m, Fig. 7; and 2350 m above sea-level (asl), Fig. 8]. Due to sloping topography, the current land surface is $2300 \mathrm{~m}$ asl at the western margin of the deposit area and approximately $3300 \mathrm{~m}$ asl on the eastern margin. Morphological reconstruction of a nearby volcanic center (Rivera and Falcon, 1998), estimates of local exhumation rates (Skewes and Holmgren, 1993; Kurtz et al., 1997) and calculations of pressure using fluid inclusions (Cannell, 2004) indicate approximately $2000 \mathrm{~m}$ of erosion at El Teniente since approximately $5 \mathrm{Ma}$. Therefore, the deepest grade distribution slice examined is inferred to represent a depth of approximately $3 \mathrm{~km}$ below the paleosurface.

At the deepest mine level studied, Mo mineralization displays a close spatial association with the Northern, North Central and Central diorites (Fig. 6). Mineralization is abundant within and surrounding these diorites, with the highest grades observed at their contacts with the TMC. Copper grades also show a clear spatial relationship with these intrusions with the $1.0 \mathrm{wt} . \% \mathrm{Cu}$ contour surrounding all the diorite intrusions and enclosing zones of maximum Mo grade. High $\mathrm{Mo}$ and $\mathrm{Cu}$ grades also appear to show a relationship with igneous and anhydrite breccias surrounding the Northern Diorite and North Central Diorite and also to the south of the Braden Breccia pipe. Particularly high Mo:Cu ratios are found on the western and southern sides of the Braden Breccia pipe and proximal to the Southern Diorite. At this level, the center of the Braden Breccia pipe, the Teniente Dacite Porphyry and A-Porphyry all show relatively low Cu and Mo grades (Fig. 6).

At intermediate mine levels, the high grade Mo and $\mathrm{Cu}$ shells spatially associated with the Northern, North Central and Central diorites shift approximately $100 \mathrm{~m}$ to the west (Fig. 7) maintaining a similar separation to that observed at $1890 \mathrm{~m}$ asl. This is likely to be a manifestation of the orientation of the diorite pipes, which tilt slightly towards the northwest (e.g. Vry et al., 2010). The highest Mo grades are associated with the western and eastern rims of the Braden Breccia pipe with an additional Mo anomaly occurring within a tourmaline breccia south of the Braden Breccia pipe, which is cut by the southern tip of a northwest-trending latite dike. Highest $\mathrm{Cu}$ grades are associated with the southern tip of the North Central Diorite and the northern tip of the Central Diorite (Fig. $\mathrm{xx}$ ). Elevated Cu grades also occur at the margins of the Teniente Dacite Porphyry, in particular associated with a large anhydrite breccia body to the north of the Braden Breccia pipe where grades exceed $2 \mathrm{wt} . \%$. 


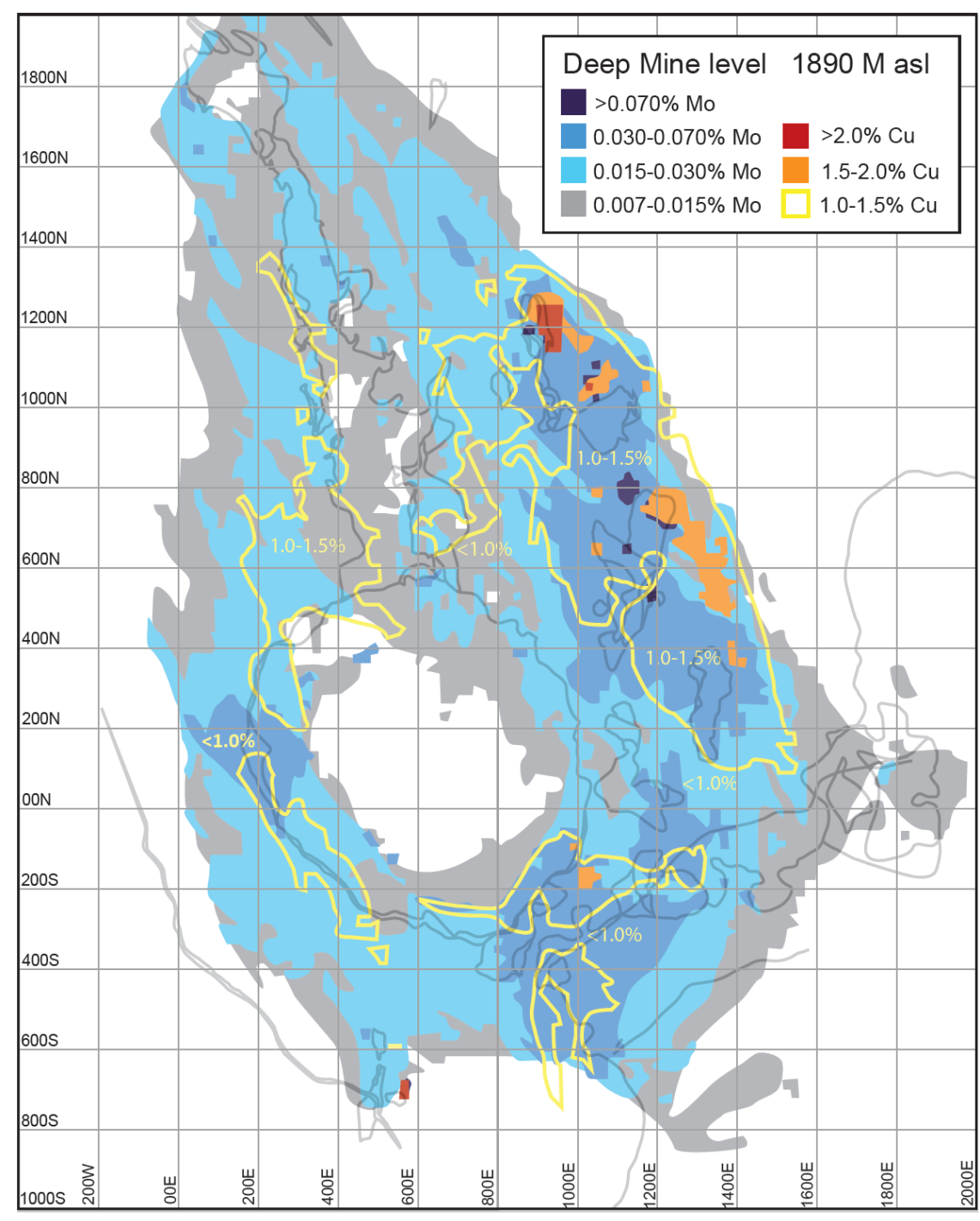

Fig. 6: Grade distribution map of Mo and $\mathrm{Cu}$ (wt.\%) at a deep mine level (1890 $\mathrm{m}$ asl). Outline map from Fig. 2 is superimposed to show the relationship between mineralization and geology. Original maps, Mo grades and $\mathrm{Cu}$ grades courtesy of CODELCO Division El Teniente.

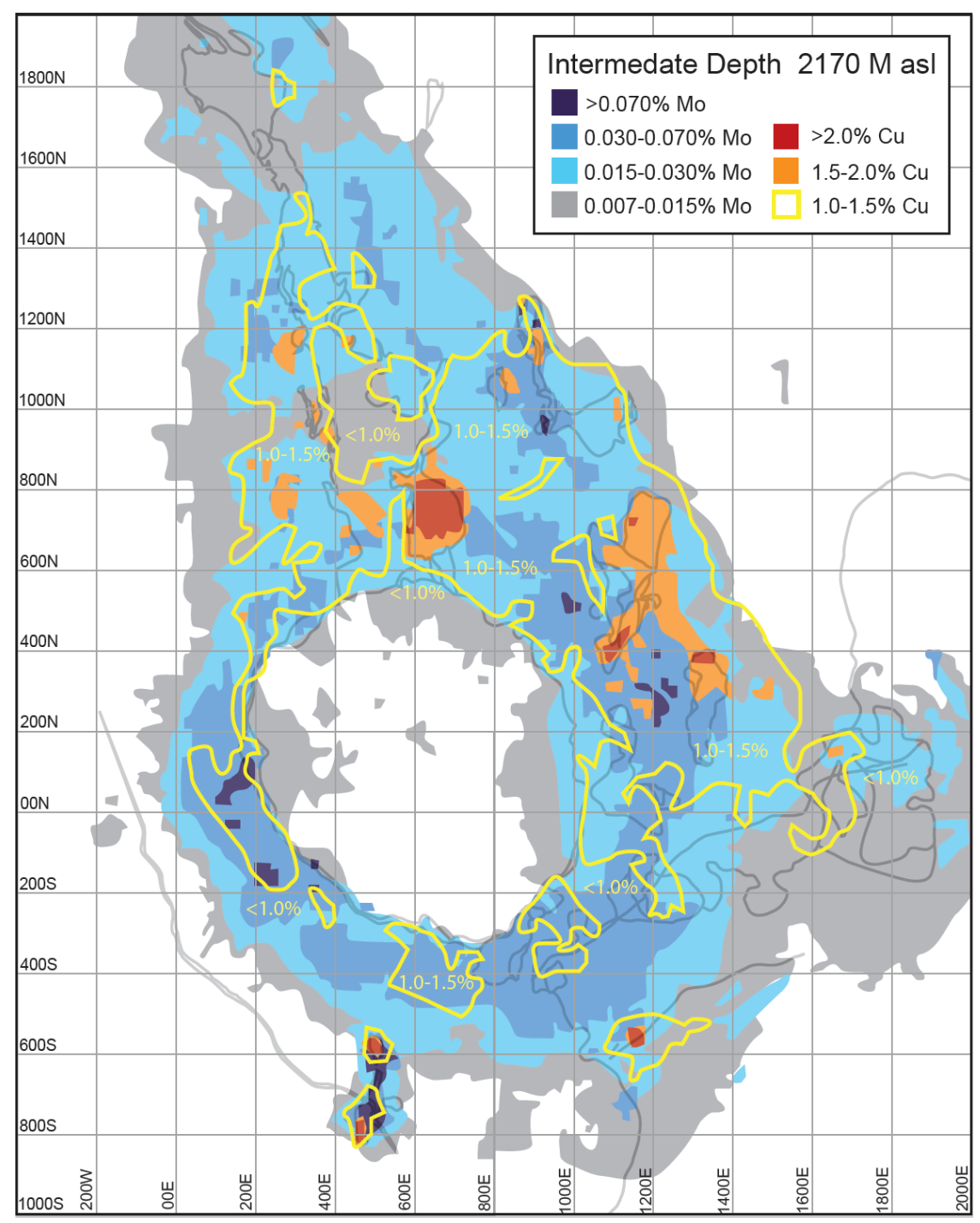

Fig. 7: Grade distribution map of Mo and $\mathrm{Cu}(w t . \%)$ at intermediate mine level ( $2170 \mathrm{~m}$ asl). Outline map from Fig. 2 is superimposed to show the relationship between mineralization and geology. Original maps, Mo grades and $\mathrm{Cu}$ grades courtesy of CODELCO Division El Teniente. 
At the shallowest mine level studied ( $2350 \mathrm{~m}$ asl), both $\mathrm{Mo}$ and $\mathrm{Cu}$ are concentrated within and surrounding the A-Porphyry, Southern Diorite, North Central Diorite and Northern Diorite (Fig. 8). Unlike $\mathrm{Cu}$, high grade Mo mineralization also occurs in a semi-continuous halo of $>0.03 \mathrm{wt} . \%$ approximately 100-250 m from the perimeter of the Braden Breccia pipe. This enriched halo appears to be a continuation of that seen at the intermediate mine level (Fig. 7) and occurs outboard of the marginal tourmaline breccias that surround the breccia pipe. High Mo grades are also observed in association with small tourmaline breccia bodies at the southern tip of the latite dyke southwest of the Braden Breccia pipe and overlying the Grueso Porphyry (Fig. 8). Zones of high Cu grade are found to the north of the Braden Breccia pipe and extend to the north and east where they display a spatial association with the North Central Diorite and the margins of the Teniente Dacite Porphyry. The Mo halo surrounding the Braden Breccia pipe is associated with dilution of Cu grades associated with the Teniente Dacite Porphyry margins (Fig. 8).

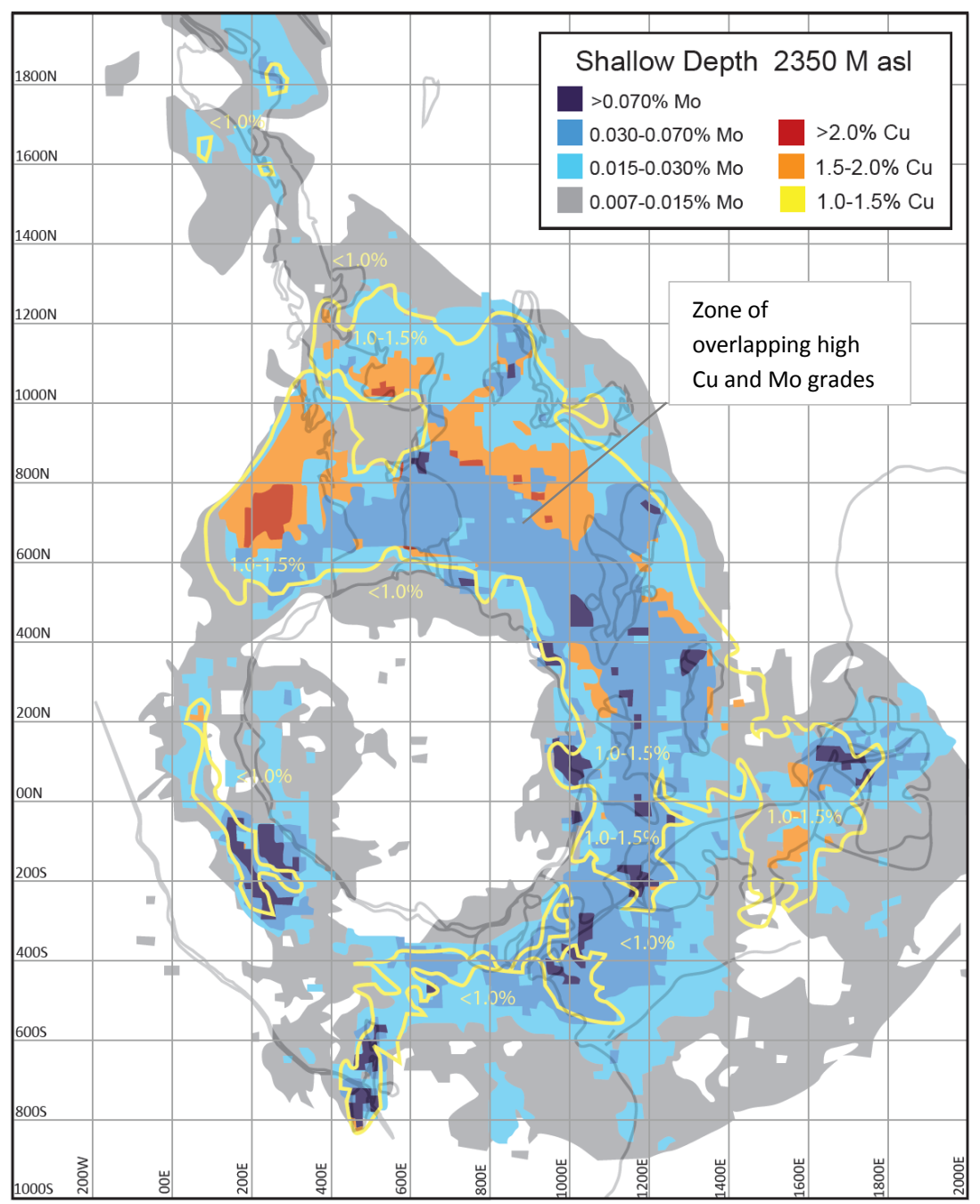

Fig. 8: Grade distribution map of $\mathrm{Mo}$ and $\mathrm{Cu}(\mathrm{wt} . \%)$ at a shallow mine level $(2350 \mathrm{~m}$ asl). Outline map from Fig. 2 is superimposed to show the relationship between mineralization and geology. Original maps, Mo grades and Cu grades courtesy of CODELCO Division EI Teniente. 


\section{Methodology}

\section{Drillcore Logging}

Fieldwork was completed at El Teniente in two visits in Oct - Nov 2011 and Sept - Oct 2012. Fourteen drillcores were studied in order to analyze mineralization and hydrothermal alteration assemblages associated with intrusions and breccias at various mine-levels (see Table 1; Fig. 2). Over 240 samples were collected for laboratory analysis. These included examples of each vein and breccia type hosted by different lithologies, samples suitable for fluid inclusion analysis, and wellconstrained, Mo-rich samples for Re-Os dating.

Table 1: Summary information for drillcores analyzed during this study.

\begin{tabular}{|c|c|c|c|c|c|c|c|}
\hline & Drillcore & Starting Coordinates & Azimuth & Inclination & $\begin{array}{l}\text { Meters } \\
\text { studied }\end{array}$ & $\begin{array}{c}\text { Elevation } \\
\text { m asl }\end{array}$ & Lithology \\
\hline \multirow{2}{*}{ T1 } & DDH 2371 & N 942.555 E 940.844 & $89.0^{\circ}$ & $-4^{\circ}$ & $0-200$ & 2055.34 & TMC-ND \\
\hline & DDH 2363 & N 942.041 E 921.751 & $270.6^{\circ}$ & $-6^{\circ}$ & $0-200$ & 2054.28 & ND-TMC \\
\hline \multirow{2}{*}{ T2 } & DDH 2215 & N 505.017 E 1115.823 & $90.0^{\circ}$ & $+15.3^{\circ}$ & $0-200$ & 1987.88 & TMC-NCD \\
\hline & DDH 2230 & N 505.062 E 1108.458 & $269.8^{\circ}$ & $-3.2^{\circ}$ & $0-200$ & 1986.40 & NCD-TMC \\
\hline T3 & DDH 2083 & N 199.930 E 1380.040 & 270.0 & $+2^{\circ}$ & $0-300$ & 2214.24 & TMC-CD-SD \\
\hline T4 & DDH 1888 & S 413.420 E 425.420 & $74.0^{\circ}$ & $-52^{\circ}$ & $0-300$ & 2283.21 & TMC \\
\hline \multicolumn{2}{|c|}{ DDH 1805} & N 602.511 E 1209.048 & Vertical & $-90^{\circ}$ & $0-533$ & 1984.84 & NCD-TMC \\
\hline \multicolumn{2}{|c|}{ DDH 1034} & N 619.285 E 1323.062 & $265^{\circ}$ & $-80^{\circ}$ & $0-990$ & 2286.64 & NCD-TMC \\
\hline \multicolumn{2}{|c|}{ DDH 2638} & N 1315.955 E 252.358 & $44.91^{\circ}$ & -54.80 & $0-300$ & 2166.72 & TMC-TDP \\
\hline \multicolumn{2}{|c|}{ DDH 1754} & N 318.659 E 933.357 & $87^{\circ}$ & -10.00 & $0-390$ & 2384.00 & TMC-CD \\
\hline \multicolumn{2}{|c|}{ DDH 2305} & N 36.786 E 1702.716 & $279.65^{\circ}$ & $-13.95^{\circ}$ & $0-300$ & 2322.62 & AP-TMC \\
\hline \multicolumn{2}{|c|}{ DDH 2661} & N 750.194 E 188.325 & $269.35^{\circ}$ & $-59.17^{\circ}$ & $60-360$ & 2164.83 & TMC-TDP \\
\hline \multicolumn{2}{|c|}{ DDH 2672} & S 775.516 E 565.298 & $270.67^{\circ}$ & $+28.80^{\circ}$ & $0-190$ & 2192.81 & TB-LD-TMC \\
\hline \multicolumn{2}{|c|}{ DDH 2716} & S 61.438 E 126.059 & $77.0^{\circ}$ & $+34.00^{\circ}$ & $0-120$ & 2356.23 & TMC-BB \\
\hline
\end{tabular}

Notes: For drillcore locations refer to Fig. 2. T1-T4 = Transects 1-4 used for vein distribution analysis. ND = Northern Diorite, NCD = North Central Diorite, $C D=$ Central Diorite, $S D=$ Southern Diorite, TDP = Teniente Dacite Porphyry, AP = A-Porphyry, TB = Tourmaline Breccia, LD = Latite Dike, BB = Braden Breccia pipe.

Based on Mo grade distribution maps, six drillcores were selected on which to complete detailed vein distribution analyses. These formed three, near-horizontal, E-W trending transects that cut the diorites at various depths (transects 1-3) and a final transect (transect 4) that cuts the Morich halo and Teniente Dacite Porphyry to the south of the Braden Breccia pipe (Fig. 2). Detailed notes on lithology, alteration and sulfide abundances were taken along each transect and the total number of veins of each type was recorded for each meter interval following the vein classification of Vry et al. (2010). The lack of reverse cross-cutting veins and breccia relationships surrounding these intrusions (Vry et al., 2010) suggest that the main mineralization stage vein halos in transects 
1-4 are not likely to be formed by the overprinting of veins related to multiple mineralization events. This meant that the vein distribution analysis should either record overall vein abundances for a deposit-wide evolution in vein type or will allow for the study of vein abundances surrounding essentially isolated mineralized centers.

Near horizontal transects were selected in order to intersect veins surrounding the diorites and Braden Breccia Pipe that were previously described as being predominantly vertical or subvertical (e.g. Cannell et al., 2005). The majority of veins present in transects 1-4 cut the drillcores at near-perpendicular angles, rarely extending for lengths of $>6 \mathrm{~cm}$, and are therefore predominantly oriented roughly N-S. In the rare cases where veins ran along the drillcore for $>10 \mathrm{~cm}$, or branched into two separate veins each with lengths of $>3 \mathrm{~cm}$, they were recorded as two veins based on the assumption that they would exert a higher than normal control on $\mathrm{Mo}$ and $\mathrm{Cu}$ grades in their drillcore interval. Composite veins were counted as two separate veins, provided the separate vein generations could be identified. If this was not possible, the vein was classified by its predominant mineralogy. Due to the relatively uniform thickness of each vein type (discussed in subsequent sections) and the fact that the thickest veins are typically gangue-dominated (e.g. early barren quartz and anhydrite veins and late gypsum veins), vein width was not taken into account. However, notes were made when unusually large, sulfide-rich veins were encountered. Veinlets with widths of $<1 \mathrm{~mm}$ were not recorded. Results were compared against average Mo and $\mathrm{Cu}$ grades provided by CODELCO División El Teniente. Average grades are reported for six meter drillcore intervals along transects 1-2 whereas grades are given for 20 foot intervals along the earlier studied drillcores in transects 3-4.

In order to investigate the distribution of Mo with depth, two drillcores (DDH 1805 and DDH 1034) were selected in order to provide a near-vertical section proximal to the North Central Diorite (Fig. 2, Table 1). These extended down to an elevation of $1300 \mathrm{~m}$ asl, representing a vertical profile of approximately one kilometer that extends down to an estimated paleodepth of 3.5-4.0 km. Six additional drillcores were studied to enable a deposit-wide analysis of molybdenite mineralization by assessing cross-cutting relationships between vein types, breccias and intrusions and their association with Mo or $\mathrm{Cu}$ anomalies (Table 1).

\section{Petrography}

Representative and well-constrained vein and breccia samples from several intrusions and the TMC were selected for petrographic analysis. These samples were obtained from a range of 
depths and had highly contrasting sulfide abundances and associated alteration. Sixty polished thin sections were prepared with thicknesses of 32-150 $\mu \mathrm{m}$. All samples were studied using conventional transmitted light petrography to confirm vein/breccia classifications and by reflected light microscopy in order to identify sulfides present, their relative abundances and their timing relationships.

\section{Geochronology}

Unlike the other dating techniques used at El Teniente, which may be susceptible to the effects of hydrothermal overprinting, the Re-Os isotopic system displays closed behavior during post mineralization alteration, ductile deformation and regional metamorphism (e.g. Stein et al., 1998; Selby and Creaser, 2001; Stein and Bingen, 2002 Bingen and Stein, 2003; Ootes et al., 2007; Bingen et al., 2008; Lawley and Selby, 2012). This, combined with the fact that molybdenite is the third most abundant ore mineral at El Teniente (Camus, 1975) makes it a suitable technique for dating mineralization. Twenty samples were initially selected for Re-Os molybdenite dating based on their vein/breccia type, sample depth and geographic locations. Large composite veins and overprinted veins were avoided so that accurate age determinations could be made for single molybdenite generations in each vein. Consistent with their premineralization stage classification, reflected light analysis revealed that the amount of molybdenite in all selected type 3-4b veins was either insufficient for dating or it was the result of overprinting by later vein generations. As a result, no samples from this paragenetic stage were dated in this study.

Eleven samples were selected for Re-Os molybdenite dating that comprised 7 main mineralization stage samples and 4 samples from the late mineralization stage. Vein samples ranging from type 6a to type 10 were obtained from proximal to the Central Diorite and Southern Diorite in order to study the temporal evolution of veins within a single part of the deposit (Fig. 2). Two type $6 a$ vein samples with a difference in elevation of approximately $550 \mathrm{~m}$ were selected proximal to the North Central Diorite in order to assess the relationship between depth and timing of molybdenite mineralization (1034-837.0, 2215-119.9). Additional samples analyzed included a molybdenite-rich tourmaline breccia from the western rim of the Braden Breccia pipe (2716-8.0) and a type $6 \mathrm{~b}$ vein associated with the southern tip of the Teniente Dacite Porphyry (1888-133.8). The final sample analyzed was a sample from the B-Fault, an anastomosing NW-trending fault zone that coincides with a significant Mo anomaly to the east of the Braden Breccia pipe (Figs. 2, 8). Mine geologists report evidence for right-lateral, strike-slip displacement along this fault zone, which has created slickensides on the contained molybdenite. Although this indicates displacement following 
molybdenite mineralization, the timing of Mo introduction remains untested. This information can be used to assess the relationships between fault activation, intrusion emplacement and crystallization and mineralization.

All samples were prepared and analyzed at the University of Alberta Radiogenic Isotope Facility, Canada, using the method of Selby and Creaser (2001, 2004). Veins and breccia zones of interest were cut out of each sample to create molybdenite-rich specimens with weights of $<20 \mathrm{~g}$. Cut samples were crushed separately using a porcelain disk mill, collecting the fraction that passed through a 200-70 mesh sieve. Molybdenite was then separated using a Frantz isodynamic magnetic separator and heavy liquid (methylene lodide). Due to the low abundance of molybdenite in sample 2083-184.1, molybdenite was separated using the hydrofluoric acid (HF) chemical separation technique of Lawley and Selby (2012) to maximize recovery. Lawley and Selby (2012) showed that this technique does not affect the Re and Os isotope composition of molybdenite and can be used to obtain accurate and reproducible age determinations for ultrafine molybdenite.

Previous Re-Os studies have shown that analyzing large amounts of separated or handpicked molybdenite (i.e. $10 \mathrm{mg}$ ) or small aliquots of separated molybdenite $(<1 \mathrm{mg})$ can both yield dates that significantly deviate from "true" sample ages (Stein et al., 1998, 2001; Creaser and Selby, 2002). In order to avoid anomalous results produced by the sampling of multiple generations of molybdenite, relatively small aliquots of molybdenite with weights of approximately $1.2 \mathrm{mg}$ were separated. These were accurately weighed and dissolved together with a known amount of "mixeddouble" spike $\left({ }^{188} \mathrm{Os}+{ }^{190} \mathrm{Os}+{ }^{185} \mathrm{Re}\right.$; Markey et al., 2007) in a thick-walled Carius tube. Os and Re were separated using a combination of solvent extraction, microdistillation and anion chromatographic methods and analyzed by N-TIMS using a Thermo Triton mass spectrometer and Faraday Collectors. Previous studies have shown this to be an effective technique for deriving highly precise, accurate and reproducible molybdenite ages (Selby and Creaser, 2001, 2004; Stein et al., 2001). Procedural blanks are less than $2 \mathrm{pg}$ for Re and $3 \mathrm{pg}$ for Os, and model ages were calculated using the ${ }^{187} \mathrm{Re}$ decay constant of $1.666 \times 10^{-11} \mathrm{a}^{-1}$ (Smoliar et al., 1996). Uncertainty in the Re-Os model ages includes uncertainty in the ${ }^{187} \mathrm{Re}$ decay constant, Re and Os concentrations as a result of weighing uncertainties (spikes and samples), spike calibration and mass spectrometry analytical uncertainties. All age uncertainties are reported at the $2 \sigma$ level in the results section. Three samples were selected for replicate runs using the same mineral separate in order to assess the accuracy and reproducibility of results and confirm that these samples consisted of a single generation of molybdenite. 


\section{Breccia Distribution and Petrography}

Seven breccia types were observed in this study (igneous-, biotite-, anhydrite-, quartz-, tourmaline-, anhydrite-carbonate \pm gypsum-cemented, and rock flour breccias). These are spatially associated with different intrusions and contain highly variable sulfide abundances as summarized in Table 2. Consistent with their interpreted premineralization timing (Cannell et al., 2005; Vry et al., 2010), Mo and $\mathrm{Cu}$-sulfides are rare in igneous and biotite breccias. However, all other breccias contain highly variable, and often appreciable, amounts of $\mathrm{Cu}-(5-40 \%)$ and Mo-sulfides (5-20\%). Mineralization in anhydrite breccias is often concentrated where later Mo- and Cu-rich veins cut the breccia matrix. However, in most cases, intergrown sulfide and gangue minerals are present in their matrices and so mineralization is interpreted to have been synchronous with formation.

In transects 1-4, igneous-, anhydrite-, tourmaline- and anhydrite-carbonate \pm gypsumcemented breccias were observed. Anhydrite breccias commonly form a shell surrounding the diorite pipes and contain elevated average $\mathrm{Mo}$ and $\mathrm{Cu}$ grades in transects 1, 3 and 4 (Table 3A-B). However, average grades were lower in intervals of anhydrite breccia in transect 2 , reflecting the locally variable sulfide abundances within their cements (Table 2).

Tourmaline- and anhydrite-carbonate \pm gypsum-cemented breccias are abundant at shallow mine levels, where they cut all intrusions and truncate type 8 veins (e.g. Fig. 9A). Mo-rich tourmaline breccias are particularly abundant surrounding the Braden Breccia pipe, where six meter drillcore intersections have average Mo grades of up to $0.35 \mathrm{wt. \%}$ (DDH 2716). In these breccias fine-grained Mo often occurs throughout the tourmaline-dominated matrix. Mo-poor tourmaline breccias were also observed. These principally occur at deeper mine levels and in distal positions relative to the Braden Breccia pipe. Intersections of tourmaline breccia are generally Cu-poor (Table 3B), although sections of chalcopyrite- and pyrite-rich tourmaline breccias were observed in transect 1 , and in drillcores DDH 2716, 1888 and 2672. Anhydrite-carbonate \pm gypsum-cemented breccias are almost always enriched in Mo (e.g. Table 3A). Molybdenite is predominantly concentrated around clast margins where it commonly occurs as large bladed crystals. Cu grades are generally low in anhydritecarbonate \pm gypsum-cemented breccias (Table 3B). However, some shallow-level anhydrite-rich examples contain significant chalcopyrite and bornite infill, accounting for the highly variable average $\mathrm{Cu}$ grades recorded (0.98-1.93 wt.\%) for the transects studied (Table 3B). In some cases CUsulfide mineralization occurs alongside significant molybdenite in the breccia matrix (e.g. Fig. 9B-C). This suggests that some late stage pulses of both Mo and Cu-rich hydrothermal fluids occurred. 
Table 2: Summary of the observed compositions, occurrences and key petrographic features of the seven different breccia types observed during drillcore logging.

\begin{tabular}{|c|c|c|c|}
\hline Breccia & Composition & Occurrence & Sulfides \\
\hline \multirow[b]{2}{*}{ Igneous } & $\begin{array}{l}\text { Plag phenocrysts } \\
\text { +bt-qz-anh }\end{array}$ & \multirow{2}{*}{$\begin{array}{l}\text { - Second most common breccia type observed. } \\
\text { - Occur surrounding every intrusion at all mine } \\
\text { levels suggesting that they are linked to the } \\
\text { emplacement of each intrusion } \\
\text { - Cut by all vein stages from } 3 \text { onwards and all } \\
\text { other breccias }\end{array}$} & \multirow{2}{*}{$\begin{array}{l}\text { - Typically contain }<1 \% \text { mo and }<2 \% \\
\text { cpy, }<1 \% \text { py and no bo } \\
\text { - Sulfides interpreted to be the } \\
\text { result of later vein stages and } \\
\text { disseminations related to the main } \\
\text { and late mineralization stages }\end{array}$} \\
\hline & $\begin{array}{c}\text { Clasts }= \\
\text { Predominantly TMC } \pm \\
\text { Sewell Quartz Diorite, } \\
\text { A-Porphyry }\end{array}$ & & \\
\hline \multirow[b]{2}{*}{ Biotite } & $\begin{array}{l}\text { Plag phenocrysts } \\
\text { +bt-qz-anh }\end{array}$ & \multirow{2}{*}{$\begin{array}{l}\text { - Only observed proximal to the A-Porphyry and } \\
\text { SQD in DDH } 2305 \text {. None observed in other } \\
\text { intrusions } \\
\text { - Sample bt bx } 1 \text { was a supplementary sample } \\
\text { obtained from a deep mine level where bt } \\
\text { breccia preservation is inferred to be better }\end{array}$} & \multirow{2}{*}{$\begin{array}{l}\text { - Minor cpy <3\% observed in one } \\
\text { sample (Bt Bx 1) } \\
\text { Opaque daughter minerals (cpy?) } \\
\text { observed in large fluid inclusions }\end{array}$} \\
\hline & $\begin{array}{c}\text { Clasts }= \\
\text { Predominantly TMC } \pm \\
\text { SQD }\end{array}$ & & \\
\hline \multirow[b]{2}{*}{ Anhydrite } & $\begin{array}{l}\text { Plag phenocrysts } \\
\text { +bt-qz-anh }\end{array}$ & \multirow{2}{*}{$\begin{array}{l}\text { - Most frequently observed breccia type during } \\
\text { this study } \\
\text { - Observed surrounding the A-Porphyry, diorites } \\
\text { and Teniente Dacite Porphyry. Notable sulfide- } \\
\text { rich examples recorded proximal to the A- } \\
\text { Porphyry, North Central Diorite, Southern } \\
\text { Diorite and to the south of the Braden pipe }\end{array}$} & \multirow{2}{*}{$\begin{array}{l}\text { - Highly variable. Typically }<5 \% \text { mo, } \\
<10 \% \text { cpy, }<2 \% \text { bo, }<5 \% \text { py } \\
\text { - Contain up to } 40 \% \text { mo, typically } \\
\text { found at the clast-matrix contacts, } \\
\text { - Contain up to } 50 \% \text { blocky cpy } \\
\text { found throughout anh cement }\end{array}$} \\
\hline & $\begin{array}{c}\text { Clasts = } \\
\text { Predominantly TMC + } \\
\text { A-Porphyry + Sewell } \\
\text { Quartz Diorite }\end{array}$ & & \\
\hline \multirow[b]{2}{*}{ Quartz } & $\begin{array}{l}\text { qz with minor anh } \\
\text { and } K-f s p \text { in cases }\end{array}$ & \multirow{2}{*}{$\begin{array}{l}\text { Rare occurrences observed at the contacts of } \\
\text { the diorites in areas of intense qz stockwork } \\
\text { veining. Best example observed proximal to the } \\
\text { North Central Diorite } \\
\text { - Evidence that quartz is replaced anh cement, } \\
\text { possibly during the type } 6 \text { vein stage }\end{array}$} & \multirow{2}{*}{$\begin{array}{l}\text { - Typically contain minor mo } 5-10 \% \\
\text { (e.g. Fig. } 4 \text { E), usually found at } \\
\text { cement-clast contacts } \\
\text { - Minor cpy }<5 \% \text { in all samples } \\
\text { observed. }\end{array}$} \\
\hline & $\begin{array}{c}\text { Clasts = } \\
\text { Predominantly TMC } \\
\text { and altered diorite }\end{array}$ & & \\
\hline \multirow[b]{2}{*}{ Tourmaline } & $\begin{array}{l}\text { Tour } \pm \text { anh, often with } \\
\text { abundant mo }\end{array}$ & \multirow{2}{*}{$\begin{array}{l}\text { - Observed surrounding the Braden Breccia pipe } \\
\text { in DDH } 2716, \mathrm{DDH} 2083 \text { and DDH } 1888 \text { as well } \\
\text { as cut by the latite dike to the south of the } \\
\text { Braden pipe (DDH 2672) } \\
\text { - Crosscut the Teniente Dacite Porphyry and } \\
\text { diorites and are cut by the Braden pipe }\end{array}$} & \multirow{2}{*}{$\begin{array}{l}\text { - Highly variable with examples } \\
\text { containing } 0-70 \% \text { mo in cement } \\
\text { - Several examples contain } \\
\text { abundant cpy and py, possibly } \\
\text { representing sulfide zonation } \\
\text { surrounding the Braden pipe }\end{array}$} \\
\hline & $\begin{array}{c}\text { Clasts }=\text { Teniente } \\
\text { Dacite Porphyry + } \\
\text { TMC } \pm \text { diorites }\end{array}$ & & \\
\hline \multirow{2}{*}{$\begin{array}{l}\text { Anhydrite- } \\
\text { carbonate- } \\
\text { 土gysum }\end{array}$} & $\begin{array}{l}\text { anh+cb } \pm \text { gyp } \\
\pm \text { sulfosalts }\end{array}$ & \multirow{2}{*}{$\begin{array}{l}\text { Observed crosscutting the diorites and Teniente } \\
\text { Dacite Porphyry In most drillcores. } \\
\text { Display an apparent spatial relationship with } \\
\text { the presence of NW-trending and concentric } \\
\text { faults surrounding the Braden pipe (see Fig. 2). }\end{array}$} & \multirow{2}{*}{$\begin{array}{l}\text { - Typically contain abundant mo (5- } \\
50 \% \text { and bo (5-20\%), which appear } \\
\text { to be coprecipitated } \\
\text { - cpy }<10 \% \text { in most samples } \\
\text { - Minor sulfosalts in several samples } \\
\text { (tennantite+enargite) }\end{array}$} \\
\hline & $\begin{array}{c}\text { Clasts = Teniente } \\
\text { Dacite Porphyry + } \\
\text { TMC + diorites }\end{array}$ & & \\
\hline \multirow[b]{2}{*}{ Rock flour } & $\begin{array}{l}\text { Plag phenocrysts } \\
\text { +bt-qz-anh }\end{array}$ & \multirow{2}{*}{$\begin{array}{l}\text { - Rock flour breccia composes the central portion } \\
\text { of the Braden pipe surrounded by the marginal } \\
\text { tourmaline breccias. } \\
\text { - Recorded in drillcores DDH } 2716 \text { and at the } \\
\text { start of DDH } 1754 \\
\text { - Crosscuts the Teniente Dacite Porphyry and all } \\
\text { other breccia types }\end{array}$} & \multirow{2}{*}{$\begin{array}{l}\text { - Shattered fragments of cpy and py } \\
\text { with minor mo and bo in matrix } \\
\text { - Cpy-rich clasts of Teniente Dacite } \\
\text { Porphyry and diorite truncated by } \\
\text { breccia matrix }\end{array}$} \\
\hline & $\begin{array}{l}\text { Clasts = All intrusions, } \\
\text { TMC + brecciated tour } \\
\text { and sulfides (cpy) }\end{array}$ & & \\
\hline
\end{tabular}

Notes: Breccia names are derived from the primary components of cement/matrix. These are listed in an inferred idealized chronologic order proposed by Vry et al. (2010). Mineral abbreviations: refer to Fig. 5. 
Table 3: Summary of grade data for drillcores in transects 1-4 (T1-4) showing average Mo (Table A) and Cu grades (Table B) for each host lithology.

\begin{tabular}{|c|c|c|c|c|c|c|c|c|c|c|c|}
\hline \multicolumn{2}{|c|}{ A. MO GRADES } & \multicolumn{2}{|c|}{ Veins } & \multicolumn{6}{c|}{ Grades } & \multicolumn{6}{c|}{ Lithology } \\
\hline \multirow{2}{*}{ T. } & Drillcore & $\begin{array}{c}\text { Common } \\
\text { Veins }\end{array}$ & Veins/m & $\begin{array}{c}\text { Average } \\
\text { Mo }\end{array}$ & TMC & DIO & $\begin{array}{c}\text { Teniente } \\
\text { Dacite } \\
\text { Porphyry }\end{array}$ & Ign Bx & $\begin{array}{c}\text { Anh } \\
\text { Bx }\end{array}$ & $\begin{array}{c}\text { Tour } \\
\text { Bx }\end{array}$ & $\begin{array}{c}\text { A-C-G } \\
\text { Bx }\end{array}$ \\
\hline \multirow{2}{*}{ T1 } & DDH 2371 & $6 \mathrm{a}>8>6 \mathrm{~b}$ & 16.8 & $\mathbf{0 . 0 3 9}$ & 0.055 & 0.032 & & 0.037 & & & 0.085 \\
\cline { 2 - 13 } & DDH 2363 & $6 \mathrm{~b}>8>6 \mathrm{a}$ & 21.9 & $\mathbf{0 . 0 2 4}$ & 0.023 & 0.024 & & & 0.043 & 0.012 & 0.078 \\
\hline \multirow{2}{*}{ T2 } & DDH 2215 & $6 \mathrm{a}>6 \mathrm{~b}>8$ & 17.4 & $\mathbf{0 . 0 3 7}$ & 0.037 & 0.039 & & 0.029 & & & 0.074 \\
\cline { 2 - 12 } & DDH 2230 & $6 \mathrm{a}>6 \mathrm{~b}>8$ & 22.5 & $\mathbf{0 . 0 3 0}$ & 0.030 & 0.027 & & & 0.021 & & 0.064 \\
\hline T3 & DDH 2083 & $8>6 \mathrm{a}>6 \mathrm{~b}$ & 26.7 & $\mathbf{0 . 0 4 5}$ & 0.039 & 0.045 & & 0.052 & 0.049 & 0.075 & 0.071 \\
\hline T4 & DDH 1888 & $9>8>6 \mathrm{a}$ & 33.3 & $\mathbf{0 . 0 4 7}$ & 0.040 & & 0.024 & & 0.071 & 0.105 & 0.072 \\
\hline \multicolumn{2}{|c|}{ Average all } & & 23.1 & $\mathbf{0 . 0 3 7}$ & $\mathbf{0 . 0 3 7}$ & $\mathbf{0 . 0 3 4}$ & $\mathbf{0 . 0 2 4}$ & $\mathbf{0 . 0 3 9}$ & $\mathbf{0 . 0 4 6}$ & $\mathbf{0 . 0 6 4}$ & $\mathbf{0 . 0 7 4}$ \\
\hline
\end{tabular}

\begin{tabular}{|c|c|c|c|c|c|c|c|c|c|c|c|}
\hline \multicolumn{2}{|c|}{ B. CU GRADES } & \multicolumn{2}{|c|}{ Veins } & \multirow{2}{*}{$\begin{array}{c}\text { Grades } \\
\begin{array}{c}\text { Average } \\
\mathrm{Cu}\end{array}\end{array}$} & \multicolumn{7}{|c|}{ Lithology } \\
\hline T. & Drillcore & $\begin{array}{c}\text { Common } \\
\text { Veins }\end{array}$ & Veins/m & & TMC & DIO & $\begin{array}{l}\text { Teniente } \\
\text { Dacite } \\
\text { Porphyry }\end{array}$ & $\operatorname{Ign} B x$ & $\begin{array}{c}\text { Anh } \\
\text { Bx }\end{array}$ & $\begin{array}{l}\text { Tour } \\
\text { Bx }\end{array}$ & $\begin{array}{c}\text { A-C-G } \\
\text { Bx }\end{array}$ \\
\hline \multirow{2}{*}{$\mathrm{T} 1$} & DDH 2371 & $6 a>8>6 b$ & 16.8 & 1.13 & 1.36 & 1.04 & & 1.13 & & & 1.21 \\
\hline & DDH 2363 & $6 b>8>6 a$ & 21.9 & 1.19 & 1.20 & 1.32 & & & 1.23 & 1.48 & 1.06 \\
\hline \multirow{2}{*}{ T2 } & DDH 2215 & $6 a>6 b>8$ & 17.4 & 1.20 & 1.33 & 0.86 & & 1.17 & & & 1.93 \\
\hline & DDH 2230 & $6 a>6 b>8$ & 22.5 & 0.92 & 0.92 & 0.63 & & & 0.88 & & 1.52 \\
\hline T3 & DDH 2083 & $8>6 a>6 b$ & 26.7 & 1.27 & 1.24 & 1.27 & & 1.66 & 1.52 & 0.95 & 1.34 \\
\hline T4 & DDH 1888 & $9>8>6 a$ & 33.3 & 0.99 & 0.98 & & 0.85 & & 1.39 & 0.93 & 0.98 \\
\hline \multicolumn{2}{|c|}{ Average all } & & 23.1 & 1.12 & 1.12 & 1.03 & 0.85 & 1.32 & 1.26 & 1.12 & 1.34 \\
\hline
\end{tabular}

Notes: Common veins $=$ three most common vein types recorded. $\mathrm{T}$. = Transect, $\mathrm{DIO}=$ Diorite, $\mathrm{Bx}=\mathrm{Breccia}$, A-C-G = anhydrite-carbonate \pm gypsum breccias. Grade data provided by CODELCO Division El Teniente.

Fig. 9 (next page): Sample photographs and cross-polarized and reflected light photomicrographs of sulfides in different breccias and vein stages. (A) Teniente Dacite Porphyry clast containing chalcopyrite-bearing type 8 veins being truncated by a tourmaline breccia on the western margin of the Braden Breccia pipe (271651.0). (B) Anhydrite-carbonate breccia containing bornite, chalcopyrite and molybdenite (2716-16.2). (C) Late stage breccia with molybdenite, chalcopyrite and pyrite cement (2672-238.0). (D) Cross-polarized light photomicrograph of elongate molybdenite crystals developed along the border of a type 5 vein in the TMC (2406-14). (E-G) Type examples of $6 \mathrm{~b}$ veins that contain abundant molybdenite. (E) Type $6 \mathrm{~b}$ vein in which molybdenite is overprinted by chalcopyrite at the vein center (2083-136.6). (F) Type 6b vein in which molybdenite is deposited at the vein edges and contains later quartz-chalcopyrite mineralization at the vein center (1754-258.3). (G) Composite type $6 \mathrm{~b}$ vein formed by the overprinting of a type 6a vein by a series of anastomosing type 7b chalcopyrite veins (2371-183.25). (H) Reflected light photomicrograph of chalcopyrite overprinting molybdenite in the type $6 \mathrm{~b}$ vein shown in photograph $\mathrm{G}$. Chalcopyrite veinlets truncate tabular molybdenite crystals and is also present in microfractures that cut molybdenite (I) Photograph showing the transition within a single vein from a type 6 a vein to a type 7a molybdenite vein in the A-Porphyry halo (2305-81.9-82.2). (J-K) Reflected light photomicrographs of a type 8 vein proximal to the Teniente Dacite Porphyry (2661-174.7), containing platy molybdenite $(\mathrm{J})$ and compositionally zoned quartz-molybdenite sections surrounded by bornite that is truncated by chalcopyrite and overprinted by chalcopyrite veinlets (K). (L) Composite transmitted and reflected light photomicrograph of abundant molybdenite associated with the edge of a type 9 vein to the east of the Braden Breccia pipe. Most of the vein is composed of anhydrite with isolated radiating fans of tourmaline (1754-226.5). (M) Cross-cutting relationships showing a type 8 vein being cut by two type 9 veins, all of which are overprinted by a type 10 carbonate-gypsum vein (2672-163.0). (N) Cross-polarized light photomicrograph of a type 10 vein containing abundant carbonate and anhydrite overprinting molybdenite at the vein edges (1754-226.5). Straight gangue mineral crystal edges clearly overgrow the finer molybdenite and isolated fragments of molybdenite also occur within the gangue mineralization. Scale bars in photographs $=1 \mathrm{~cm}$; in photomicrographs $=1 \mathrm{~mm}$. 

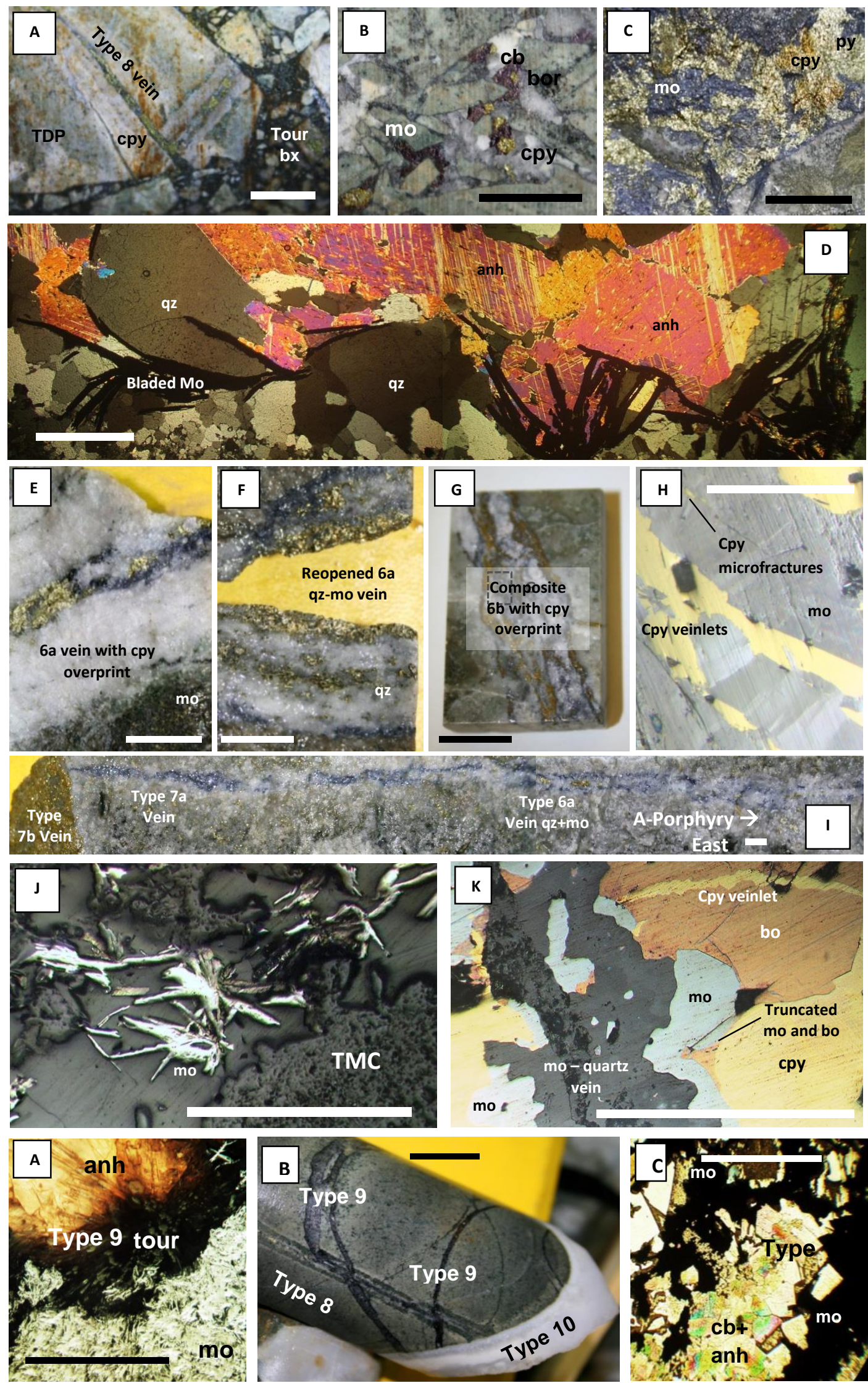


\section{Vein Distribution and Petrography}

The abundance and distribution of each vein type and their typical sulfide associations are summarized in Table 4. The vein distribution analysis recorded a total of 33,723 veins at an overall average frequency of $\sim 24$ veins per meter in transects $1-4$. Nearly $80 \%$ of veins were related to the main mineralization stage, with approximately $10 \%$ belonging to each of the premineralization and late mineralization stages. Abundant sulfide mineralization was observed in every vein stage with the exception of type 1 veins (Table 4). Of these, eight vein types $(3,5,6 a, 6 b 7 a, 7 b, 8,9$ and 10) commonly contain molybdenite and chalcopyrite that is observable without the use of a hand lens. Although often present in the same veins, evidence for the apparent co-precipitation of $\mathrm{Mo}$ and $\mathrm{Cu}$ was rarely observed. Thin section analysis reveals that molybdenite typically occurs on separate vein growth zones to chalcopyrite and bornite or is overprinted or truncated by later Cu-sulfides.

Total vein abundance is generally higher at shallower mine levels (e.g. Table 3A), largely due to increases in type $7 \mathrm{~b}-10$ vein frequency (Fig. 10). No vein type displays a clear increased abundance at deep mine levels, although the relative proportion of molybdenite-rich type $6 \mathrm{a}$ and $7 \mathrm{a}$ veins generally increases with depth in the two deepest drillcores studied (DDH 1805 and 1034). Vein frequencies are lower within the finger porphyries than within the mafic complex rocks immediately surrounding them. For example, an average vein frequency of 16.31 veins/meter was recorded for the Northern Diorite in transect 1, whereas the TMC exhibits a frequency of 21.96 veins/meter. This is largely due to pronounced decreases in the abundances of type 3 and 8 veins within the finger porphyries. 
Table 4: Summary of the mineralogy, occurrences and typical sulfide abundances of vein types observed in the 15 studied drillcores displayed in Fig. 2.

\begin{tabular}{|c|c|c|c|c|}
\hline Vein & Mineralogy & Occurrences & $\mathbf{N}$ & Sulfides \\
\hline \multirow{2}{*}{1} & bt-act \pm (chl-cpy) & \multirow{2}{*}{$\begin{array}{l}\text { - No veins observed during study } \\
\text { - Rare occurrences at deep mine levels associated with the Sewell } \\
\text { Quartz Diorite and A-Porphyry (Vry et al., 2010) }\end{array}$} & \multirow{2}{*}{$\begin{array}{c}0 \\
(0 \%) \\
\end{array}$} & \multirow{2}{*}{$\begin{array}{l}\text { - None observed during this } \\
\text { study }\end{array}$} \\
\hline & bt halo & & & \\
\hline \multirow{2}{*}{2} & $\begin{array}{l}\text { mag } \pm q z-a n h-(c p y- \\
\text { py) }\end{array}$ & \multirow{2}{*}{$\begin{array}{l}\text { - Preserved at depth and present as pervasive magnetic patches } \\
\text { at shallow mine levels }(>2200) \text { in the TMC } \\
\text { - Typical thicknesses of } 5-10 \mathrm{~mm} \\
\text { - Rare occurrences in the A-Porphyry (e.g. Fig. 5B) and diorites }\end{array}$} & \multirow{2}{*}{$\begin{array}{c}113 \\
(0.4 \%)\end{array}$} & \multirow{2}{*}{$\begin{array}{l}\text { - Minor mo observed in a few } \\
\text { samples (0-3\%) } \\
\text { - Many replaced by cpy (5-15\%) } \\
\text { or py (5-15\%) }\end{array}$} \\
\hline & No original halo & & & \\
\hline \multirow[t]{2}{*}{3} & $\begin{array}{l}\text { bt-qżanh-(chl-cpy- } \\
\text { py-mo) }\end{array}$ & \multirow{2}{*}{$\begin{array}{l}\text { - The most abundant premineralization stage vein, found } \\
\text { throughout the TMC at all mine levels } \\
\text { - Typical thicknesses of } 5-15 \mathrm{~mm} \\
\text { - Rare, thin biotite veins }(<2 \mathrm{~mm} \text { ) found in the A-Porphyry with } \\
\text { extremely rare examples in the diorites }\end{array}$} & \multirow{2}{*}{3347} & \multirow{2}{*}{$\begin{array}{l}\text { - By far the most sulfide-rich } \\
\text { premineralization stage vein } \\
\text { - Up to } 10 \% \text { mo in some samples } \\
\text { - Most contain } 5-30 \% \mathrm{cpy}\end{array}$} \\
\hline & qz-plag halo & & & \\
\hline \multirow[t]{2}{*}{$4 a$} & $\begin{array}{l}\text { qz-Kfsp } \pm \text { anh-(ap- } \\
\text { bt) }\end{array}$ & \multirow{2}{*}{$\begin{array}{l}\text { - Thin wavy veins (0.5-4 } \mathrm{mm} \text { width) found in the TMC } \\
\text { - Rare occurrences within the A-Porphyry and to a lesser extent } \\
\text { the diorites. None observed within the Teniente Dacite Porphyry } \\
\text { - Observed grading into anh-rich veins }\end{array}$} & \multirow{2}{*}{$\begin{array}{l}324 \\
(0.9 \%)\end{array}$} & \multirow{2}{*}{$\begin{array}{l}\text { - Minor primary mo }<1 \% \text { and cpy } \\
<1 \% \text { observed in thin section } \\
\text { only } \\
\text { - No py or bo observed }\end{array}$} \\
\hline & bt halo & & & \\
\hline \multirow[b]{2}{*}{$4 b$} & Kfsp-ep-anh-chl $\pm q z$ & \multirow{2}{*}{$\begin{array}{l}\text { - Very rare vein type, only observed within the TMC and to a } \\
\text { lesser extent the A-Porphyry. Thicknesses of } 1-5 \mathrm{~mm} \\
\text { - Well preserved at deep mine levels and are most frequently } \\
\text { observed in the Sewell Quartz Diorite (Vry et al., 2010) }\end{array}$} & \multirow{2}{*}{$\begin{array}{c}54 \\
(0.2 \%)\end{array}$} & \multirow{2}{*}{$\begin{array}{l}\text { - None observed during this } \\
\text { study }\end{array}$} \\
\hline & local ep halo & & & \\
\hline \multirow[b]{2}{*}{5} & 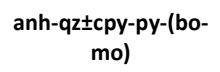 & \multirow{2}{*}{$\begin{array}{l}\text { - Occur throughout the TMC, surrounding the diorites and being } \\
\text { cut by the Teniente Dacite Porphyry. Thicknesses of 1-15 mm } \\
\text { - Most abundant surrounding and in the A-Porphyry (DDH 2305) } \\
\text { - Appear to be spatial association with anhydrite breccias } \\
\text { surrounding the A-Porphyry and diorites }\end{array}$} & \multirow{2}{*}{$\begin{array}{l}1922 \\
(5.8 \%)\end{array}$} & \multirow{2}{*}{$\begin{array}{l}\text { - Extremely variable. } \\
\text { - Typically 0-20\% mo and 0-5\% } \\
\text { bo, usually at contacts } \\
\text { - Can contain up to } 30 \% \mathrm{cpy} \pm \text { py } \\
\text { in some isolated patches }\end{array}$} \\
\hline & $\begin{array}{l}\text { bt in TMC/ } \\
\text { Kfsp or no halo in } \\
\text { felsics }\end{array}$ & & & \\
\hline \multirow{2}{*}{$6 a$} & qz-anh-Kfsp $\pm m o-b o$ & \multirow{2}{*}{$\begin{array}{l}\text { - The most abundant vein type. Present in the TMC and every } \\
\text { intrusion. Typical thickness = 1-30 } \mathrm{mm} \\
\text { - Highest frequency observed within and immediately } \\
\text { surrounding the diorites in dense stockworks } \\
\text { - Slight decrease in abundance of mo-bearing examples with } \\
\text { distance from the felsic-intermediate intrusions } \\
\text { - Abundant at the deepest mine levels studied ( } 1300 \mathrm{~m} \text { asl) } \\
\text { proximal to the diorites }\end{array}$} & \multirow{2}{*}{6585} & \multirow{2}{*}{$\begin{array}{l}\text { - Most Mo rich vein type with 0- } \\
30 \% \text { in most samples } \\
\text { - Mo-rich examples observed at } \\
\text { the deepest mine levels } \\
\text { - Some contain minor bo, which } \\
\text { appears to be co-precipitated } \\
\text { with mo } \\
\text { - Always }<5 \% \text { cpy and }<5 \% \text { py }\end{array}$} \\
\hline & $\begin{array}{l}\text { no halo in the } \\
\text { TMC/ } \\
\text { Kfsp halo in felsics }\end{array}$ & & & \\
\hline \multirow[t]{2}{*}{$6 b$} & $\begin{array}{l}\text { qz-cpy-anh- } \\
\text { Kfsp } \pm m o-b o-p y\end{array}$ & \multirow{2}{*}{$\begin{array}{l}\text { - Abundant throughout the TMC and crosscutting every intrusion. } \\
\text { Typical thicknesses of } 2-25 \mathrm{~mm} \\
\text { - Equally abundant in all the transects studied, but showed a } \\
\text { slightly decreased abundance in the deepest mine levels studied, } \\
\text { particularly in DDH } 1805 \\
\text { - Typically found outboard of type 6a veins in surrounding the } \\
\text { finger porphyries, but also overprinting type 6a veins }\end{array}$} & \multirow{2}{*}{$\begin{array}{c}5961 \\
(19.4 \%)\end{array}$} & \multirow{2}{*}{$\begin{array}{l}\text { - Observed with highly } \\
\text { contrasting sulfides } \\
\text { - Typically contain } 5-40 \% \text { cpy } \\
\text { and/or } \sim 10 \% \text { py. } \\
\text { - } \sim 25 \% \text { contain mo }(5-20 \%) \text { at } \\
\text { vein edges or overprinted by } \\
\text { cpy. Typically }<5 \% \text { bo }\end{array}$} \\
\hline & $\begin{array}{l}\text { no halo in } \\
\text { TMC/Kfsp halo in } \\
\text { felsics }\end{array}$ & & & \\
\hline \multirow[t]{2}{*}{$7 a$} & $\operatorname{mo} \pm(q z-a n h)$ & $\begin{array}{l}\text { - Most observed within the felsic-intermediate intrusions or at } \\
\text { distances }<20 \mathrm{~m} \text { from their contacts }\end{array}$ & & $\begin{array}{l}->70 \% \text { molybdenite } \\
\text { - often surrounded by cpy }\end{array}$ \\
\hline & no halo & $\begin{array}{l}\text { - Typically thin }(0.5-3 \mathrm{~mm}) \text { and often discontinuous } \\
\text { - Some appear transition from type 6a or type } 10 \text { veins }\end{array}$ & $(3.6 \%)$ & $\begin{array}{l}\text { disseminations within } 1 \mathrm{~cm} \text { of } \\
\text { vein edges }\end{array}$ \\
\hline $7 b$ & cpy $\pm q z-a n h$ & $\begin{array}{l}\text { - Observed in every lithology except late breccias. Abundant in } \\
\text { the TMC at shallow mine levels } \\
\text { - } 0.2-20 \mathrm{~mm} \text { thick with abundant, large examples found at 50-100 }\end{array}$ & 3670 & $\begin{array}{l}\text { - }>70 \text { cpy. No coprecipitated mo } \\
\text { present although }\end{array}$ \\
\hline & no halo & $\begin{array}{l}\mathrm{m} \text { from the contacts of the intrusions } \\
\text { - Vast number of veins coat edges of broken drillcore }\end{array}$ & $(10.7 \%)$ & $\begin{array}{l}\text { overprinted by cpy in reflected } \\
\text { light }\end{array}$ \\
\hline & cpy-py-qz-anh-mo & $\begin{array}{l}\text { - Particularly abundant at shallow mine levels surrounding the } \\
\text { Teniente Dacite Porphyry or in distal settings of the TMC from }\end{array}$ & 6479 & - Almost all contain cpy (5-60\%) \\
\hline 8 & ser-chl-qz halo & $\begin{array}{l}\text { the diorites ( }>50 \mathrm{~m} \text { from margins). Typical thicknesses }=2-15 \\
\mathrm{~mm} \\
\text { - Rare occurrences ( }<10 \% \text { of total recorded) within the felsic- } \\
\text { intermediate intrusions or at depths }<1900 \mathrm{~m} \text { asl }\end{array}$ & $(19.2 \%)$ & $\begin{array}{l}\text { and/or py (5-30\%) } \\
\text { - Rare examples contain mo and } \\
\text { bo ( } 5-10 \%)\end{array}$ \\
\hline 9 & $\begin{array}{l}\text { tour-cb-anh } \pm \text { cpy- } \\
\text { py-bo-mo }\end{array}$ & $\begin{array}{l}\text { - Abundant within } 300 \mathrm{~m} \text { of the Braden pipe margins, cutting all } \\
\text { lithologies with typical thicknesses of } 1-20 \mathrm{~mm} \\
\text { - Most commonly observed in the TMC in DDH 1888, 2716, } 1754\end{array}$ & 2837 & $\begin{array}{l}\text { - Typically contain } 0-25 \% \text { mo } \\
\text { with minor bo or } 0-10 \% \text { cpy + } \\
\text { minor py }(<5 \%)\end{array}$ \\
\hline & ser-chl-qz halo & $\begin{array}{l}\text { and } 2672 \text {, where they appear to be closely spatially associated } \\
\text { with the presence of tour breccias }\end{array}$ & (5.1\%) & $\begin{array}{l}\text { - Barren examples recorded, at } \\
\text { deeper mine levels }\end{array}$ \\
\hline 10 & $\begin{array}{l}\text { cb-anh-gyp } \pm \text { ten- } \\
\text { cpy-py-bo-mo }\end{array}$ & $\begin{array}{l}\text { - Found throughout the deposit with increased abundance at } \\
\text { shallower mine levels. Crosscut all intrusions and are reported in } \\
\text { the Braden pipe. Thicknesses are } 5-50 \mathrm{~mm}\end{array}$ & 1353 & $\begin{array}{l}\text { - Contain } 10-50 \% \text { mo often with } \\
10-20 \% \text { bo, typically at vein } \\
\text { margins }\end{array}$ \\
\hline & ser-chl-qz halo & $\begin{array}{l}\text { - Show a good spatial relationship with NW-trending faults and } \\
\text { concentric faults that surround the Braden pipe }\end{array}$ & (3.6\%) & $\begin{array}{l}\text { - Some examples (<10\%) contain } \\
\text { cpy and/or py ( } 5 \%)\end{array}$ \\
\hline
\end{tabular}

Notes: $\mathbf{N}=$ number of veins of each type recorded with percentage proportions displayed in brackets below (total number of veins of each vein type/total veins recorded). 


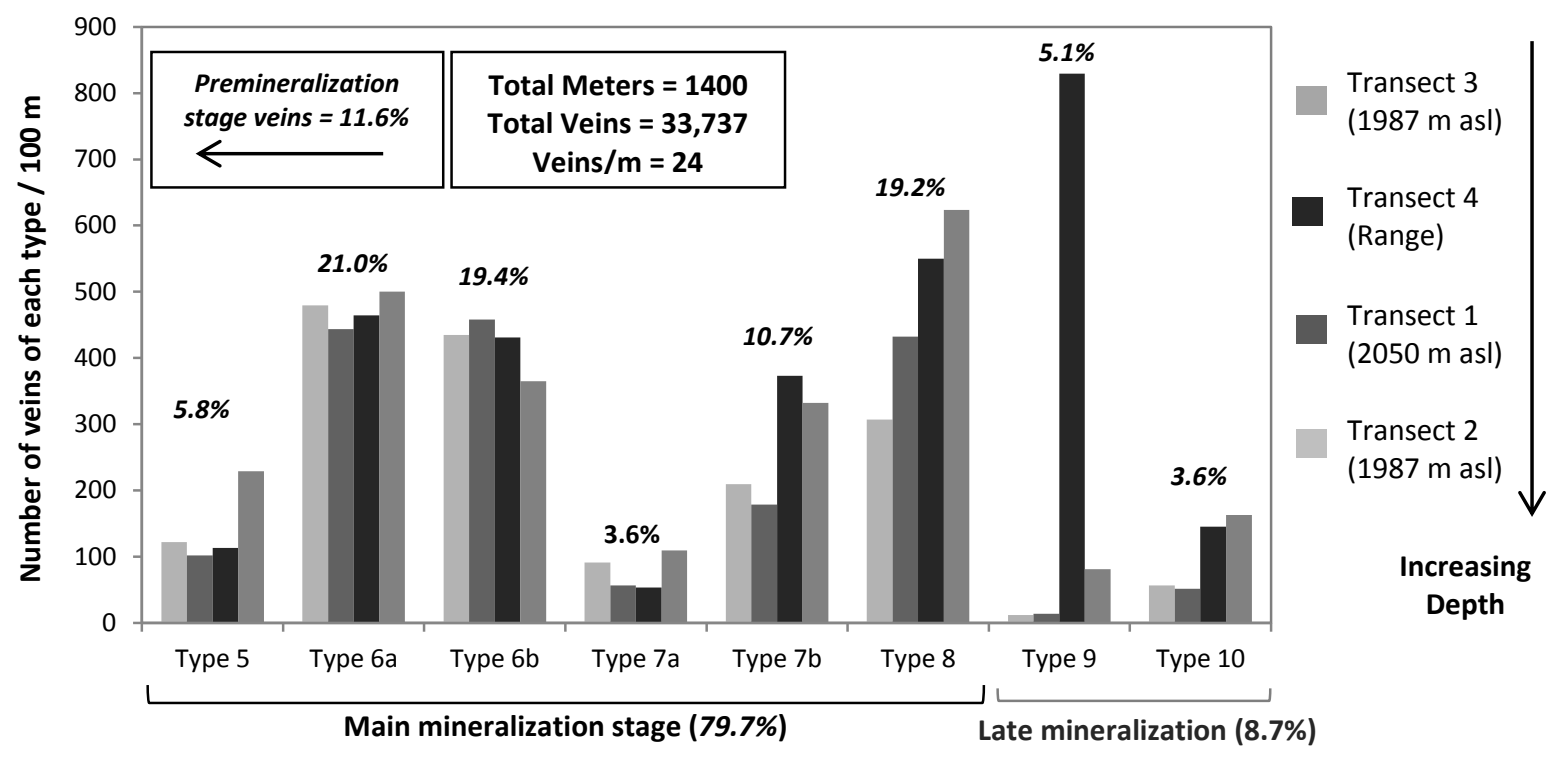

Fig. 10: Number of veins of each vein type per $100 \mathrm{~m}$ in transects 1-4. Main mineralization stage veins account for $\sim 80 \%$ of all veins recorded due to the high proportions of type $6 \mathrm{a}, \mathbf{6 b}$ and 8 veins observed in all transects (Table 2). Premineralization stage veins are not plotted due to low abundances and lack of sulfides. Overall relative vein type abundances (number of veins of type/total veins) are shown in italics.

\section{Premineralization stage veins}

Premineralization stage veins are abundant within the TMC, the Sewell Quartz Diorite and, to a lesser extent, the A-Porphyry, but are extremely rare in the diorites and Teniente Dacite Porphyry. Of these, type 3 and 4 a veins were the only abundant veins observed in transects 1-4 (Table 4). Type 3 veins have modal widths of approximately $8 \mathrm{~mm}$ and commonly contain abundant chalcopyrite and/or molybdenite (Table 4). Despite this, type 3 vein abundance shows no clear relationship with Mo and $\mathrm{Cu}$ grades in transects 1-4 (Fig. 11A-D). Type 3 vein abundance data fall in clusters relating to host rocks, with the TMC being typified by higher pre-mineralization stage vein abundances and a slight bias towards higher $\mathrm{Cu}$ grades relative to Mo (Fig. 11A-B). There is a weak negative correlation between type 3 vein abundance and Cu grades in the TMC (Fig. 11D) suggesting that these veins are not economically important. Furthermore, thin section analysis reveals that molybdenite and chalcopyrite typically replace biotite in type 3 vein centers where they are sometimes accompanied by minor sericitic alteration. This suggests that sulfide-rich type 3 veins are the product of overprinting by later vein stages (e.g. Mo-rich type 7a veins: Fig. 5C).

Type $4 a$ veins commonly have widths of $<1 \mathrm{~mm}$, accounting for their low abundance in the vein distribution analysis (Table 4). Reflected light analysis reveals that they typically contain $<1 \%$ molybdenite and Cu-sulfides that do not appear to be the product of overprinting. These low 
primary sulfide abundances confirm their previous categorization as premineralization stage veins (Vry et al., 2010).
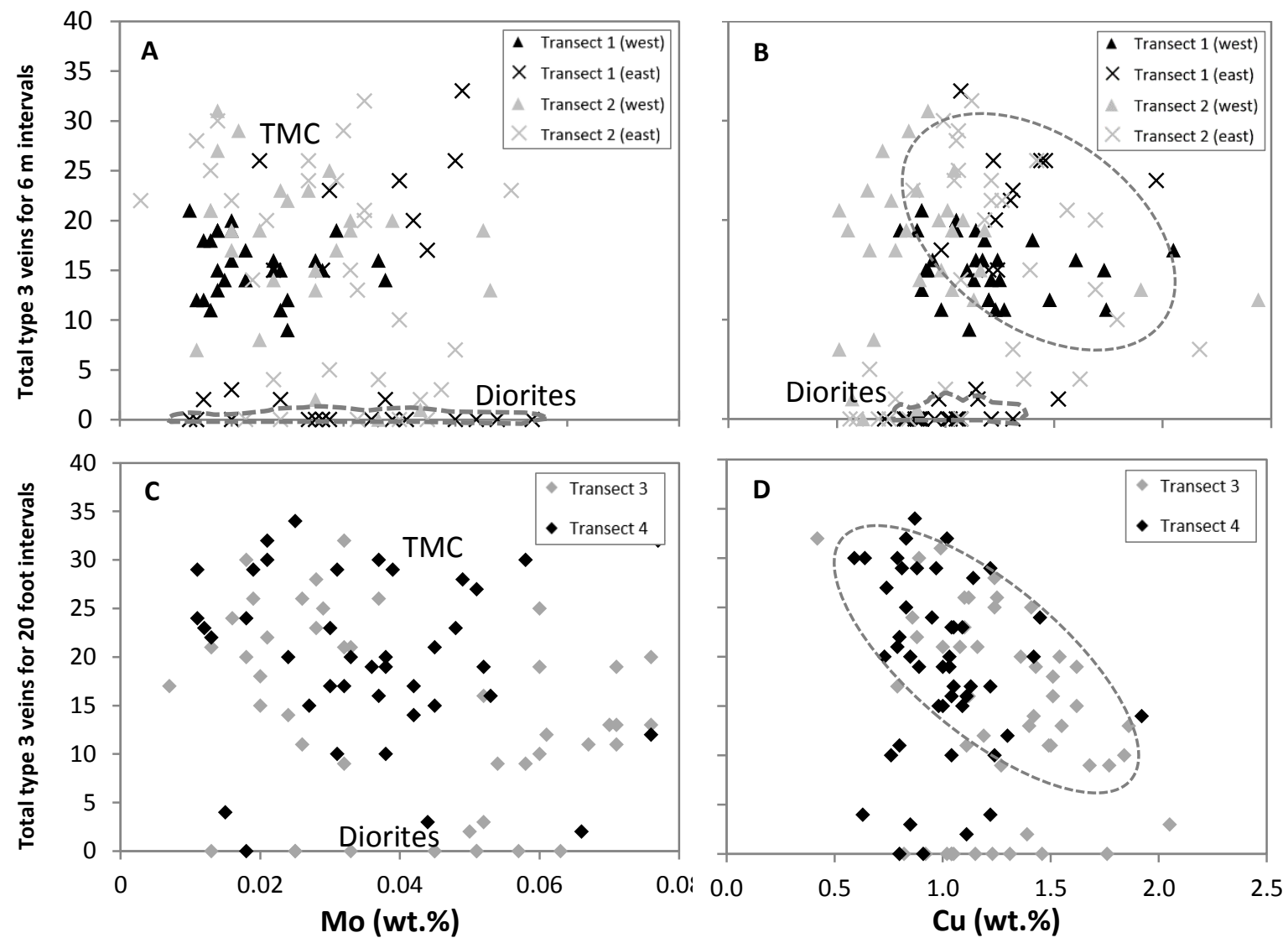

Fig. 11: (A-B) Total number of type 3 veins versus average Mo and $\mathrm{Cu}$ grades for six meter intervals in the two deepest transects (transect 1 = black, transect $\mathbf{2}=$ grey). (C-D) Abundance of type $\mathbf{3}$ veins versus average $\mathrm{Mo}$ and $\mathrm{Cu}$ grades for $\mathbf{2 0}$ foot intervals in the two shallowest transects (Transects = grey diamonds, Transect 4 = black diamonds). Grade data courtesy of CODELCO Division El Teniente.

Main mineralization stage veins

Main mineralization stage veins occur throughout the TMC as well as within every intrusion at El Teniente. In accordance with previous studies (Camus, 1975; Cannell et al., 2005; Vry et al., 2010), these veins were found to be particularly abundant immediately surrounding the felsicintermediate intrusions. Type 5 veins are abundant in the A-Porphyry, but less so in the diorites and Teniente Dacite Porphyry, suggesting that they predominantly formed prior to the final emplacement of these units in their respective parts of the deposit. Reflected light analysis of Morich type 5 veins revealed that molybdenite is locally present as large, bladed crystals concentrated at vein margins, associated with quartz (Fig. 9D). In contrast, Cu-rich examples typically exhibit large chalcopyrite crystals intergrown with anhydrite in sites that appear to represent the final stages of 
vein infill. Mo and Cu grades display no clear relationship with the abundance of type 5 veins in each drillcore interval (Fig. 12). This, combined with the fact that type 5 veins account for $<6 \%$ of veins recorded (Fig. 10), indicates that they are of limited importance in controlling grade distributions in transects 1-4.
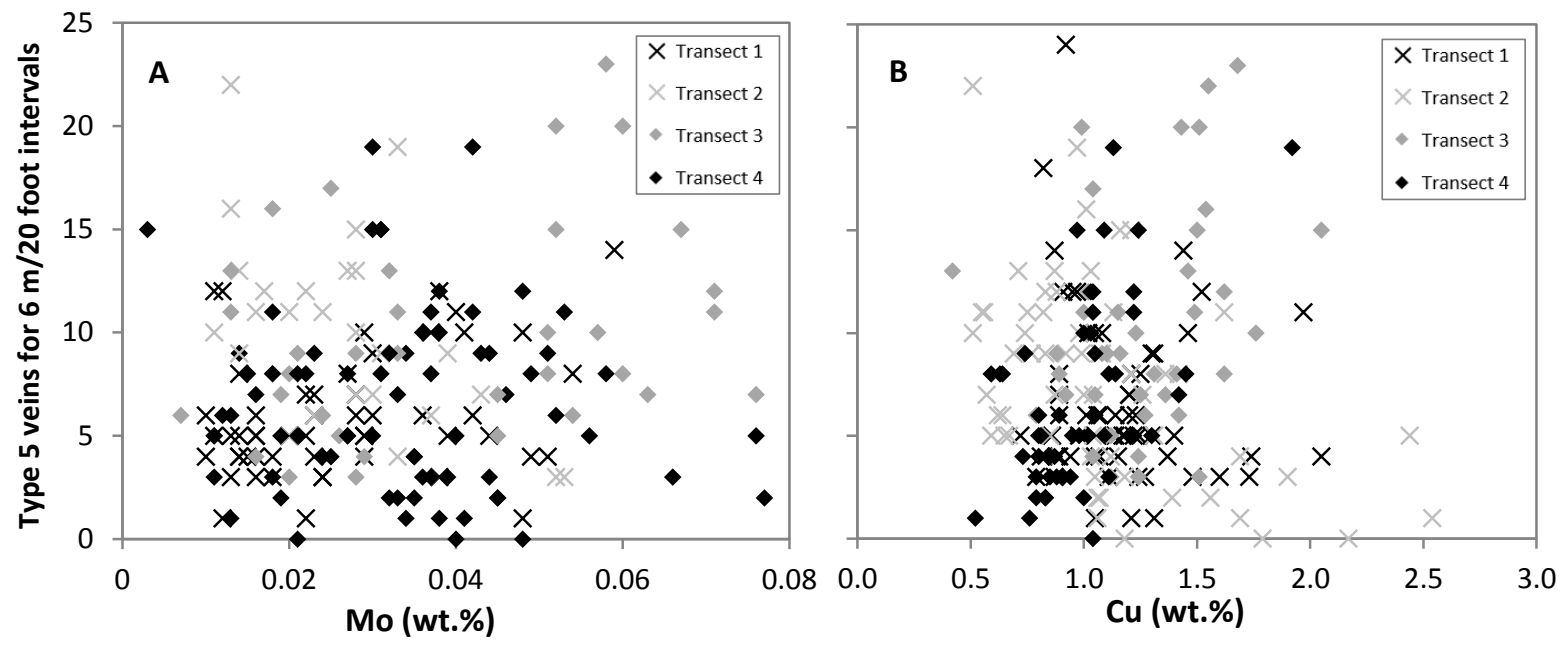

Fig. 12: Total number of type 5 veins versus average $M o(A)$ and $C u(B)$ grades for six meter intervals in the two deepest transects (Transect 1 = black crosses and Transect $\mathbf{2}=$ grey crosses) and in the two shallowest transects (Transect $\mathbf{3}$ = grey diamonds and Transect $\mathbf{4}$ = black diamonds). Grade data courtesy of CODELCO Division El Teniente.

Quartz-dominated type 6 veins account for $\sim 40 \%$ of all veins recorded (Fig. 10) and are observed throughout the TMC and within all intrusions (Table 4). These veins display similar abundances at all mine levels (e.g. Fig. 10) but the proportion of Mo-rich type 6a veins generally increases with depth. Mo grades exhibit the strongest positive relationship with type 6a veins than with the abundances of any other vein type in transects 1 and 2 (Fig. 13A-B). This relationship is particularly strong at deep mine levels in the drillcores that intersected the Northern and North Central Diorites $($ DDH $2371=$ Transect 1-east and DDH $2215=$ Transect 2-east). These drillcores contain fewer type 6 a veins than the drillcores that traversed the TMC to the west, suggesting that Mo-poor type 6a veins also formed in more distal settings of the TMC relative to the diorites. However, Mo grades in the TMC still show a stronger relationship with type 6a vein abundance than any other main mineralization vein type. This relationship is also apparent in transects 3 and 4 if the cluster of data with unusually high Mo grades is excluded (Fig. 13B). These high grades are likely to be associated with paragenetically later Mo-rich vein and breccia types that occur at shallow mine levels (Table 3A). 

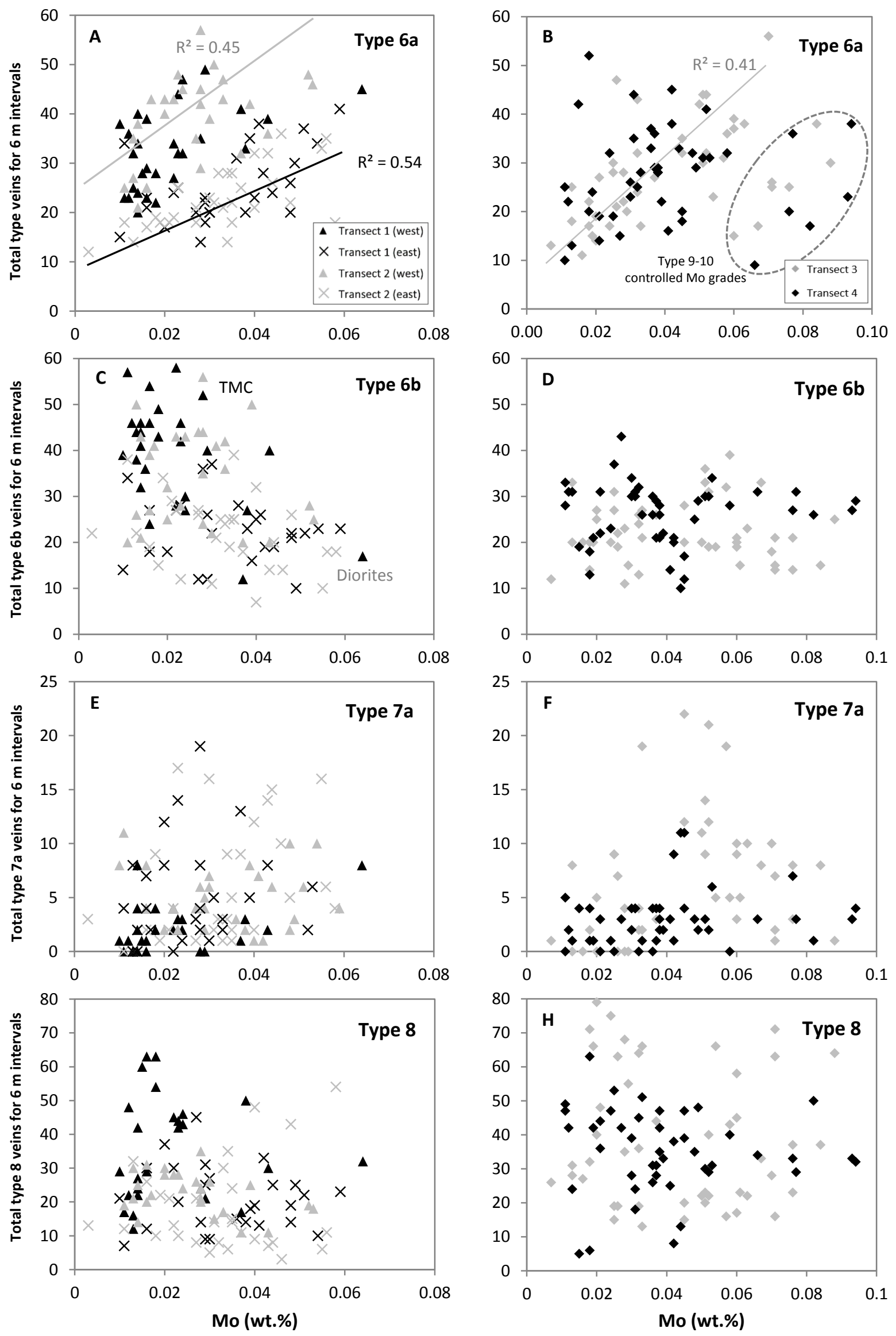

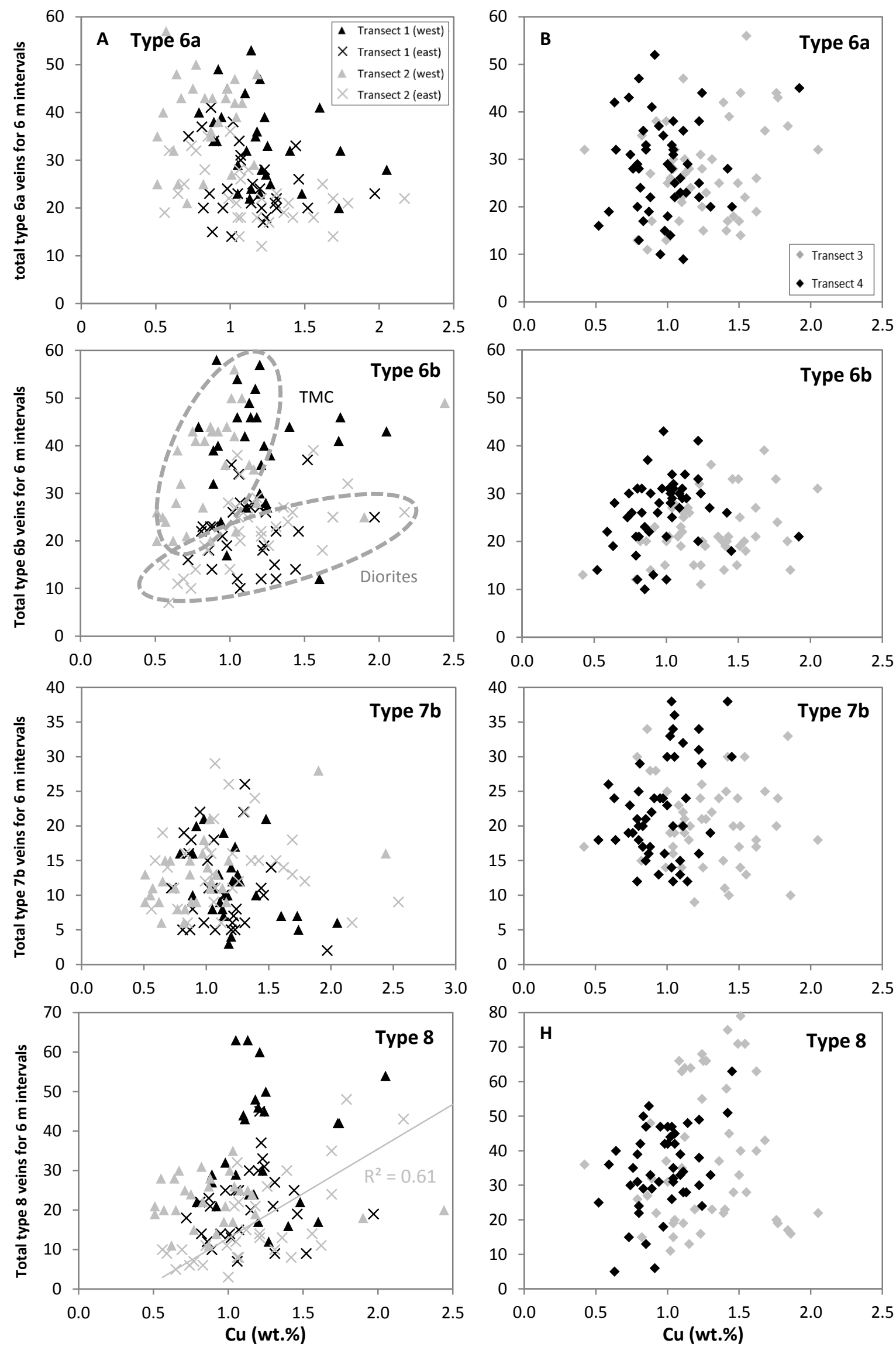
Fig. 13 A-H: Total number of main mineralization stage (type 6a-8) veins versus average Mo grades (wt.\%) for six meter intervals in transects 1-2 and 20 foot intervals for transects 3-4. Transect 1 (2250 $\mathrm{m}$ asl) and transect 2 (1987 $\mathrm{m}$ asl) data are plotted on the left hand column. Transect 1-west = black triangles, transect 1-east $=$ black crosses, transect 2 -west $=$ grey triangles, transect 2-east $=$ grey crosses. Transect 3 (grey diamonds) and transect 4 (black diamonds) are plotted on the right. Due to their lack of contained molybdenite type $7 \mathrm{~b}$ veins were not plotted. Type $6 \mathrm{a}$ veins show the strongest positive correlation with Mo grades of any vein type in all transects. Note the similar trends for drillcores that cut through the Northern Diorite and North Central Diorite (transect 1-east and transect 2-east), and the similar trends for drillcores that predominantly cut the TMC host rock to the west of the diorites (transect 1-west and transect 2-west). Brecciated drillcore intervals and drillcore intervals with $>8$ late mineralization stage veins are not plotted. Grade data courtesy of CODELCO Division El Teniente.

Fig. 14 A-H: Total number of main mineralization stage (type 6a-8) veins versus average Cu grades (wt.\%) for six meter intervals in transects 1-2 and 20 foot intervals for transects 3-4. Transect 1 (2250 m asl) and transect 2 (1987 $\mathrm{m}$ asl) data are plotted on the left hand column. Transect 1-west = black triangles, transect 1-east $=$ black crosses, transect 2 -west $=$ grey triangles, transect 2 -east $=$ grey crosses. Transect 3 (grey diamonds) and transect 4 (black diamonds) are plotted on the right. Due to their lack of contained chalcopyrite and/or bornite type 7a veins were not plotted. Brecciated drillcore intervals and drillcore intervals with $>8$ late mineralization stage veins are not plotted. Grade data courtesy of CODELCO Division El Teniente.

Copper grades display a weak negative correlation with the abundance of type 6a veins (Fig. 14A-B) but show a clear positive correlation with the abundance of type 6b veins (Fig. 14C-D). These chalcopyrite-rich veins are particularly abundant in the TMC in the deeper transects (DDH $2363=$ T1west and DDH $2230=$ T2-west) where their frequency often exceeds 8 veins/meter (Fig. 14C). Three, Mo-rich, type $6 \mathrm{~b}$ vein subtypes are recognized in this study that showed clear evidence of early molybdenite mineralization at the vein edges (e.g. Fig. 9F-G), or at the vein center with a chalcopyrite overprint (e.g. Fig. 9E). Although these Mo-rich examples are relatively abundant within and surrounding all intrusions, type $6 \mathrm{~b}$ vein abundance displays an inverse correlation with Mo grades in the two deepest transects (Fig. 13B). This trend is similar to the inverse relationship displayed between Cu grades and type 6a vein abundances (Fig. 14A).

Type 7a veins appear to be transitional veins from the quartz-rich type $6 a$ and $6 \mathrm{~b}$ veins (e.g. Fig. 9I). However, the classification scheme of Vry et al. (2010) does not present a threshold sulfide abundance for this transition. We therefore define type 7 vein as containing $>70 \%$ sulfides that have no significant associated sericitic alteration. Molybdenite-dominated type 7 a veins account for $<5 \%$ of all veins recorded (Fig. 10) and are typically thin $(<2 \mathrm{~mm})$ and commonly discontinuous. These predominantly occur within or proximal to $(<20 \mathrm{~m})$ the felsic-intermediate intrusions, in part accounting for the high vein densities and Mo grades surrounding them. However, these veins display no clear relationship with Mo grade (Fig. 13E-F), suggesting that they are of insufficient size and frequency to significantly control Mo grade distribution. Reflected light analysis of several type 
7a veins revealed that they do not contain co-precipitated $\mathrm{Cu}$, but are commonly surrounded by significant amounts of disseminated chalcopyrite in the wallrock (e.g. Fig. 9l).

Chalcopyrite-dominated type $7 \mathrm{~b}$ veins with widths $>1 \mathrm{~mm}$ are approximately four times more abundant than type 7a molybdenite veins (Fig. 10) and occur throughout the TMC where they have average thicknesses of 5-10 mm (Table 4). Despite this, plots of $\mathrm{Cu}$ grade against type $7 \mathrm{~b}$ abundances also display no clear correlations (Fig. 14E-F). This is largely attributed to the fact that, unlike other vein types, type $7 \mathrm{~b}$ veins are commonly $<1 \mathrm{~mm}$ thick and therefore a considerable proportion (20-40\%) were not recorded. This undersampling is particularly likely in the deeper transects and within the felsic-intermediate intrusions where the number of recorded type $7 \mathrm{~b}$ veins was typically less than 5 veins/meter even though chalcopyrite commonly coats fractured drillcore surfaces. This is therefore the most problematic limitation of the vein distribution analysis technique used.

Type 8 veins account for approximately $20 \%$ of the total number of veins recorded. These veins are particularly abundant at shallow mine levels (e.g. Fig. 10) as well as within drillcores containing abundant TMC intervals (Fig. 13G: DDH 2363 = Transect 1-west and DDH $2230=$ Transect 2 -west). Similar to type $6 \mathrm{~b}$ veins, type 8 vein abundance generally increases with distance from the felsic-intermediate intrusions (e.g. Fig. 15). These veins are typically composed of more anhydrite and less quartz than the type 6 veins and commonly host significant chalcopyrite, bornite and pyrite (e.g. Fig. 9K). Molybdenite-bearing type 8 veins are relatively rare (e.g. Fig. 9J), are typically more quartz-rich, and generally have narrow alteration halos in which unaltered feldspar can be observed. In rare cases where Mo-rich veins are surrounded by more intense sericitic alteration, reflected light microscopy revealed that molybdenite is typically overprinted by chalcopyrite and/or bornite (e.g. Fig. 9K). This suggests that Mo was deposited prior to a copper sulfide + anhydrite-sericite overprint. Consistent with petrographic observations, Mo grades show no relationship with type 8 vein abundances (Fig. 13G-H). In contrast, type 8 veins display the clearest positive relationship with $\mathrm{Cu}$ grade of any vein type in all transects (Fig. 14G-H). Peak Cu grades commonly coincide with peak type 8 vein abundance between 60 and 120 meters from the diorite intrusion margins (e.g. Fig. 15). 
Transect 2: DDH 2215

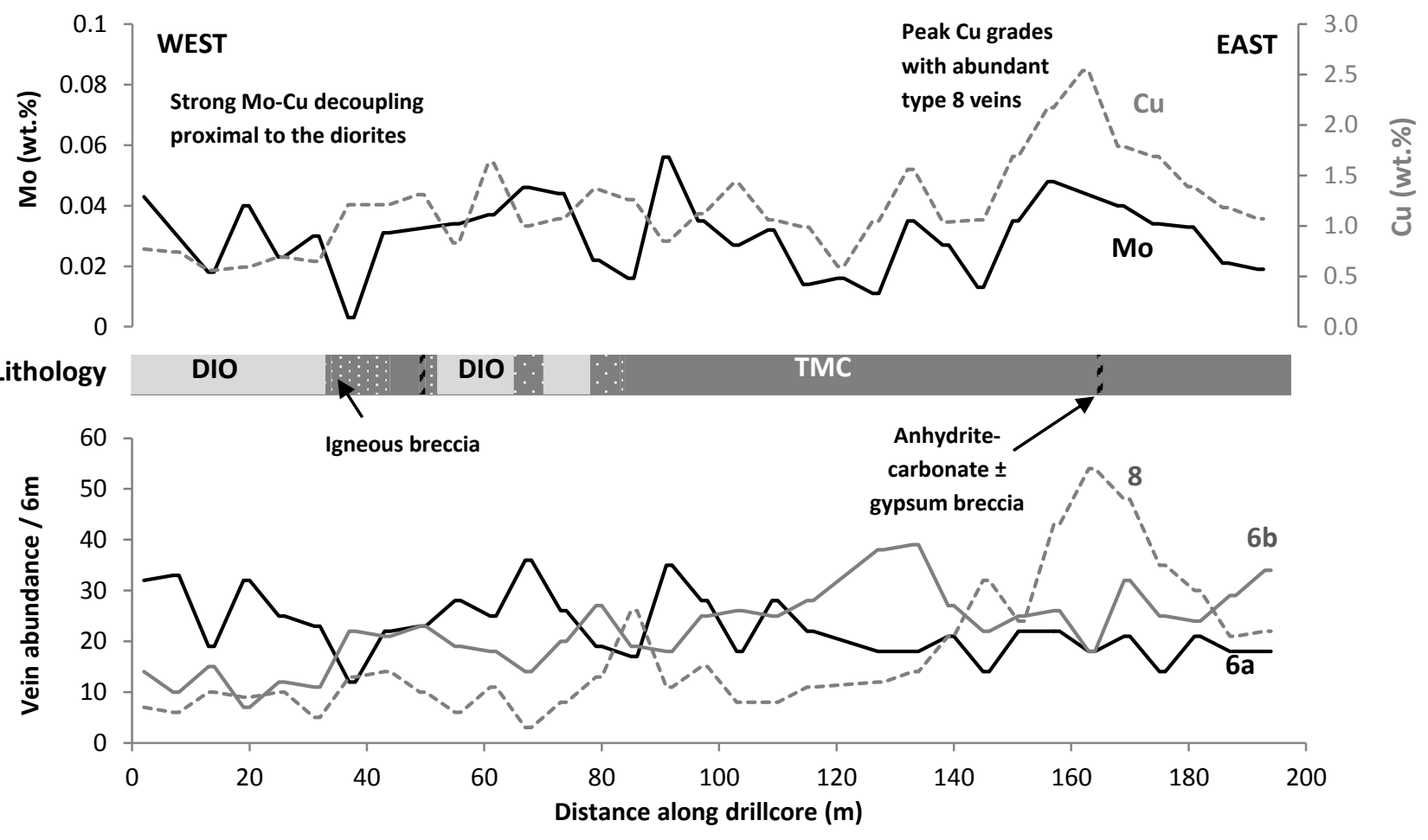

Fig. 15: Mo and $\mathrm{Cu}$ grades (wt.\%) versus lithology and the abundances of type $6 \mathrm{a}, 6 \mathrm{~b}$ and type 8 veins along transect 2 heading to the east of the North Central Diorite (DDH 2215). Results show fluctuating Mo grades that correlate well with intervals containing abundant type 6a veins. There is a slight decrease in the abundance of type $6 a$ veins and a general increase in type $6 \mathrm{~b}$ and 8 vein abundances with distance from the intrusion. High $\mathrm{Cu}$ grades correlate well with peaks in type $6 \mathrm{~b}$ and 8 vein abundances (e.g. $136 \mathrm{~m}$ and 165 $\mathrm{m}$ ). Decoupling of $\mathrm{Mo}$ and $\mathrm{Cu}$ is most prominent within $40 \mathrm{~m}$ of the intrusion. Abbreviations: IG = igneous breccia, DIO = Diorite (North Central Diorite), TMC = Teniente Mafic Complex.

\section{Late mineralization stage veins}

Type 9 tourmaline veins were observed throughout the deposit, cutting all intrusions. These accounted for $<1 \%$ of veins recorded in transects 1-3 (Fig. 10), but for a quarter of veins in transect 4 (Fig. 10). Here they form an apparent vein halo surrounding the Braden Breccia pipe, in which veins commonly contain abundant molybdenite that is intergrown with, or overprints, large, acicular tourmaline crystals (e.g. Fig. 9L). Consistent with this, type 9 vein abundance appears to exert a strong control on Mo grades in transect 4, but displays no relationship in transect 3 (Fig. 16A). In contrast, $\mathrm{Cu}$ grades tend to be low and consistent (0.6-1.2 wt.\%) in transect 4 (Fig. 16B) but are generally slightly higher in transect 3 (Fig. 16B) where several chalcopyrite-bearing type 9 veins were observed. 

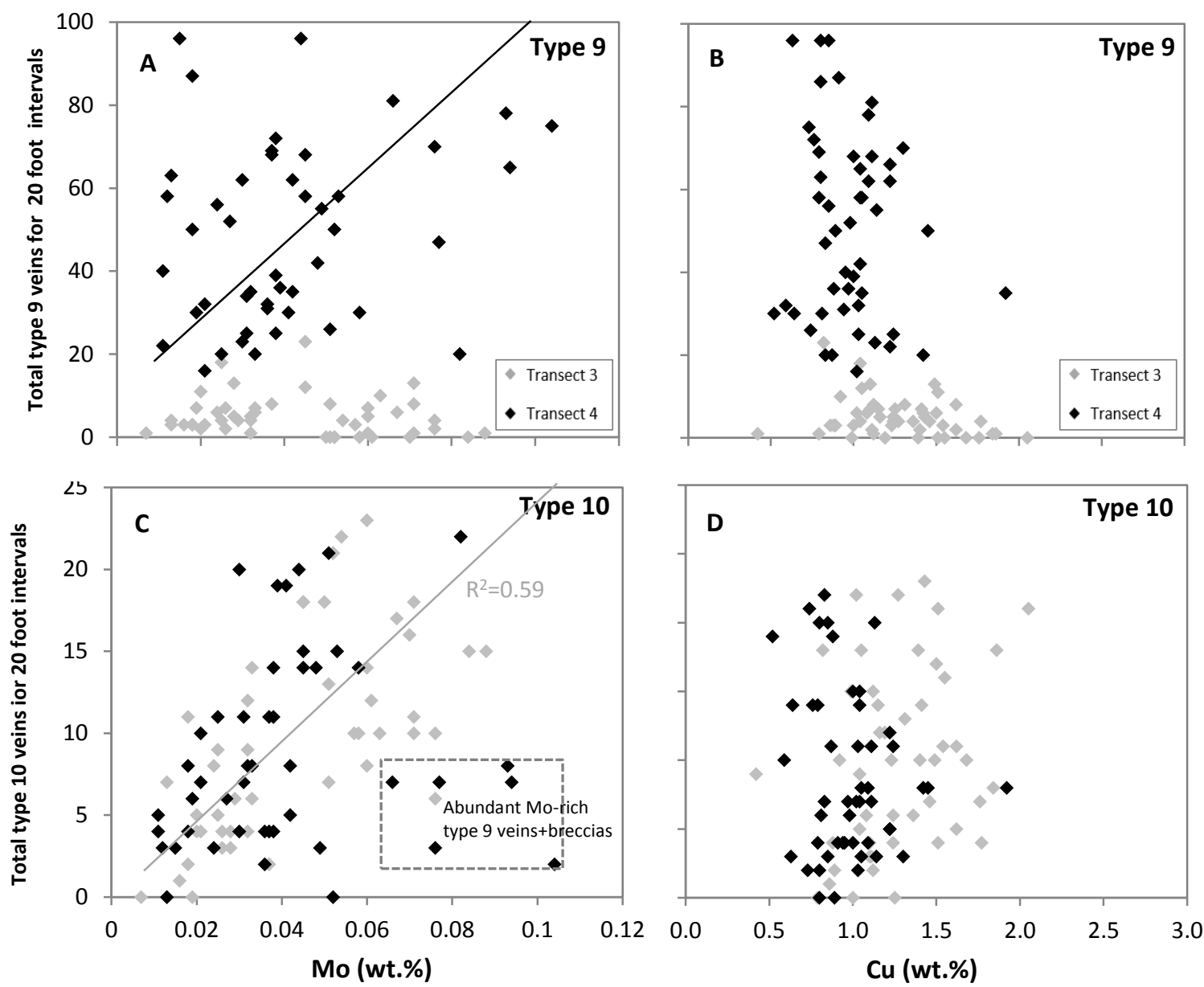

Fig. 16: Total number of type 9 (A-B) and type 10 (C-D) veins versus average Mo and $\mathrm{Cu}$ grades for 20 foot intervals in the two shallowest transects studied (transect 3 = grey diamonds, transect 4 = black diamonds). Due to the extremely low number of type 9 and 10 veins recorded in the two deeper transects (transects 12), these veins were not considered important in controlling grade distributions at deep mine levels. As a result, late mineralization stage vein abundances in transects 1-2 were not plotted. Type 9 vein abundances in transect 4 display a positive relationship with Mo grades (A) whereas type 10 veins show the strongest positive relationships with Mo grade of any vein type in transect 3 (C). Cu grades display no relationship with type 9 or 10 veins in both transects.

Type 10 anhydrite-carbonate \pm gypsum veins were observed cross-cutting type 9 veins (e.g. Fig. 9M) and appear to show a close spatial association with concentric and northwest-trending faults surrounding the Braden Breccia pipe (Table 4). Molybdenite is again abundant in these veins and typically occurs at the vein edges alongside variable amounts of bornite \pm chalcopyrite. Thin section analysis of a number of these veins revealed clear evidence of reopening, with gypsum, anhydrite and carbonate overprinting sulfide mineralization (e.g. Fig 10N). Isolated and tarnished fragments of bornite were also observed in several coarse gypsum veins. Although type 10 veins account for $<4 \%$ of total veins recorded, their abundance displays a strong positive relationship with Mo grade in drillcore intervals in the shallow transects (Fig. 16C). In contrast, Cu grades display a highly variable 
relationship with the abundance of type 10 veins (Fig. 16D) as well as their associated anhydritecarbonate \pm gypsum breccias (e.g. Table 3 ). This probably reflects the highly variable amounts of contained chalcopyrite and bornite in this stage.

\section{Breccia-Vein Relationships}

Plots of vein abundance data against lithology for transects 1-4 reveal clear spatial relationships between the type 5, 9 and 10 veins and anhydrite-, tourmaline- and anhydrite-carbonate \pm gypsumcemented breccias respectively. For example, type 5 veins in transect 2 clearly represent vein halos around anhydrite-cemented breccia bodies (Fig. 17). Strong spatial correlations are also observed between type 9 veins and tourmaline breccias in transect 4 (Fig. 18) and between type 10 veins and anhydrite-carbonate \pm gypsum breccias in transects 2 (Fig. 17) and 3 (Fig. 19). These breccias and their interpreted vein halos often spatially correlate with elevated Mo and $\mathrm{Cu}$ grades. This is particularly noteworthy for Mo, which is generally enriched in sections of drillcore that contain tourmaline- (type 9) and anhydrite-carbonate \pm gypsum-cemented (type 10) breccias (Figs. 16-18).

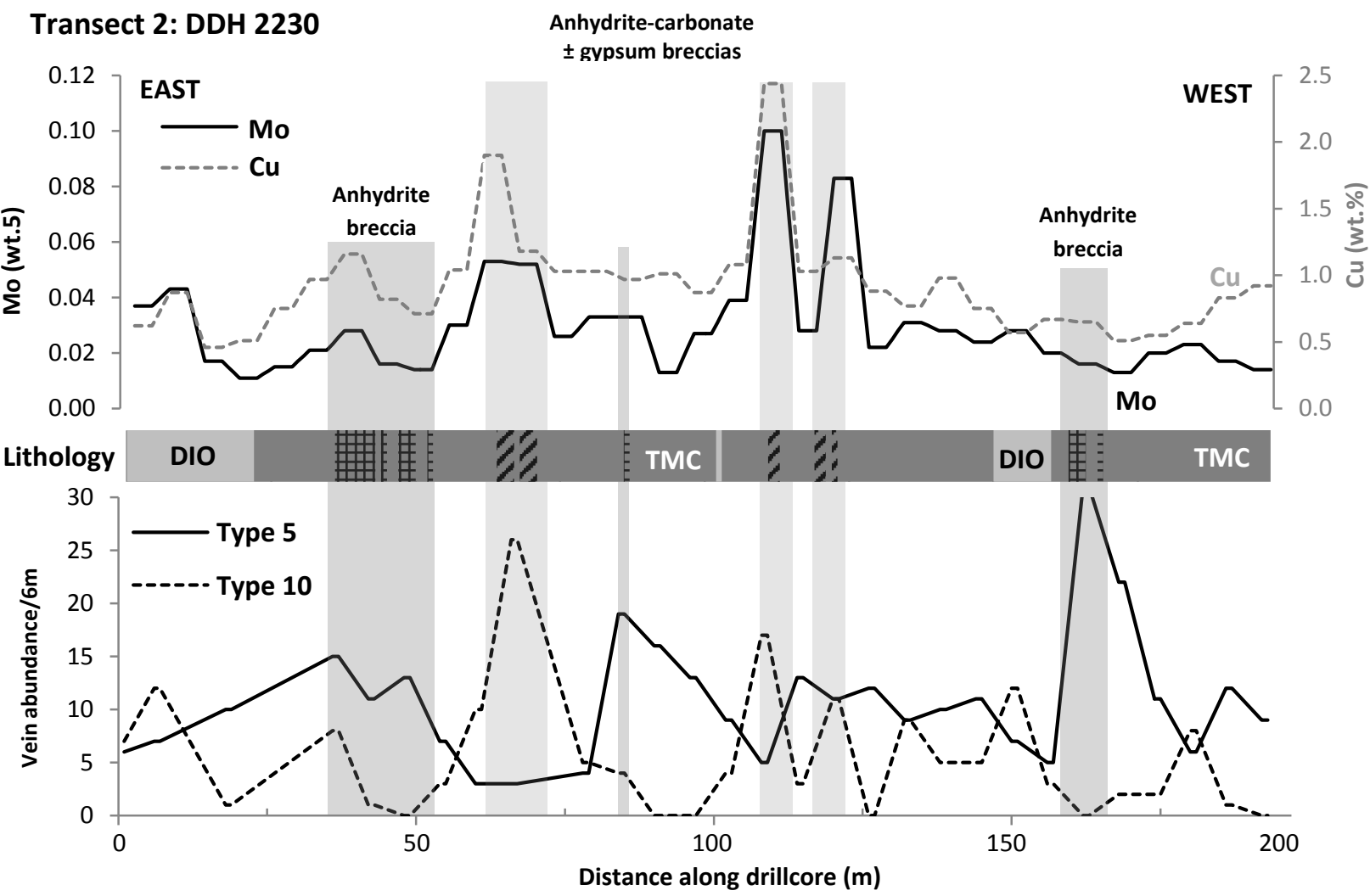

Fig. 17: Mo and $\mathrm{Cu}$ grades (wt.\%) plotted against host lithology and the abundances of type 5 and type 10 veins for six meter intervals along transects 2 west (DDH 2230). Results show a good spatial relationship between type 5 veins and inferred associated anhydrite breccias and type $\mathbf{1 0}$ veins and their inferred associated anhydrite-carbonate \pm gypsum breccias (grey columns). Mo and $\mathrm{Cu}$ grades show a good spatial relationship with the presence of type 10 veins and their associated breccias. 
Transect 4: DDH 1888

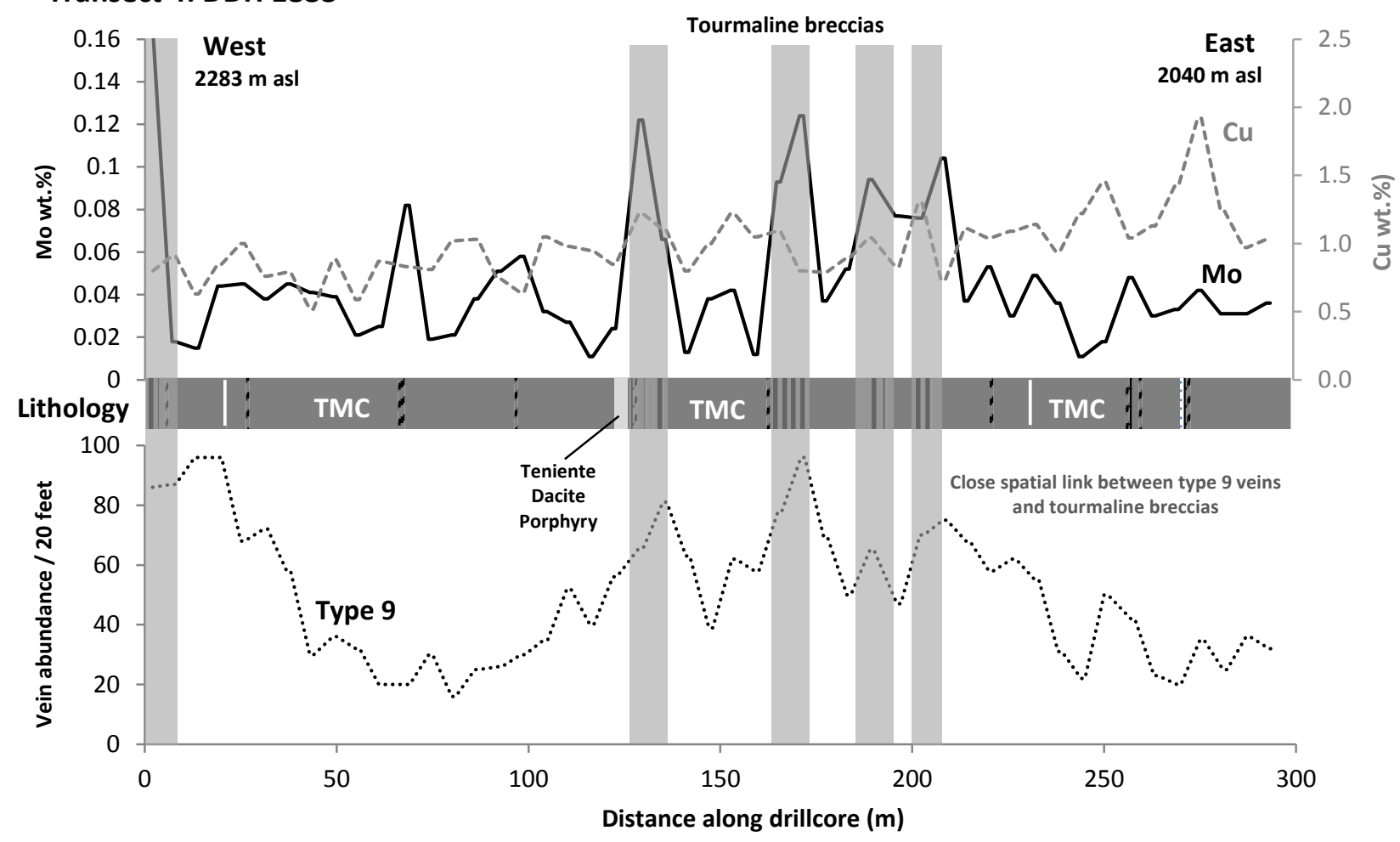

Fig. 18: Mo and $\mathrm{Cu}$ grades (wt.\%) plotted against host lithology and the abundances of type 9 veins for 20 foot intervals along transects 4 (DDH 1888). Results show a good spatial relationship between the presence of tourmaline breccias (grey columns) and the abundance of type 9 tourmaline veins. These correlate well with peak Mo grades whereas $\mathrm{Cu}$ shows no clear relationship with this vein/breccia stage. 
Transect 3: DDH 2083

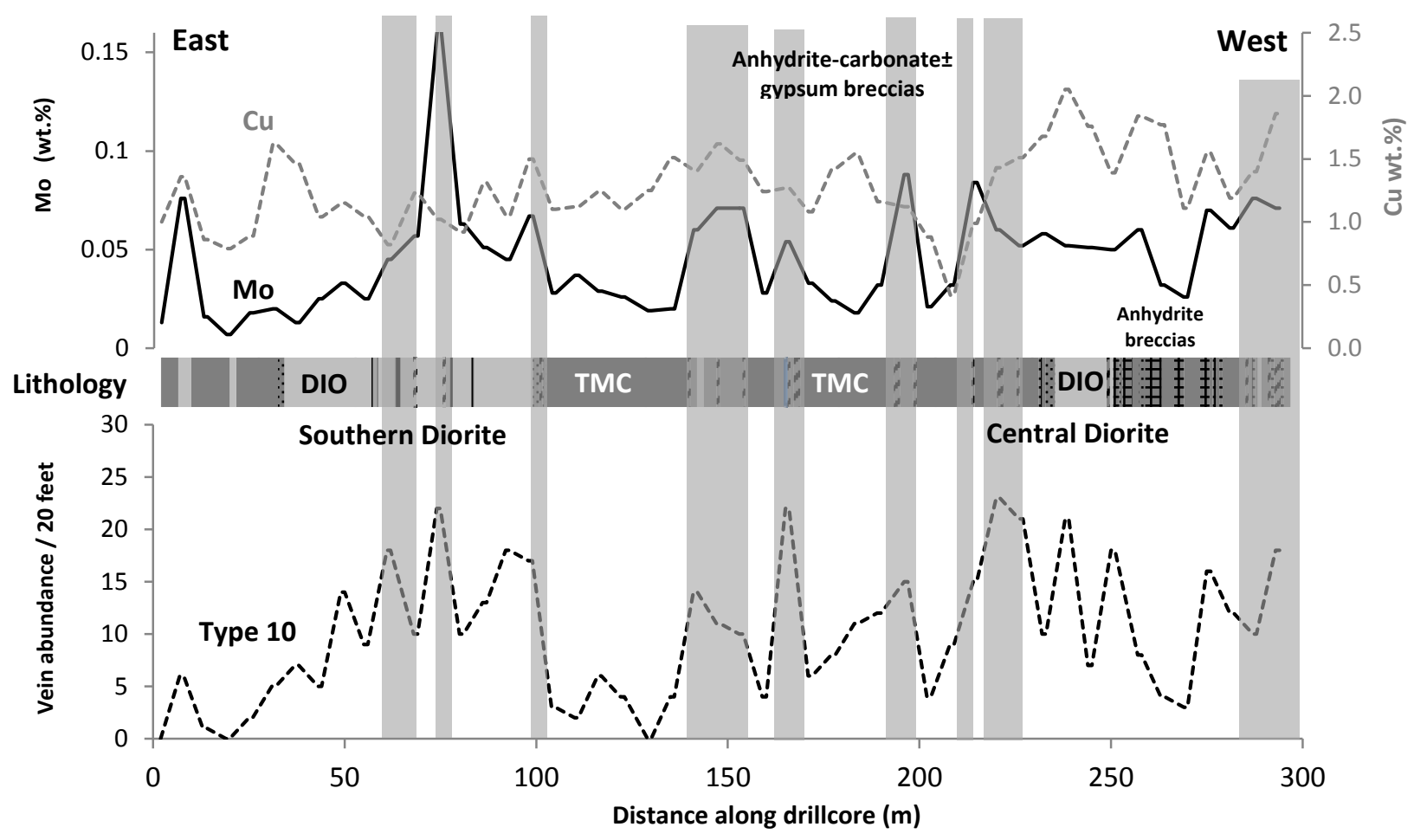

Fig. 19: Mo and $\mathrm{Cu}$ grades (wt.\%) plotted against host lithology and the abundance of type 10 veins for 20 foot intervals along transect 3 (DDH 2083). Peak Mo grades are well correlated with the presence of type 10 anhydrite-carbonate gypsum breccias (grey columns), whereas $\mathrm{Cu}$ grades show a strong spatial correlation with anhydrite breccias proximal to the Southern Diorite. Mo grades show a spatial association with peaks in the abundance of type 10 veins whereas $\mathrm{Cu}$ shows no clear relationship. 


\section{Geochronology}

The timing of mineralization

The 11 molybdenite samples dated in this study by Re-Os document 0.83 million years of mineralization between $5.411 \pm 0.022 \mathrm{Ma}$ and $4.584 \pm 0.022$ (4.580 \pm 0.019 Ma replicate: Table 5). This age range is shorter than the 1.9 m.y. range presented by previous studies (Maksaev et al., 2004; Cannell, 2004), which include older Re-Os ages of $6.31 \pm 0.03 \mathrm{Ma}$ and $5.60 \pm 0.02 \mathrm{Ma}$ (Maksaev et al., 2004), and $5.897 \pm 0.020 \mathrm{Ma}$ (Cannell, 2004) for anhydrite breccias associated with the older Sewell Quartz Diorite and A-Porphyry intrusions.

The oldest molybdenite ages recorded in this study are for main mineralization stage veins within the Southern Diorite and to the north of the Central Diorite (Table 5; Fig. 20). These type 6a, $6 \mathrm{~b}$, and type 8 veins cluster at ages between $5.411 \pm 0.022$ and $5.322 \pm 0.022 \mathrm{Ma}$. Molybdenite hosted by the B-fault yields an age of $4.967 \pm 0.039 \mathrm{Ma}$, which coincides with the oldest main mineralization stage veins spatially associated with the Teniente Dacite Porphyry and Northern Diorite (Fig. 20). Previously dated main mineralization stage veins in this part of the deposit cluster between $4.980 \pm 0.035$ and $4.78 \pm 0.03 \mathrm{Ma}$ (Fig. 20), correlating well with the type $6 \mathrm{~b}$ vein from the southern tip of the Teniente Dacite Porphyry dated in this study (4.718 $\pm 0.023 \mathrm{Ma})$. These dates also coincide with a molybdenite age of $4.835 \pm 0.016 \mathrm{Ma}$ from an anhydrite breccia to the north of the Braden pipe (Cannell, 2004). Although reported as a late mineralization stage breccia (Fig. 2), we suggest that this sample may actually represent a type 5 breccia associated with the Teniente Dacite Porphyry that has been overprinted by sericitic alteration. These dates also coincide with a transitional type 7a-8 vein and a previously dated type 7a vein proximal to the North Central Diorite (Maksaev et al., 2004), which yielded ages of $4.804 \pm 0.020$ and $4.83 \pm 0.03$ Ma respectively (Fig 20). These veins are, however, significantly older than a deep-level (1462 $\mathrm{m}$ asl), type 6a vein also from the margin of the North Central Diorite that yielded an age of $4.613 \pm 0.020 \mathrm{Ma}$ in this study.

Tourmaline breccias on opposite sides of the Braden pipe yield similar ages of $4.599 \pm 0.029$ and $4.584 \pm 0.020 \mathrm{Ma}$ (Fig. 20). These dates are slightly younger than the type 10 vein samples from the western edge of the Central Diorite (1754-373.8) and Southern Diorite (2083-201.2) which yield similar ages of $4.613 \pm 0.020$ and $4.698 \pm 0.023 \mathrm{Ma}(4.666 \pm 0.023 \mathrm{Ma}$ replicate). These ages are similar to a previously dated, late mineralization stage breccia associated with the latite dyke to the southwest of the Braden pipe (Fig 20; Cannell, 2004). The youngest Re-Os molybdenite dates at El Teniente are from three unusually young type 8 veins proximal to and within the Teniente Dacite Porphyry and Northern Diorite (Fig. 19) dated by Maksaev et al. (2004; see Fig. 20). 


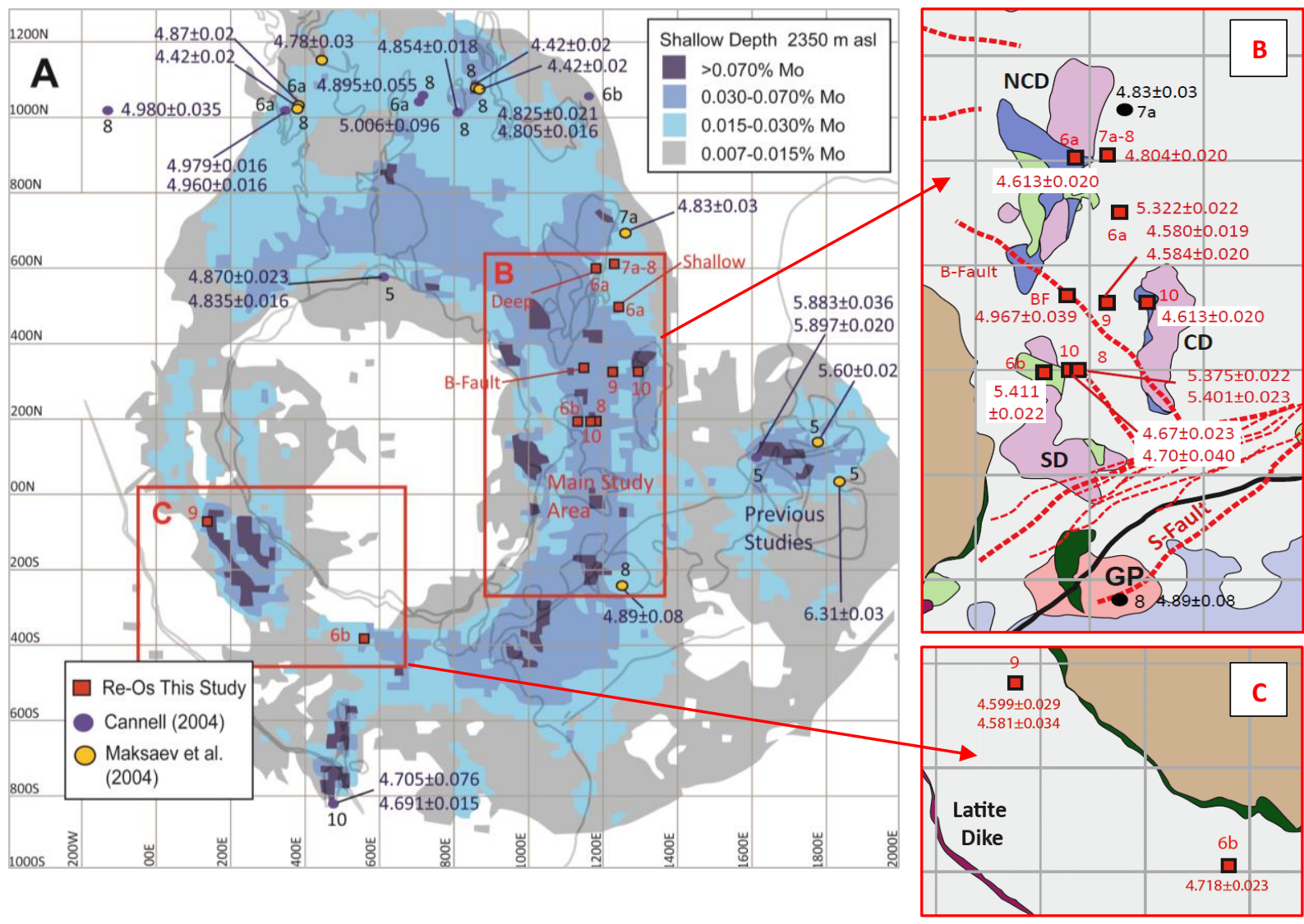

Fig. 20: (A) Molybdenite samples dated during this (red squares) and two previous studies (black circles: Cannell, 2004; Maksaev et al., 2004) superimposed on a Mo grade distribution map at mine level $2350 \mathrm{~m}$ asl. Vein and breccia types are displayed next to each sample location in accordance with the classification of Vry et al. (2010). Red boxes B and C contain samples dated during this study, the ages of which are shown on sections of geological map to the right (panels B-C). For sample descriptions and depths refer to Table 5. 
Table 5. Summary of Re-Os data for the $\mathbf{1 1}$ molybdenite samples dated during this study.

\begin{tabular}{|c|c|c|c|c|c|c|c|c|c|c|c|c|c|}
\hline Sample & $\begin{array}{l}\text { Vein } \\
\text { Type }\end{array}$ & Elev. & $\begin{array}{c}\text { Aliquot } \\
\text { Weight } \\
\text { (mg) }\end{array}$ & $\begin{array}{c}\text { Re } \\
\text { ppm }\end{array}$ & $\pm 2 \mathrm{~s}$ & $\begin{array}{c}\text { 187Re } \\
\text { ppb }\end{array}$ & $\pm 2 s$ & $\begin{array}{c}\text { 1870s } \\
\text { ppb }\end{array}$ & $\pm 2 \mathrm{~s}$ & $\begin{array}{l}\text { Total } \\
\text { common } \\
\text { Os pg }\end{array}$ & $\begin{array}{l}\text { Model } \\
\text { Age } \\
\text { (Ma) }\end{array}$ & $\begin{array}{l} \pm 2 \mathrm{~s} \\
(\mathrm{Ma})\end{array}$ & Sample Description \\
\hline 2215-119.9 & $6 a$ & 2019.5 & 1.17 & 353.4 & 0.91 & 222153 & 575 & 19.699 & 0.016 & 1.8 & 5.322 & 0.022 & $\begin{array}{l}2 \mathrm{~cm} \text { wide type } 6 \mathrm{a}-7 \mathrm{a} \text { vein containing abundant mo mineralization, } \\
\text { proximal to the North Central Diorite. Vein has no halo and minor cpy } \\
\text { mineralization ( } 2 \% \text { ). Vein minerals are } 50 \% \mathrm{qz} \text { and } 8 \% \text { anh, } 40 \% \mathrm{mo} 2 \% \\
\text { disseminated cpy. }\end{array}$ \\
\hline $\begin{array}{c}1034-837.0 \\
\text { (SEM) }\end{array}$ & $6 a$ & 1462.4 & 1.18 & 171.8 & 0.44 & 107993 & 279 & 8.301 & 0.011 & 3.3 & 4.613 & 0.020 & $\begin{array}{l}14 \mathrm{~mm} \text { wide type } 6 \text { a vein of } 80 \% \text { qz and } 5 \% \text { anh proximal to the North } \\
\text { Central Diorite at a deep mine level. Vein contains } 15 \% \text { molybdenite at } \\
\text { the center of vein. No cpy present and no discernible alteration halo. }\end{array}$ \\
\hline $2083-250.0$ & $6 b$ & 2222.9 & 1.35 & 500.5 & 1.30 & 314613 & 815 & 28.364 & 0.021 & 1.2 & 5.411 & 0.022 & $\begin{array}{l}1 \mathrm{~cm} \text { wide type } 6 \mathrm{~b} \text { vein with Mo at vein edges and cpy at vein centre in } \\
\text { the Southern Diorite. Vein is } 50 \% \mathrm{qz}, 15 \% \text { anh, } 15 \% \mathrm{mo}, 15 \% \mathrm{cpy} \text { and } 5 \% \\
\mathrm{Kfsp} \text {. No alteration halo but surrounding } 4 \mathrm{~mm} \text { contains disseminated } \\
\mathrm{cpy}\end{array}$ \\
\hline $1888-133.8$ & $6 b$ & 2177.8 & 1.21 & 183.2 & 0.47 & 115126 & 298 & 9.049 & 0.024 & 2.8 & 4.718 & 0.023 & $\begin{array}{l}\text { Large composite type } 6 \mathrm{~b} \text { vein with abundant mo and cpy mineralization } \\
\text { to the south of the Braden pipe. Vein is } 70 \% \mathrm{qz}, 5-10 \% \text { anh, } 5 \% \mathrm{cpy} \text { and } \\
15-20 \% \text { mo. Faint qz alteration halos with disseminated cpy. }\end{array}$ \\
\hline $1805-367.1$ & $7 a-8$ & 1617.7 & 1.02 & 217.2 & 0.56 & 136538 & 353 & 10.929 & 0.012 & 2.9 & 4.804 & 0.020 & $\begin{array}{l}6 \mathrm{~mm} \text { wide transitional 7a-8 vein within the TMC proximal to the North } \\
\text { Central Diorite with a diffuse qz+minor ser halo. Halo is still feldspathic } \\
\text { and is } 2 \mathrm{~mm} \text { wide. Vein is } 50 \% \mathrm{mo}, 30 \% \text { anh, } 15 \% \mathrm{qz}, 5 \% \mathrm{cpy} \text { and } 1 \% \text { bo. }\end{array}$ \\
\hline 2083-184.1 & \multirow{2}{*}{8} & 2220.6 & 0.98 & 1228.4 & 3.18 & 772118 & 1998 & 69.142 & 0.051 & 1.0 & 5.375 & 0.022 & \multirow{2}{*}{$\begin{array}{l}3 \mathrm{~mm} \text { wide mo-rich type } 8 \text { vein with a well-developed qz-ser alteration } \\
\text { halo in the TMC proximal to the Southern Diorite and Central Diorite. } \\
\text { Vein is } 45 \% \text { anh, } 10 \% \mathrm{qz} 38 \% \mathrm{mo}, 5 \% \mathrm{cpy} \text { and } 2 \% \text { bo. Alteration halo } \\
\text { contains disseminated bo, mo and cpy. }\end{array}$} \\
\hline Replicate & & 2220.6 & 0.95 & 1203.6 & 3.11 & 756483 & 1957 & 68.071 & 0.078 & 2.7 & 5.401 & 0.023 & \\
\hline $1754-285.9$ & \multirow{2}{*}{9} & 2334.4 & 2.97 & 78.75 & 0.20 & 49498 & 128 & 3.780 & 0.006 & 2.4 & 4.584 & 0.020 & \multirow{2}{*}{$\begin{array}{l}\text { Tour-mo cemented breccia sample with clusters of radiating tourmaline } \\
\text { crystals found to the East of the Braden Breccia pipe. Clasts are dacitic in } \\
\text { composition and have been aggressively altered by qz-ser }\end{array}$} \\
\hline Replicate & & 2334.4 & 2.96 & 76.50 & 0.20 & 48086 & 124 & 3.669 & 0.004 & 1.4 & 4.580 & 0.019 & \\
\hline $\begin{array}{c}2716-8.0 \\
\text { (SEM) }\end{array}$ & 9 & 2360.7 & 1.27 & 13.71 & 0.04 & 8614 & 22 & 0.660 & 0.003 & 1.5 & 4.599 & 0.029 & $\begin{array}{l}\text { Tour+mo+anh cemented breccia in the Mo-rich halo to the West of the } \\
\text { BBP. Found in association with a type } 10 \text { pyrite-carbonate vein. Breccia } \\
\text { matrix is } 32 \% \mathrm{mo}, 17 \% \text { anh, } 30 \% \text { tour, } 14 \% \mathrm{cb} 5 \% \mathrm{qz}, 2 \% \text { py. }\end{array}$ \\
\hline 2083-201.2 & \multirow{2}{*}{10} & 2221.2 & 1.37 & 49.25 & 0.13 & 30954 & 80 & 2.423 & 0.018 & 2.5 & 4.698 & 0.040 & \multirow{2}{*}{$\begin{array}{l}1 \mathrm{~cm} \text { wide anhydrite vein surrounded by type } 10 \text { qz-ser halo found in the } \\
\text { TMC on the rim of the Southern Diorite proximal to a type } 5 \text { anhydrite } \\
\text { breccia with no alteration. Vein contains } 15 \% \text { mo and }<1 \% \text { cpy } \\
\text { mineralization. No disseminated sulfides present. }\end{array}$} \\
\hline Replicate & & 2221.2 & 2.94 & 49.00 & 0.13 & 30799 & 80 & 2.394 & 0.007 & 3.6 & 4.666 & 0.023 & \\
\hline $1754-373.8$ & 10 & 2283.1 & 1.38 & 176.3 & 0.46 & 110781 & 287 & 8.515 & 0.015 & 0.7 & 4.613 & 0.020 & $\begin{array}{l}2 \mathrm{~cm} \text { wide } \mathrm{qz}+\mathrm{mo}+\mathrm{cb}+a n h \text { type } 10 \text { vein in the TMC on the western rim of } \\
\text { the Central Diorite. Vein is } 35 \% \mathrm{qz}, 15 \% \text { anh, } 25 \% \mathrm{cb} \text { and } 20 \% \mathrm{mo}, 3 \% \text { bo, } \\
1 \% \mathrm{cpy} \text { and } 1 \% \text { py. Sample has a diffuse } 6 \mathrm{~mm} \text { qz-ser halo containing } \\
\text { disseminated } \mathrm{mo} \text { and cpy. }\end{array}$ \\
\hline B-FAULT & None & 2210.0 & 1.35 & 15.69 & 0.04 & 9864 & 26 & 0.816 & 0.005 & 1.7 & 4.967 & 0.039 & $\begin{array}{l}\text { Hand sample of fine grained mo+cb+and clay minerals with slicken sides } \\
\text { associated with a large fault (B-Fault) running on a SW trend through the } \\
\text { TMC near the North Central Diorite. Minor py } 1 \% \text { present. Mo has a pale } \\
\text { blue-grey color. }\end{array}$ \\
\hline
\end{tabular}


Notes: Replicate (grey cells) = complete new analysis of existing mineral separate. SEM = Os analysis completed using a Secondary Electron Multiplier (weak signal). In these cases the replicate sample ages were assumed to be the most accurate. Elev. = Elevation of sample in meters asI. The B-Fault sample was given an estimated depth as it was not obtained from one of the studied drillcores. Sample preparation and analysis were completed at the University of Alberta Radiogenic Isotope Facility, Canada. For sample locations refer to sample dates printed on Fig. 20.

\section{Sample Re contents and validity}

Re contents are relatively high and consistent for all the main mineralization stage samples (171.8-500.5 ppm) with the exception of the type 8 vein sample, which contains highly elevated Re (1203.6-1228.4 ppm). This vein type also accounted for the highest Re concentrations recorded in the two previous Re-Os dating studies, where Re concentrations of up to 829.7 ppm were recorded (Cannell, 2004; Maksaev et al., 2004). In contrast, Re concentrations in molybdenite in the late mineralization stage veins and breccias and in the B-fault are consistently lower (13.71-176.3 ppm).

Stein et al. (2001) stated that variations in the Re contents of molybdenite are most likely to be explained by a simple mass balance phenomenon (Stein et al., 2001): as Re is highly compatible in molybdenite it will be effectively incorporated into the molybdenite crystal structure in preference to other sulfide species (Stein et al., 2001). Therefore if only minor amounts of molybdenite and abundant copper-sulfides are precipitated, the molybdenite will contain higher Re concentrations. This explains the elevated Re concentrations in molybdenite-bearing type 8 veins which, in accordance with petrographic observations and vein distribution data, are commonly associated with abundant chalcopyrite \pm bornite and only minor Mo mineralization.

In contrast to type 8 veins, mineralization in the B-Fault and in the late mineralization stage type veins and breccias is dominated by molybdenite and only minor quantities of Cu-sulfides. This means that low Re concentrations are likely to be a manifestation of Re dilution during abundant molybdenite crystallization. This is consistent with a comparison study of Re in molybdenite from the Endako porphyry Mo deposit and the Nithi Mountain occurrence, British Columbia, where lower Re concentrations at Endako were attributed to the far greater extent of Mo mineralization (Selby and Creaser, 2001). Similar observations have also been made in the Qinling belt, China (Stein et al., 1997), and in comparison studies between porphyry Cu-Mo and Mo deposits (Giles and Schilling, 1972), both of which showed decreasing Re concentrations in molybdenite deposited during Mo-rich stages. 
Suzuki et al. (2000) suggested that the Re-Os molybdenite system may be disturbed in the presence of hot, low-salinity fluids $\left(<1 \mathrm{wt} \% \mathrm{NaCl}_{\text {eq }}\right.$ ). However, a recent study by Selby and Creaser (2001) concluded that the Re-Os system is undisturbed by low to moderately saline (1-15 wt\% $\mathrm{NaCl}_{\text {eq }}$ ) hydrothermal fluids. Previous fluid inclusion microthermometric studies at El Teniente (Cannell, 2004; Klemm at al., 2007; Vry, 2010) revealed that with the exception of rare, low density, vapor-like inclusions, the majority of fluid inclusions at $\mathrm{El}$ Teniente have salinities $>1 \mathrm{wt} . \% \mathrm{NaCl}_{\text {eq. }}$. Therefore, the samples dated in this study are unlikely to have been affected by hydrothermal overprinting. This, combined with the young age of El Teniente and the fact that the Re-Os molybdenite system shows closed system behavior during ductile deformation and regional metamorphism (e.g. Stein et al., 1998; Selby and Creaser, 2001; Lawley and Selby 2012), suggests that the dates obtained during this study represent true mineralization ages.

The three replicate samples yielded ages that agree within calculated uncertainty limits (Table 5) taking into account all procedural uncertainties. The reproducibility of these sample ages suggests that the technique used was effective in producing accurate age determinations and that no samples were analyzed that contained mixed generations of molybdenite. With the exception of two samples, all calculated uncertainties are $\leq 0.023 \mathrm{Ma}$ (Table 5). However, one type 10 vein sample (2083-201.2) and the B-Fault sample have higher analytical uncertainties, mainly due to their low $\operatorname{Re}$ concentrations (Table 5). The replicate run for the type 10 vein sample yielded a lower degree of uncertainty, which was achieved by running a larger aliquot weight of molybdenite. Low Re concentrations are also documented for molybdenite in the tourmaline breccia samples from opposite sides of the Braden Breccia pipe. However, these samples yielded Re-Os ages that are within calculated uncertainties of one another as well as the tourmaline breccia replicate, thus suggesting that the technique used was effective in producing reproducible age determinations for molybdenite samples that contain very low Re concentrations. 


\section{Discussion}

\section{Geochronological constraints on the evolution of El Teniente}

Mineralized vein and breccia distributions provide strong evidence that the A-Porphyry, diorites and Teniente Dacite Porphyry all played integral roles in controlling deposit-wide grade distributions as previously proposed (e.g. Cannell et al., 2005; Vry et al., 2010). The large ranges of U-Pb zircon crystallization ages recorded for these intrusions (Fig. 3: Maksaev et al., 2004) are interpreted to reflect age determinations made on zircon antecrysts that crystallized over an extended period of time in the underlying parental magma chamber and occasional younger ages due to zircon overgrowths or post-crystallization lead-loss. We therefore infer that the youngest distributions of reliably dated, overlapping zircon ages $(1 \sigma)$ provide the best constraints for the timing of emplacement and final crystallization of each intrusion (cf. von Quadt et al., 2011).

Based on our reinterpretation of U-Pb zircon data we agree with Maksaev et al. (2004) that the crystallization of the A-Porphyry is likely to have occurred between 6.0 and $5.7 \mathrm{Ma}$ following the emplacement of the Sewell Quartz Diorite. In contrast, we suggest that crystallization of the Central and Northern Diorites is likely to have occurred between 5.6 and 5.3 Ma (Fig. 21). This window correlates with the subordinate peak in U-Pb zircon ages recorded for these intrusions (Maksaev et al., 2004) and explains the presence of molybdenite Re-Os ages of $5.411 \pm 0.022$ to $5.322 \pm 0.022 \mathrm{Ma}$ for main mineralization-type veins within and proximal to them. Based on petrological evidence and the spread of U-Pb zircon and Re-Os molybdenite ages associated with the Teniente Dacite Porphyry, we interpret a prolonged crystallization history for this unit occurring in multiple intrusionmineralization pulses between 5.1 and $4.7 \mathrm{Ma}$ (Fig. 21). This age range is younger than the weighted average ${ }^{206} \mathrm{~Pb} /{ }^{238} \mathrm{~Pb}$ age of $5.28 \pm 0.10 \mathrm{Ma}$ reported by Maksaev et al. (2004), which possibly incorporates older zircon antecrysts. A younger crystallization age between 4.6 and $4.4 \mathrm{Ma}$ is also inferred for the late dacitic dike encircling the Braden Pipe. The late formation of such dikes may explain the younger Re-Os ages of type 8 veins in the northern part of the deposit dated at $4.42 \pm$ $0.02 \mathrm{Ma}$ (Maksaev et al., 2004). Based on the overall younging of U-Pb dates from the Sewell Quartz Diorite and the A-Porphyry in the south to the Northern Diorite and the Teniente Dacite Porphyry in the North, we infer a general northward progression of the locus of magmatism over the 1.6 m.y. total lifetime of the mineralizing system. 


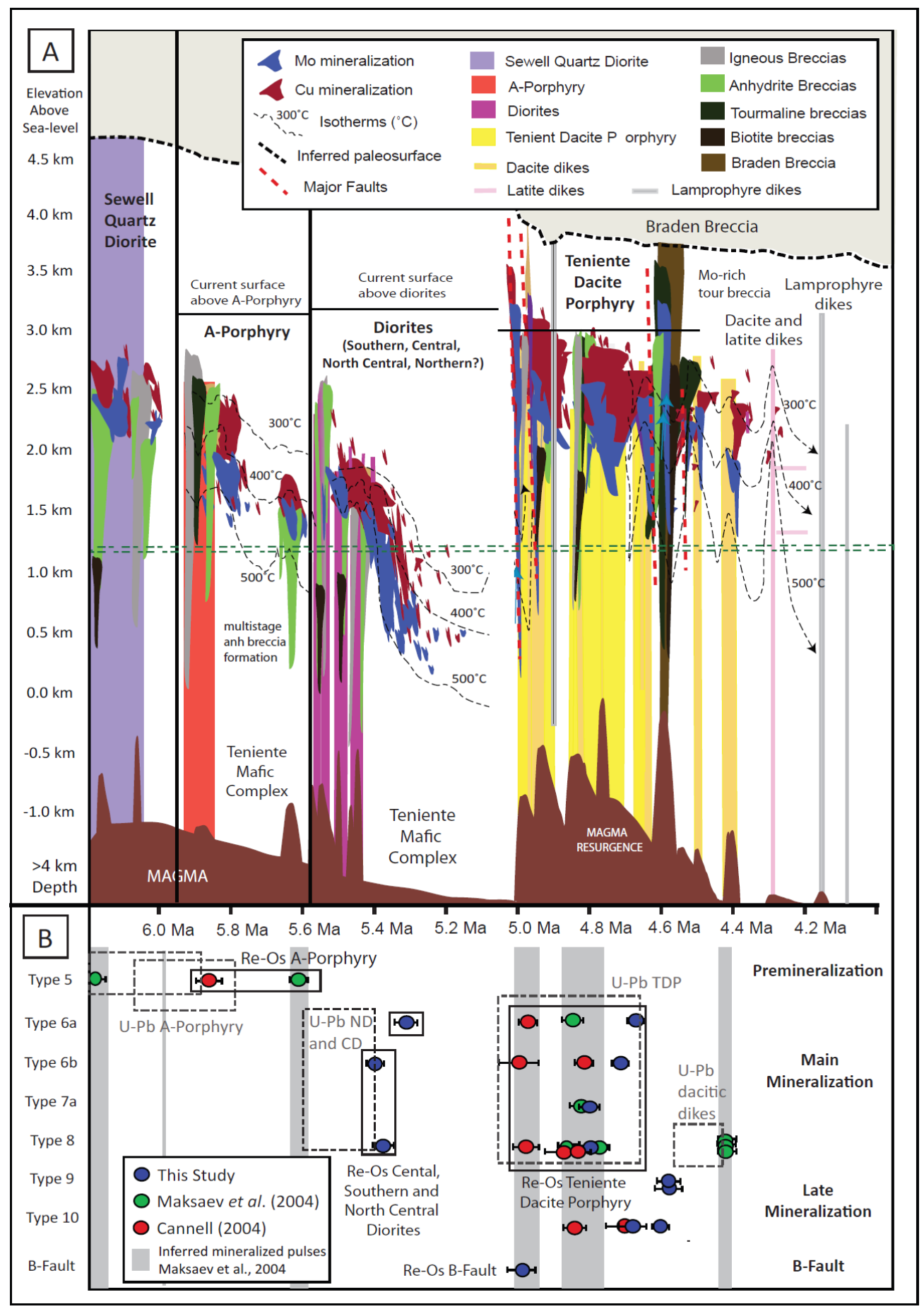

Fig. 21: (A) Time versus depth plot showing the magmatic-hydrothermal evolution of El Teniente based on field observations and geochronology. Intrusion and breccia colors match geological map (Fig. 2, 6). The positions of $\mathrm{Mo}$ and $\mathrm{Cu}$ mineralization relate to enriched ore zones $(>0.03 \% \mathrm{Mo},>1.5 \% \mathrm{Cu})$ surrounding each intrusion and are based on grade distributions, vein cross-cutting relationships and Re-Os dates collected during this and the two previous studies (Cannell, 2004; Maksaev et al., 2004). The inferred paleosurface is a conservative estimate $(\mathrm{max}=5300 \mathrm{~m}$ asl at $5 \mathrm{Ma}$ ). Dotted green line $=$ deepest drillcore depth studied, below which significant Mo grades are interpreted to extend. (B) Re-Os dates from this study (blue circles) and the two previous studies (green and red circles: see key). The five mineralizing pulses proposed by Maksaev et al. (2004) are shown in grey columns. Dotted boxes represent the youngest, reliable, overlapping U-Pb zircon dates previously obtained for each intrusion (Maksaev et al., 2004). 
The apparent correspondence between intrusion crystallization ages and $\mathrm{Re}-\mathrm{Os}$ ages determined in this and the two previous studies (Maksaev et al., 2004; Cannell et al., 2005) strongly supports the field evidence that mineralization occurred in pulses during and after the emplacement of each of the main intrusions - the A-Porphyry, diorites and during several stages of emplacement and crystallization of the Teniente Dacite Porphyry (Fig. 21; Vry et al., 2010). The relative rarity of the reverse cross-cutting vein and breccia relationships that might be expected in a system involving repeated mineralization cycles can be explained by the northward progression of magmatism (so that successive porphyries did not intrude each other), combined with the vertically elongate aspectratios of the mineralized centers (limiting lateral overprinting of one center by another).

The deposit-wide vein paragenesis and associated fluid evolution espoused in several previous studies (e.g. Cannell et al., 2005; Klemm et al., 2007) is disproved by our new Re-Os ages. For example, a type 6a-7a transitional vein between the Central Diorite and North Central Diorite has a relatively old age of $5.322 \pm 0.022 \mathrm{Ma}$, consistent with the inferred emplacement age range of the Central and Northern Diorites, whereas a deep type 6a vein from within the North Central Diorite has a significantly younger age of $4.613 \pm 0.020 \mathrm{Ma}$ (Table 5; Fig. 20). Some type 8 veins formed as early as $5.375 \pm 0.022 \mathrm{Ma}$ (proximal to the Southern Diorite), clearly before a number of type 6 and 7 veins from the northern part of the deposit dated in this and previous studies (e.g. $4.805 \pm 0.016 \mathrm{Ma}$; Cannell, 2004). Early type 8 vein development in the southern part of the system refutes the argument that there was a deposit-wide transition into sericite-stable conditions (type 8 vein stage) at $\sim 4.95 \mathrm{Ma}$ (Cannell, 2004). Sericitic alteration is the result of the dissociation of acids and the disproportionation of magmatic sulfur dioxide (e.g. Giggenbach, 1992; Rye, 1993; Heinrich et al., 2004) in response to drops in temperature and pressure (Meyer and Hemley, 1967; Reed and Rusk, 2001; Reed et al., 2005; Rusk et al., 2008). Therefore, the presence of type 8 veins of different ages within and surrounding multiple intrusions implies several distinct episodes of decreasing temperature (and/or pressure) towards the end of each mineralizing cycle (Fig. 21).

The consistent breccia and vein parageneses for the main stage of mineralization associated with each intrusion (Vry et al., 2010) are indicative of a relatively stable and fertile underlying magma chamber that fluxed geochemically similar pulses of metalliferous magmatic-hydrothermal fluids through each porphyry intrusion. The vein distribution analysis reveals that each intrusion developed similar vein halos, consisting of vein types that exhibit relatively uniform abundances and spatial configurations in each mineralized center. Combining Re-Os and U-Pb zircon ages, we interpret at least three major magmatic pulses, each separated by approximately 0.3 m.y. (Fig. 21). 
These pulses may consist of several emplacement events (as in the case of the composite Teniente Dacite Porphyry), with up to nine distinct mineralization cycles identified (Fig. 21). This interpretation is consistent with paleomagnetic data from the deposit that document complex polarity zonation, suggestive of numerous pulses of hydrothermal activity (Astudillo et al., 2010).

Molybdenite Re-Os dates from within and surrounding the Southern Diorite suggest that main mineralization-type veins associated with this intrusion formed over a relatively short timescale, within around 100,000 years (Table 5; Fig. 21). This age range is consistent with an $\sim 80,000$ year time gap between U-Pb zircon ages (closure temperature $\sim 1000^{\circ} \mathrm{C}$ ) and ${ }^{40} \mathrm{Ar} /{ }^{39} \mathrm{Ar}$ ages for hydrothermal biotite (closure temperature $\sim 300^{\circ} \mathrm{C}$ ) previously recorded for a mineralized dacitic dike at El Teniente (Maksaev et al., 2004). These age ranges are also in accordance with previous studies which concluded that the emplacement of an intrusion and the subsequent focusing of large fluid fluxes through it is likely to occur on a time scale of 10,000 to 100,000 years (Cathles, 1977, 2000; Driesner and Geiger, 2007; von Quadt et al., 2011). Relatively rapid heat loss in this environment can be attributed to significant heat advection by magmatic fluids and can explain the inward and downward overprinting of later, chalcopyrite-rich type $6 \mathrm{~b}$ and $7 \mathrm{~b}$ veins over molybdenite-rich type $6 a$ and $7 a$ veins. Thermal contraction during each mineralization cycle may also explain the overprinting of high-temperature veins by sericite-altered type 8 veins. Although type 8 veins are most abundant in distal parts of the TMC relative to the felsic-intermediate intrusions, examples were also observed overprinting type 6a veins within the mineralized intrusions and occurring at the greatest depths currently accessible.

Molybdenite Re-Os dates within and proximal to the Southern and Central Diorites cluster between 5.4 and 5.3 Ma and correlate well with crystallization ages for the Central Diorite (Maksaev et al., 2004). Unfortunately, no emplacement ages currently exist for the Southern Diorite. Significantly younger molybdenite ages of $\sim 4.8-4.6$ Ma were obtained for main mineralization-type veins within and proximal to the North Central Diorite and Northern Diorite (Fig. 20). Based on these results it is possible that these northern diorites were emplaced approximately synchronously with the Teniente Dacite Porphyry and mineralized approximately 0.6 m.y. later than the diorites further south. However, this is contradicted by relatively old zircon ages obtained from the Northern Diorite, which fall between 5.3 and $6.7 \mathrm{Ma}$. To date, no crystallization ages have been obtained for the North Central Diorite. Given this, it is currently not possible to say whether the Northern Diorite and North Central Diorite developed later. In addition it is unclear whether zircons dated in the Northern Diorite reflect final crystallization, or whether we sampled veins associated with older intrusions that 
were reactivated as hydrothermal fluid conduits during pulses of magmatism and mineralization accompanying emplacement of the Teniente Dacite Porphyry.

Mineralization within the B-fault occurred at approximately 5.0 Ma and corresponds with the oldest Re-Os dates obtained for main mineralization-type veins associated with the Teniente Dacite Porphyry (Fig. 20). This suggests that the northwest-trending faults may have developed synchronously with the emplacement of this intrusion (Fig. 21). Evidence for right-lateral, strike-slip displacement is observed along several northwest trending faults at El Teniente, including the BFault. An E-W oriented minimum principal stress is consistent with dextral strike-slip motion on these faults and the opening of the N-S fractures that accommodated emplacement of the Teniente Dacite Porphyry dike, and possibly the North Central Diorite and Northern Diorite. Thus, initiation of movement along the B-fault and related structures is interpreted to have been the trigger that rejuvenated shallow magmatism and hydrothermal activity following a hiatus of $\sim 300,000$ years (Fig. 21). The orientation of the diorite intrusions along a similar northerly trend to the Teniente Dacite Porphyry suggests that a similar tectonic trigger could have been responsible for the earlier major pulses of magmatism.

Main mineralization-type veins dated along the Teniente Dacite Porphyry dike predominantly fall between 5.00 and $4.42 \mathrm{Ma}$ (Fig. 20). This extended ( 580,000 year) period of mineralization is attributed to the fact that the Teniente Dacite Porphyry formed as a composite intrusion composed of several overlapping dikes (Fig. 21) as constrained by petrological observations, geochemical studies and previous geochronology that documents up to 1 m.y. of magmatism along the dike (Ossandón, 1974; Duarte, 2000; Skewes et al., 2002; Rojas, 2003; Maksaev et al., 2004; Cannell et al., 2005; Hitschfeld, 2006; Baker et al., 2013). The three, unusually young, type 8 veins proximal to the Teniente Dacite Porphyry and Northern Diorite (4.42 Ma: Maksaev et al., 2004) postdate all U-Pb zircon ages for the Teniente Dacite Porphyry by 0.3 m.y. (Fig. 3) but do coincide with the youngest ${ }^{40} \mathrm{Ar}-{ }^{39} \mathrm{Ar}$ sericite ages recorded in this part of the deposit. Given this we concur with Maksaev et al. (2004) that these veins represent minor, late pulses of hydrothermal activity related to the emplacement of small dacitic dikes during the waning of the magmatic system (Fig. 21).

The close spatial association of Mo-rich type 9-10 veins and breccias with the margin of the Braden Breccia pipe suggests that the late mineralization stage is closely linked to this cataclysmic event. Concentric faults and fractures surrounding the Braden Breccia pipe (Fig. 2) are interpreted to 
be the result of a period of subsidence related to magma withdrawal prior to the Braden Breccia event (Koide and Bhattacharji, 1975; Acocella et al., 2000; Cannell et al., 2005). The close spatial association of these faults with the well-defined Mo-rich halo around the Braden Breccia observed at shallow mine levels (Fig. 20) suggests that they were important in focusing late, Mo-mineralizing fluids into the upper parts of the deposit to form type 9 and 10 veins. This occurred over a relatively short time period between $4.698 \pm 0.040$ and $4.584 \pm 0.020 \mathrm{Ma}$ (Fig. 20; Table 5).

The formation of type 9 and 10 veins is likely to have been immediately followed by a major release of magmatic volatiles that formed the Braden Breccia pipe (e.g. Cannell et al., 2005). This major brecciation event cut the Mo-rich tourmaline breccias leading to the formation of a large rockflour breccia diatreme with an apparent Mo-rich marginal facies. This evolution is supported by the absence of cross-cutting type 9 veins in the Braden Breccia and the presence of considerable amounts of brecciated type 9-related tourmaline within the diatreme margins. Type 10 veins are also absent in the Braden Breccia. However, cavities and fractures within the diatreme do contain considerable amounts of coarse grained gypsum possibly generated by the ingress of circulating groundwater into the breccia pipe. U-Pb zircon ages for a ring dike linked to the formation of the Braden Breccia pipe (Maksaev et al., 2004) and K-Ar sericite dates from within and surrounding the breccia diatreme (Cuadra, 1986) led to the interpretation that this formed between 4.82 and 4.60 Ma. However, the consistent molybdenite ages in the marginal tourmaline breccias on opposing sides of the Braden Breccia pipe (4.599 \pm 0.029 and $4.584 \pm 0.020 \mathrm{Ma}$; Table 5) suggest that it was emplaced at, or shortly after, 4.6 Ma (Fig. 21).

\section{Controls on decoupling of Mo and Cu mineralization}

Based on vein and grade distribution data we agree with previous studies that approximately $80 \%$ of the $\mathrm{CU}$ at El Teniente is hosted within veins and as minor disseminations in the TMC (Camus, 1975; Vry et al., 2010) suggesting that this mafic host rock sequence is an effective physical and chemical trap for copper sulfide deposition. Approximately $10 \%$ of the $\mathrm{Cu}$ is hosted by breccias (Cannell et al., $2005,2007)$ and the remaining $10 \% \mathrm{Cu}$ occurs within the intrusions that acted as conduits for mineralizing fluids. In contrast, grade distribution data reveal that Mo grades are generally more elevated in the intrusions (e.g. Fig. 22) as well as in the cements of late mineralization stage breccias (e.g. Figs. 18-20). Based on intrusion and breccia volumes and their enriched Mo-grades relative to $\mathrm{Cu}$ at different mine levels we estimate that up to $20 \%$ of the Mo is hosted within breccias and approximately $20 \%$ is hosted within the intrusions. The remaining $60 \%$ is hosted within veins in the 
TMC, predominantly in type 6a veins surrounding each mineralized intrusion as well as in late mineralization stage veins that surround the Braden Breccia pipe at shallow mine levels.
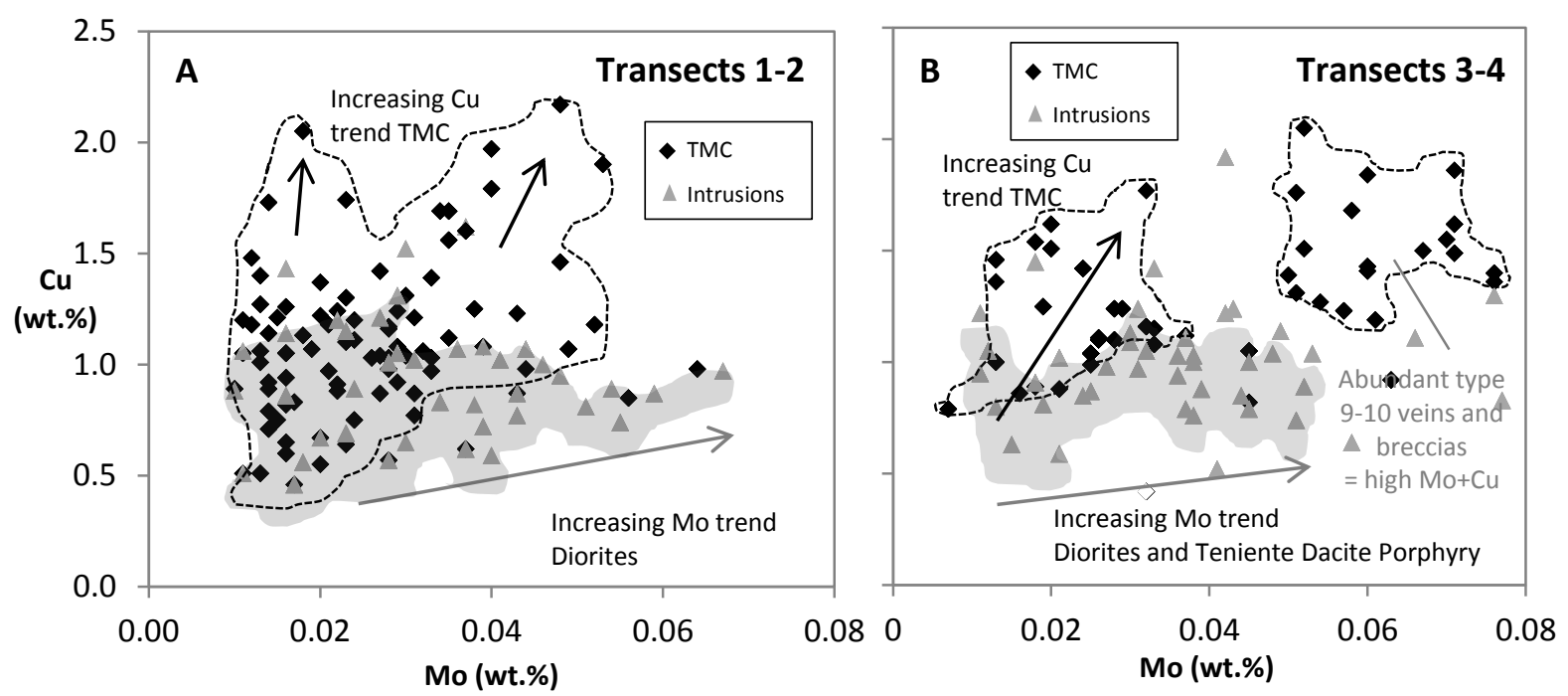

Fig. 22: Mo versus $\mathrm{Cu}$ grades (wt.\%) for different lithologies in transects 1-4. (A) Grades for six meter drillcore intervals in transects 1-2 where intrusions (grey triangles) are the Northern and North Central Diorites. (B) Mo versus $\mathrm{Cu}$ grades for 20 foot intervals in transects 3-4, where intrusions are the Teniente Dacite Porphyry and the Central and Southern Diorites. Mo:Cu ratios are generally high in the intrusions and low in the TMC.

The relative rarity of sulfide-bearing, premineralization stage veins indicates that only minor mineralization accompanied potassic alteration and biotitisation of the TMC, as previously proposed (Camus, 1975; Cuadra 1986; Maksaev et al., 2004; Cannell et al., 2005; Vry et al., 2010). The first paragenetic stage containing elevated $\mathrm{Mo}$ and $\mathrm{Cu}$ grades relates to the formation of anhydrite breccias (Table 3A-B) that cap the felsic-intermediate intrusions. Although these breccias may be well mineralized, the poor relationship between the abundance of the type 5 anhydrite veins in the surrounding vein halos and $\mathrm{Cu}$ and Mo grades (Fig. 12) suggests that most sulfides during stage 5 were precipitated proximal to the intrusions and that the ore within the surrounding $T M C$ is controlled by later main stage-type veins.

The overlap of Mo and $\mathrm{Cu}$ grade halos (e.g. Figs. 7, 8) and the comparable Re-Os dates for Mo- and Cu-rich type 6a-8 veins surrounding the porphyry intrusions (Fig. 20) suggest that both metals were deposited during the same pulses of magmatic-hydrothermal activity and are not entirely decoupled in time. Vein distribution data indicate that most Mo was precipitated in type 6a veins within and proximal to the intrusions (Fig. 13A), whereas $\mathrm{Cu}$ is principally hosted by outboard type $6 \mathrm{~b}, 7 \mathrm{~b}$ and 8 veins. The general increase in the abundance of these $\mathrm{Cu}$-rich vein types with 
distance from the felsic-intermediate intrusions, coupled with a comparable decrease in the abundance of type 6a veins (e.g. Fig. 13), can be interpreted in terms of an outward/upward transition from type $6 a$ veins into type $6 \mathrm{~b}$ and then type 7 and/or type 8 veins (Fig. 23). This considered, we suggest that main mineralization stage $\mathrm{Mo}$ and $\mathrm{Cu}$ were predominantly transported by the same fluids and were sequentially deposited leading to their decoupled mineralization shells surrounding the intrusions.

The development of Cu-rich veins from Mo-rich type 6a veins is supported by previous fluid inclusion LA-ICP-MS studies that document high $\mathrm{Mo}$ and $\mathrm{Cu}$ concentrations in fluid inclusions within type $6 a$ veins, whereas fluid inclusions in type $6 \mathrm{~b}$ and 8 veins typically remain Cu-rich but are Modepleted (Klemm et al., 2007; Vry, 2010). Cooling and consequent downward telescoping of main mineralization-type veins within each magmatic-hydrothermal cycle (Fig. 21) can explain the overprint of "later" Cu-rich veins over paragenetically "earlier" Mo-rich ones. However, it is likely that several of the main mineralization stage vein types formed synchronously at different depths and distances from the intrusions. There are several ways in which Mo-rich 6a veins may have evolved spatially into type 6b, 7a, 7b and type 8 veins (Fig. 23). Further fluid inclusion analysis of these vein types at different mine levels and distances from the intrusions is required to assess these potential evolution pathways.

Several factors are likely to have influenced Mo and Cu solubility during the development of type $6 a-8$ veins. The general restriction of Mo-rich veins to within and immediately surrounding the porphyry intrusions suggests that Mo was deposited at relatively high temperatures. Previous fluid inclusion analysis of type 6a veins suggests likely deposition temperatures in excess of $380^{\circ} \mathrm{C}$ (e.g. Vry, 2010). In contrast, the close association of Cu with type 8 veins (e.g. Fig. 14G-H) suggests that it was usually deposited at lower temperatures under which significant sericite alteration occurred. Fluid-wallrock interactions may have also played an important role in the sequential deposition of $\mathrm{Mo}$ and $\mathrm{Cu}$. As fluids migrated outwards through the TMC, interaction with reduced iron-bearing silicates is likely to have led to fluid reduction. Previous studies have demonstrated that as $\log \mathrm{fO}_{2}$ decreases below NNO+1, molybdenite saturation is favored over chalcopyrite (e.g. Audétat and Pettke, 2006; Seo et al., 2012). This could explain the early deposition of Mo in type 6a veins proximal to the intrusion margins, and the outboard deposition of chalcopyrite (Fig. 23). 


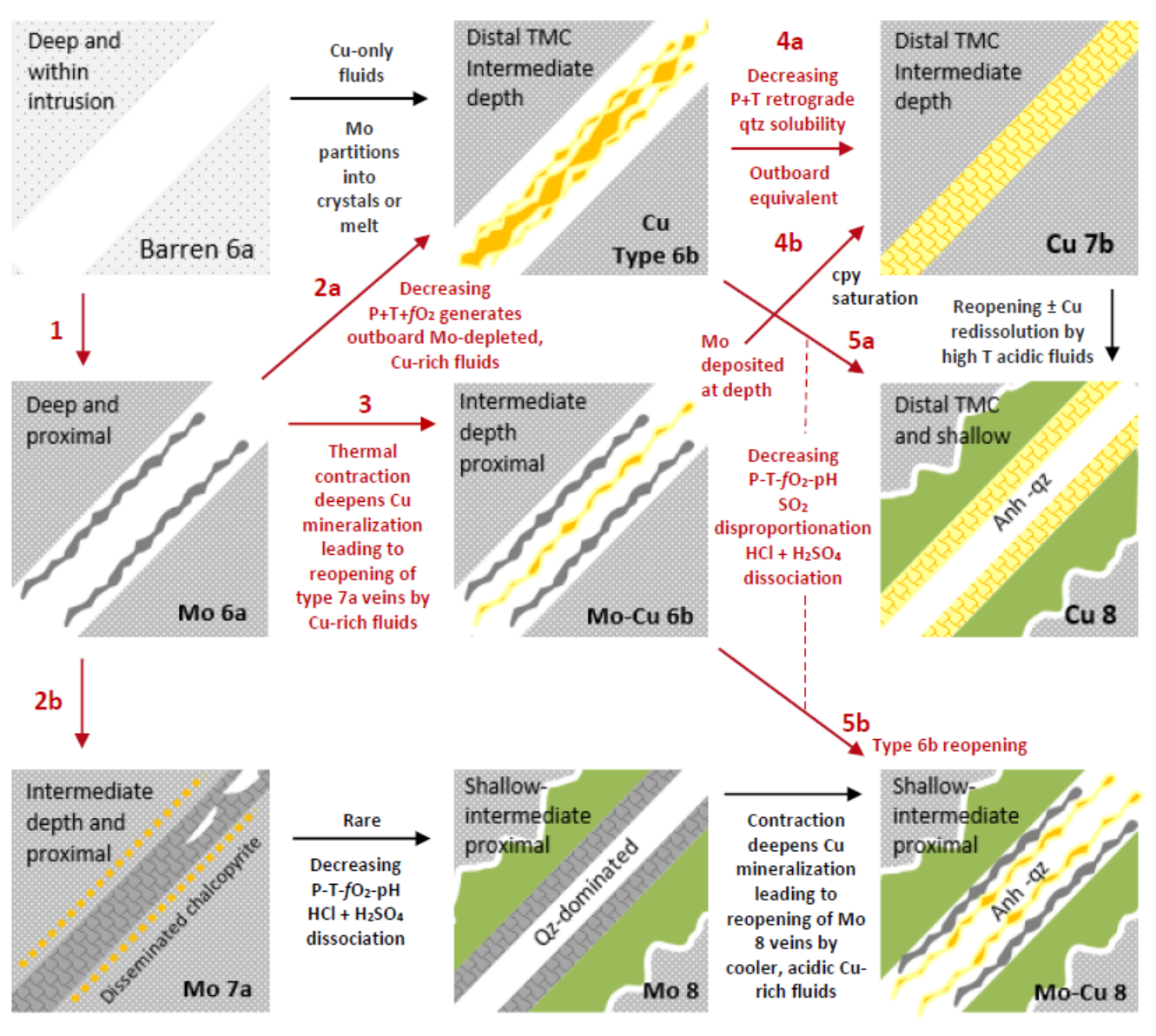

Fig. 23: Schematic diagram showing the potential spatial evolution of quartz-dominated type 6a veins into outboard Cu-rich type $6 \mathrm{~b}, 7 \mathrm{~b}$ and type 8 veins. The most likely and commonly occurring evolution pathways are shown in red (1-5b) as a function of temperature $(\mathrm{T})$, pressure $(\mathrm{P})$, oxygen fugacity $\left(\mathrm{fO}_{2}\right)$ and acidity $(\mathrm{pH})$ during the migration of fluids through the TMC. Molybdenite $=$ dark grey, Cu-sulfides (cpy $=$ chalcopyrite) $=$ yellow. Green shaded areas = quartz-sericite alteration. The typical locations of each vein type are shown in the top left of each diagram: Proximal $=<50 \mathrm{~m}$ from intrusion, distal $=>50 \mathrm{~m}$ from intrusion.

The formation of the relatively rare type $7 a$ molybdenite veins can be explained by upward/outward adiabatic flow down pressure gradients leading to retrograde quartz solubility (e.g. Vry et al., 2010). The fact that the type 7a veins are commonly surrounded by significant disseminated chalcopyrite suggests that they were formed from $\mathrm{Cu}$-bearing fluids, with relatively high temperature and $\mathrm{fO}_{2}$ conditions inhibiting $\mathrm{Cu}$-precipitation proximal to the intrusions. Alternatively, the formation of type 7a veins could be the result of the exsolution of separate pulses of Mo-rich and relatively Cu-poor fluids from the magmatic source. Further fluid inclusion analysis is required to test this hypothesis.

The presence of numerous, thick, type $7 \mathrm{~b}$ veins within the TMC suggests that fluid-wallrock interactions played an important role in triggering the precipitation of chalcopyrite (Fig. 23). 
However, previous fluid inclusion studies also revealed an apparent increase in the abundance of boiling assemblages in Cu-rich type 6b-8 veins (Cannell, 2004; Klemm et al., 2007; Vry, 2010), so that vapor-brine partitioning may also have played a role in $\mathrm{Cu}$ deposition, perhaps via loss of sulfur species to the low density vapor and consequent destabilization of $\mathrm{Cu}$-sulfide complexes. The comparative rarity of brine-vapor assemblages reported in Mo-rich type 6a veins suggests that vapor-brine separation was less likely to have been important in controlling Mo deposition.

Type 8 veins display the strongest decoupling between Mo and $\mathrm{Cu}$ grades of any main mineralization-type vein (Figs. 14G-H, 15G-H). The rarity of type 8 veins containing molybdenite, and the fact that these rare examples commonly contain unaltered feldspars in their alteration halos, suggests that most Mo was deposited prior to significant acid dissociation, whereas $\mathrm{Cu}$ was frequently deposited under cooler and more acidic conditions (Fig. 23). A detailed fluid inclusion LAICP-MS study is currently underway to test the proposed vein evolution model and to assess the conditions under which $\mathrm{Mo}$ and $\mathrm{Cu}$ were deposited as hydrothermal fluids migrated outward from each intrusion.

The abundance of Cu-sulfide (especially bornite)-bearing main mineralization-type veins surrounding the Teniente Dacite Porphyry suggests that this intrusion was responsible for much of the shallow level Cu mineralization in this part of the deposit (Cuadra, 1975; Maksaev et al., 2004; Cannell et al., 2005; Vry et al., 2010). In contrast, Mo grades in this area are strongly controlled by late mineralization stage veins and breccias that overprint $\mathrm{Cu}$ mineralization and which have been dated at approximately 4.6 Ma (Fig. 20). The relatively Cu-poor nature of late mineralization stage veins and breccias is interpreted to be the result of the earlier extraction of $\mathrm{Cu}$ from the underlying magma chamber by previous cycles of release of S-rich magmatic fluids (e.g. Zajacz and Halter, 2009). This could have created a Cu-poor residual melt that became progressively enriched in incompatible Mo during the final stages of crystallization (e.g. Candela and Holland, 1984; Audétat, 2010).

The late exsolution of Mo-rich fluids from a highly fractionated magma chamber could explain why Mo grades associated with late mineralization stage veins and breccias are typically two to three times higher than those associated with main mineralization stage veins. Late pulses of deep-sourced, oxidized, Mo-rich fluids may have exploited recently-opened faults to form the concentric and northwest-trending configuration of anhydrite-dominated, late mineralization stage veins and breccias at shallow mine levels. This focusing of Mo into structural traps may explain the 
unusually high Mo grades of up to 0.35 wt.\% recorded in some drillcore intersections at shallow mine levels. Alternatively, Mo may have been significantly enriched by remobilization as previously suggested (Vry et al., 2010). Mo remobilization could explain the apparent rarity of Mo-rich main mineralization stage veins associated with the Teniente Dacite Porphyry which, according to the proposed model of transitional vein development, should occur below Cu-rich veins in this part of the deposit. In addition, this process may explain why peak Mo grades occur slightly outboard of the Braden Breccia pipe margin. Although both mechanisms are possible, the physical and chemical characteristics of late mineralization stage fluids remain poorly constrained. Further fluid inclusion studies are required to identify the origin and reasons for the high Mo contents of these late stage fluids, which, to-date have not been studied in detail.

Summing up, the combination of geochronological, vein distribution and grade data suggest that magmatic processes probably do not control the spatial and temporal decoupling of $\mathrm{Cu}$ and Mo at El Teniente, although the late, high Mo grades could be attributed to the long-term evolution of Mo: $\mathrm{Cu}$ ratios in the underlying magma reservoir. In general, $\mathrm{Cu}$ and Mo were probably transported by the same fluids, with their tendency to precipitate in distinct vein types being related to varying temperature, pressure (e.g. Ulrich et al., 2002; Redmond et al., 2004; Landtwing et al., 2005; Ulrich and Mavrogenes, 2008; Rusk et al., 2008) and redox state of fluids (e.g. Phillips et al., 1974; Sillitoe 2010; Seo et al., 2012) as they exited the porphyry intrusive conduits and migrated out into fractured mafic rocks of the TMC. 


\section{Conclusions}

Combined grade and vein distribution analysis and high-precision Re-Os dating at El Teniente provide valuable insights into the genetic links between different intrusions, breccias and vein types and enable a quantitative assessment of their importance with respect to economic mineralization. $\mathrm{Mo}$ and $\mathrm{Cu}$ grades both show a strong spatial-temporal relationship with the A-Porphyry, diorites and Teniente Dacite Porphyry, which acted as conduits for pulses of magmatic-hydrothermal fluids. These each developed their own, relatively localized, main mineralization-type vein halos that closely followed the same breccia and vein chronology. Re-Os dating provides evidence that there was no single, deposit-wide evolution in vein types and their associated fluids as previously proposed. Results are indicative of the systematic development of relatively localized ore shells surrounding each intrusion which developed during and immediately after their crystallization. Intrusion-mineralization pulses appear to be relatively short-lived ( $<100,000$ years), with more prolonged mineralization surrounding the Teniente Dacite Porphyry attributed to its extended intrusion history. The emplacement of this northward-trending intrusion is likely linked to the development of northwest trending faults that underwent dextral strike slip displacement at approximately 5.0 Ma. Individual pulses of magmatic-hydrothermal activity are separated by quiescent periods of up to 300,000 years, documented by distinct gaps in the ages of shallow level molybdenite mineralization.

Vein distribution analysis reveals that type 6a quartz-molybdenite veins are the most important control on deposit-wide Mo grade distributions. The importance of these veins is particularly notable in close proximity to the felsic-intermediate intrusions and at deep mine levels, where their abundance controls typical grades of 0.01 to 0.06 wt.\% Mo. In contrast, Cu grades of up to 2.4 wt.\% are principally controlled by the abundances of type $6 \mathrm{~b}, 7 \mathrm{~b}$ and 8 veins that occur in more distal positions relative to the porphyry intrusions. These vein types appear to be upward and outward transitional veins from higher temperature 6a veins, suggesting that sequential deposition of metals, as a result of decreasing temperature and $\mathrm{fO}_{2}$, was the main driving force in Mo-Cu decoupling during each cycle of main mineralization-type veining.

Mo grades $>0.06 \mathrm{wt} . \%$ are controlled by the presence of late mineralization stage veins and breccias that show a close spatial association with faults and fractures surrounding the Braden pipe at shallow mine levels. The generally Cu-poor nature of this paragenetic stage is attributed to the prior preferential extraction of $\mathrm{Cu}$ from the underlying magma chamber in the previous mineralizing events. This led to the development of a Mo-rich residual melt phase that exsolved oxidized, Mo-rich 
fluids that overprinted Cu mineralization at approximately 4.60 Ma. During this event, remobilization of Mo may have also increased Mo concentrations in late mineralization stage fluids, explaining the apparent lack of molybdenite-bearing main mineralization-type veins at depth proximal to the Teniente Dacite Porphyry. The late mineralization stage was terminated by the formation of the Braden Breccia pipe in a single explosive event at approximately 4.58 Ma. With the exception of minor mineralization associated with small dacitic dikes, this event marked the termination of Mo and $\mathrm{Cu}$-sulfide deposition at the deposit.

\section{Acknowledgments}

We are extremely grateful to the members of CODELCO Superintendencia de Geología, El Teniente, especially Patricio Zuñiga and Felipe Celhay, Superintendents for providing access to the mine, drillcore samples, grade data and valuable insights into the geological evolution of El Teniente. We would also like to thank CODELCO Division El Teniente for granting permission to publish this study. We also appreciate the invitation of the University of Alberta Radiogenic Isotope Facility and the assistance of Barbara Ziger, Mark Simms and Krystle Moore in completing the Re-Os molybdenite dating study. We would like to acknowledge Imperial College London, Department of Earth Science and Engineering, for granting a Ph.D. scholarship to the primary author, and the Institute of Materials, Minerals and Mining (IOM3 bursary) and the Society of Economic Geologists (Hugh E. McKinstry Fund) for external financial support that made this study possible. Finally, we would like to thank Chris Lawley, John Walshe, Jeremy Richards and Larry Meinert for their thorough and constructive reviews of the draft manuscript. 


\section{References}

Acocella, V., Cifelli, F., and Funiciello, R., 2000, Analogue models of collapse calderas and resurgent domes: Journal of Volcanology and Geothermal Research, v. 104, p. 81-96.

Arévalo, A., and Floody, R., 1995, Estúdio Geometallúrgico del mineral a explotar a mediano y largo plazo. Chapter 1, Modelo Global de Alteración y Mineralización: Internal report, Superintendencia de Geología, El Teniente, CODELCO-Chile, p. 16.

Astudillo, N., Roperch, P., Townley, B., Arriagada, C., and Chauvin, A., 2010, Magnetic polarity zonation within the El Teniente copper-molybdenum porphyry deposit, central Chile: Mineralium Deposita, v. 45, p. 23-41.

Audétat, A., 2010, Source and evolution of molybdenum in the porphyry Mo(-Nb) deposit at Cave Peak, Texas: Journal of Petrology. v. 51, p. 1739-1760.

Audétat, A., and Pettke T., 2006, Evolution of a porphyry-Cu mineralized magma system at Santa Rita, New Mexico (USA): Journal of Petrology, v. 47, p. 2021-2046.

Baker, M.J., Hollings, P.N., and Cooke, D.R., 2013, Development of fertile magma at El Teniente, Chile: implications for porphyry-style mineralisation [abs]: Goldschmidt Conference, 23 ${ }^{\text {rd }}$, Florence, Italy, 25-30 August 2013, Abstract Volume, p. 645.

Ballard, J.R., Palin, J.M., Williams, I.S., Campbell, I.H., and Faunes, A., 2001, Two ages of porphyry intrusion resolved for the super-giant Chuquicamata copper deposit of northern Chile by ELA-ICP-MS and SHRIMP: Geology, v. 29, p. 383-386.

Bingen, B., and Stein, H., 2003, Molybdenite Re-Os dating of biotite dehydration melting in the Rogaland high-temperature granulites, S Norway: Earth and Planetary Science Letters, v. 208, p. 181-195.

Bingen, B., Davis, W.J., Hamilton, M.A., Engvik, A.K., Stein, H.J., Skar, O., and Nordgulen, O., 2008, Geochronology of highgrade metamorphism in the Sveconorwegian nelt, S. Norway; U-Pb, Th-Pb, and Re-Os data: Norwegian Journal of Geology, v. 88, p. $12-42$

Camus, F., 1975, Geology of the El Teniente orebody with emphasis on wallrock alteration: Economic Geology, v. 70, p. 1341-1372.

Camus, F., 2002, The Andean Porphyry Systems. In Porter, T. M., Ed., Super Porphyry Copper and Gold Deposits: A Global Perspective, $1^{\text {st }}$ ed.: Adelaide, PGC Publishing, p.45-63.

Candela, P.A., and Holland, H.D., 1984, The partitioning of copper and molybdenum between silicate melts and aqueous fluids: Geochimica et Cosmochimica Acta, v. 48, p. 373-380.

Cannell, J., 2004, El Teniente porphyry copper-molybdenum deposit, central Chile: Unpublished Ph.D. thesis, Hobart, Australia, University of Tasmania, $299 \mathrm{p}$.

Cannell, J., Cooke, D.R., Walshe, J.L., and Stein, H., 2005, Geology, mineralization, alteration, and structural evolution of the El Teniente porphyry Cu-Mo deposit: Economic Geology, v. 100, p. 979-1003.

Cannell, J., Cooke, D.R., Walshe, J.L., and Stein, H., 2007, Geology, mineralization, alteration and structural evolution of the El Teniente porphyry Cu-Mo deposit - a reply: Economic Geology, v. 102, p. 1171-1180.

Carroll, M.R., and Rutherford, M.J., 1988, Sulfur speciation in hydrous experimental glasses of varying oxidation state: Results from measured wavelength shifts of sulfur X-rays: American Mineralogist, v. 73, p. 845-849.

Cathles, L.M., 1977, An analysis of the cooling of intrusives by ground-water convection which includes boiling: Economic Geology and the Bulletin of the Society of Economic Geologists, v. 72, p. 804-826.

Charrier, R., Baeza, O., Elgueta, S., Flynn, J.J., Gans, P., Kay, S.M., Muñoz, N., Wyss, A.R., and Zurita, E., 2002, Evidence for Cenozoic extensional basin development and tectonic inversion south of the flat-slab segment, southern central Andes, Chile ( $33^{\circ}-36^{\circ}$ S): Journal of South American Earth Sciences, v. 15, p. 117-139.

Clark, A.H., Farrar, E., Camus, F., and Quirt, S., 1983, K-Ar age data for the El Teniente porphyry copper deposit, central Chile: Economic Geology, v. 78, p. 1003-1006. 
Cloos, M., 2001, Bubbling magma chambers, cupolas, and porphyry copper deposits: International Geology Review, v. 43, p. 285-311.

Creaser, R.A., and Selby, D., 2002, Re-Os molybdenite analysis-Considerations for accurate and reproducible dates [abs]:, Goldschmidt Conference, $12^{\text {th }}$, Davos, Switzerland, $18^{\text {th }}-23^{\text {rd }}$ August 2002, Abstract Volume, p. A156.

Cuadra, P.C., 1986, Geochronologia K-Ar del yacimiento El Teniente y areas adyacentes: Revista Geológica de Chile, v. 27, p. 3-26.

Duarte, P.O., 2000, Caracterización geológica y geotécnica del pórfido dacitico El Teniente: Unpublished Honours thesis, Santiago, Chile, Universidad de Chile, $80 \mathrm{p}$.

Giggenbach, W.F., 1992, Magma degassing and mineral deposition in hydrothermal systems along convergent plate boundaries: Economic Geology, v. 87, p. 1927-1944.

Giles, D. L., and Schilling, J. H., 1972, Variation in rhenium content of molybdenite: International Geological Congress, 24th, Montreal, Proceedings, v. 10, p. 145-152.

González, R. A., 2006, Petrografía geoquímica y microtermometría de los intrusivos félsicos del sector norte del yacimiento El Teniente. Unpublished Memoria de Título, Concepción, Chile, Universidad de Concepción, 140 p.

Geisler, T., Ulonska, M., Schleicher, H., Pidgeon, R.T., and Van Bronswijk, W., 2001, Leaching and differential recrystallization of metamict zircon under experimental hydrothermal conditions: Contributions to Mineralogy and Petrology, v. 141, p. 53-65.

Gustafson, L.B., and Hunt, J.P., 1975, The porphyry copper deposit at El Salvador, Chile: Economic Geology, v. 70, p. 857-912.

Harris, A.C., Dunlap, W.J., Reiners, P.W., Allen, C.M., Cooke, D.R., White, N.C., Campbell, I.H., and Golding, S.D., 2008, Multimillion year thermal history of a porphyry copper deposit: Application of U-Pb, 40Ar/39Ar and (U-Th)/He chronometers, Bajo de la Alumbrera copper-gold deposit, Argentina: Mineralium Deposita, v. 43, p. 295-314.

Hernández, E., Letelier, C., Letelier, O., Mestre, A., and Portigliati, C., 1980, Geología, distribución y cálculo de reservas de molibdeno en El Teniente: Anales del Congreso del Cincuentenario 1930-1980, Minería de cobres porfíricos: Santiago, Chile, Instituto de Ingenieros de Minas, v. 2, p. 364-383.

Heinrich, C.A., Driesner, T., Stefansson, A., and Seward, T.M., 2004, Magmatic vapor contraction and the transport of gold from the porphyry environment to epithermal ore deposits: Geology, v. 32, p. 761-764.

Hitschfeld, M., 2006, Petrografía y geoquímica de los intrusivos leucocráticos del sector sur este del yacimento El Teniente, VI region, Chile: Unpublished Honours thesis, Concepción, Chile, Universidad de Concepción, 120 p.

Howell, F.H., and Molloy, J.S., 1960, Geology of the Braden orebody, Chile, South America: Economic Geology, v. 55, p. 863-905.

Klemm, L.M., Pettke, T., Heinrich, C.A., and Campos, E., 2007, Hydrothermal evolution of the El Teniente deposit, Chile: Porphyry Cu-Mo ore deposition from low-salinity magmatic fluids: Economic Geology, v. 102, p. 1021-1045.

Koide, H., and Bhattacharji, S., 1975, Formation of fractures around magmatic intrusions and their role in ore localization: Economic Geology, v. 70, p. 781-799.

Kudrin, A.V., 1989, Behavior of $\mathrm{Mo}$ in aqueous $\mathrm{NaCl}$ and $\mathrm{KCl}$ solutions at $300-450^{\circ} \mathrm{C}$ : Geochemistry International, $26, \mathrm{p}$. 87-99.

Kurtz, A. C., Kay, S. M., Charrier, R., and Farrar, E., 1997, Geochronology of Miocene plutons and exhumation history of the El Teniente region, Central Chile (34-35 S): Revista Geológica de Chile, v.16, p.145-162.

Landtwing, M.R., Pettke, T., Halter, W.E., Heinrich, C.A., Redmond, P.B., Einaudi, M.T., and Kunze, K., 2005, Copper deposition during quartz dissolution by cooling magmatic- hydrothermal fluids: the Bingham porphyry: Earth and Planetary Science Letters, v. 235, p. 229-243. 
Landtwing, M.R., Furrer, C., Redmond, P.B., Pettke, T., Guillong, M., and Heinrich, C.A., 2010, The Bingham Canyon porphyry $\mathrm{Cu}-\mathrm{Mo}-\mathrm{Au}$ deposit. III. Zoned copper-gold ore deposition by magmatic vapor expansion: Economic Geology, v. 105, p. 91-118.

Lawley, C.J.M., and Selby, D., 2012, Re-Os geochronology of quartz-enclosed ultrafine molybdenite: Implications for ore deposit geology: Economic Geology, v. 107, p. 1499-1505.

Lindgren, W., and Bastin, E. S., 1922, Geology of the Braden mine, Rancagua, Chile: Economic Geology, v. 17, p. 863-905.

Maksaev, V., Munizaga, F., McWilliams, M., Fannning, M., Mathur, R., Ruiz, J., and Zentilli, M., 2004, New chronology for El Teniente, Chilean Andes, from U-Pb, 40Ar/39Ar, Re-Os, and fission-track dating: Implications for the evolution of a supergiant porphyry Cu-Mo deposit: Society of Economic Geologists Special Publication 11, p. 15-54.

Maksaev, V., Munizaga, F., Zentilli, M., and Charier, R., 2009, Fission track thermochronology of Neogene plutons in the Principal Andean Cordillera of central Chile $\left(33-35^{\circ} \mathrm{S}\right)$ : Implications for tectonic evolution and porphyry Cu-Mo mineralization, Andean Geology, v. 36, p. 153-171.

Markey, R., Stein, H.J., Hannah, J.L., Selby, D. and Creaser, R.A., 2007, Standardizing Re-Os geochronology: A new molybdenite Reference Material (Henderson, USA) and the stoichiometry of Os salts: Chemical Geology, v. 244, p. 74-87.

Meyer, C., and Hemley, J.J., 1967, Wall rock alteration, in: Barnes, H.L., ed., Geochemistry of Hydrothermal Ore Deposits. New York, Holt, Rinehart and Winston, Inc., p. 166-232.

Muñoz, M., Charrier, R., Fanning, C.M., Maksaev, V., and Deckart, K., 2012, Zircon trace element and O-Hf isotope analyses of mineralized intrusions from El Teniente ore deposit, Chilean Andes: constraints on the Source and magmatic evolution of porphyry Cu-Mo related magmas: Journal of Petrology, v. 53, p. 1091-1122.

Ootes, L., Lentz, D.R., Creaser, R.A., Ketchum, J.W.F., and Falck, H., 2007, Re-Os molybdenite ages from the Archean Yellowknife greenstone belt: Comparison to U-Pb ages and evidence for metal introduction at $2675 \mathrm{Ma}$ : Economic Geology, v. 102, p. 511-518.

Ossandón, G., 1974, Petrografía y alteración del Pórfido Dacitico, yacimiento El Teniente: Unpublished Honours thesis, Santiago, Chile, Universidad de Chile, p. 112.

Pettke, T., Oberli, F., and Heinrich, C.A., 2010, The magma and metal source of giant porphyry-type ore deposits, based on lead isotope microanalysis of individual fluid inclusions: Earth and Planetary Science Letters, v. 296, 267-277.

Phillips, C.H., Gambell, N.A., and Fountain, D.S., 1974, Hydrothermal alteration, mineralization, and zoning in the Ray deposit: Economic Geology, v. 69, p. 1237-1250.

Proffett, J.M., 2003, Geology of the Bajo de la Alumbrera porphyry copper-gold deposit, Argentina: Economic Geology and the Bulletin of the Society of Economic Geologists, v. 98, p. 1535-1574.

Quirt, S., 1972, A potassium argon investigation of the Andean mobile belt of North and Central Chile: Unpublished Ph.D. thesis, Kingston, Ontario, Canada, Queens University, $240 \mathrm{p}$.

Rabbia, O. M., Hernández, L. B., French, D. H., King, R. W. and Ayers, J. C., 2009, The El Teniente Cu-Mo deposit from a hydrothermal rutile perspective: Mineralium Deposita, v. 44, p. 849-866.

Redmond, P.B., Einaudi, M.T., Inan, E.E., Landtwing, M.R., and Heinrich, C.A., 2004, Copper deposition by fluid cooling in intrusion-centered systems: New insights from the Bingham porphyry ore deposits, Utah: Geology, v. 32, p. 217-220.

Redmond, P.B., and Einaudi, M.T., 2010, The Bingham Canyon porphyry Cu-Mo-Au deposit. I. Sequence of intrusions, vein formation, and sulfide deposition: Economic Geology and the Bulletin of the Society of Economic Geologists, v. 105, p. 43-68.

Reed, M., and Rusk, B., 2001, Insights into supercritical hydrothermal processes from numerical models of potassic hydrothermal alteration, and SEM-CL imaging of vein quartz at Butte, Montana, in Toshiyuki, H., ed., Proceedings from the Workshop on Potential Thermal Extraction from Deep-seated Rock Masses: Sendai, Japan, Tohoku University, p. 37-53.

Reed, M.H., Rusk, B., Palandri, J., and Dilles, J., 2005, The Butte hydrothermal system: One magmatic fluid yielded all vein types [abs]: Geological Society of America Abstracts with Programs, v. 37, p. A315. 
Richards, J.P., 2003, Tectono-magmatic precursors for porphyry Cu-(Mo-Au) deposit formation: Economic Geology and the Bulletin of the Society of Economic Geologists, v. 98, p. 1515-1533.

Rivera, O., and Falcón, M. F., 1998, Estudio Geológico distrital de la división El Teniente de CODELCO-Chile, Escala 1:25 000: Internal report, Superintendencia de Geología, El Teniente, CODELCO-Chile, p. 200.

Rojas, A., 2002, Petrografía y geoquímica del pórfido dacitico Teniente, yacimiento El Teniente, Provincia de Cachapoal, VI Región, Chile: Unpublished Honours thesis, Concepción, Chile, Universidad de Concepción, p. 118.

Rojas, A., 2003, Porfido Teniente: Dos fases intrusivas caracteristicas geológicas, petrográficas y geoquímicas, yacimiento El Teniente [abs]: Congreso Geológico Chileno, 10th, Concepción, Chile, 2003, Abstract volume, p. 9.

Rusk, B.G., Reed, M.H., and Dilles, J.H., 2008, Fluid inclusion evidence for magmatic-hydrothermal fluid evolution in the porphyry copper-molybdenum deposit at Butte, Montana: Economic Geology, v. 103, p. 307-334.

Rye, R.O., 1993, The evolution of magmatic fluids in the epithermal environment: the stable isotope perspective: Economic Geology, v. 88, p. 733-753.

Seedorff, E., Dilles, J.H., Proffett, J.M., Einaudi, M.T., Zurcher, L., Stavast, W.J.A., Johnson, D.A., and Barton, M.D., 2005, Porphyry deposits: Characteristics and origin of hypogene features: Economic Geology $100^{\text {th }}$ Anniversary Volume, $p$. 251-298.

Seguel, J., Arévalo, A., and Skewes, M.A., 2006, Complejo de brechas hidrotermales en el flanco este de Mina El Teniente: Congreso Geológico Chileno, $11^{\text {th }}$, Antofagasta, Actas, v. 2, p. 351-354.

Selby, D., and Creaser, R.A., 2001, Re-Os geochronology and systematics in molybdenite from the Endako porphyry molybdenum deposit, British Columbia, Canada: Economic Geology, v. 96, p. 197-204.

Selby, D., and Creaser, R.A., 2004, Macroscale NTIMS and microscale LA-MC-ICP-MS Re-Os isotopic analysis of molybdenite; testing spatial restrictions for reliable Re-Os age determinations, and implications for the decoupling of Re and Os within molybdenite: Geochimica et Cosmochimica Acta, v. 68, p. 3897-3908.

Seo, J.H., Guillong, M., and Heinrich, C.A., 2012, Separation of Molybdenum and Copper in Porphyry Deposits: The Roles of Sulfur, Redox, and pH in Ore Mineral Deposition at Bingham Canyon: Economic Geology, v. 107, p. 333-356.

Sillitoe, R.H., 2010, Porphyry copper systems: Economic Geology, v. 105, p. 3-41.

Skewes, A.M., Arévalo, A., Floody, R., Zuñiga, P.H., and Stern, C., 2002, The giant El Teniente breccia deposit: Hypogene copper distribution and emplacement: Society of Economic Geologists Special Publications, v. 9, p. 299-332.

Skewes, A., Arévalo, A., Floody, R., Zuñiga, P.H., and Stern, C., 2005, The El Teniente megabreccia deposit: The world's largest copper deposit, in Porter, T.M., ed., Super porphyry copper and gold deposits - a global perspective: Adelaide, Australia, Porter Geoscience Consultancy Publishing, v. 1, p. 83-114.

Skewes, A., and Holmgren, C., 1993, Solevantamiento andino, erosión y emplazamiento de brechas mineralizadas en el depósito de cobre porfídico Los Bronces, Chile Centrál $\left(33^{\circ} \mathrm{S}\right)$ : Applicación de geotermometria de inclusions fluidas: Revista Geólogica de Chile, v. 20, p. 71-83.

Skewes, A., and Stern, C.R., 1995, Genesis of the giant Late Miocene to Pliocene copper deposits of central Chile in the context of Andean magmatic and tectonic evolution: International Geology Review, v. 37, p. 71-84.

Skewes, A., and Stern, C.R., 2007, Geology, mineralization, alteration and structural evolution of El Teniente porphyry CuMo deposit - a discussion: Economic Geology, v. 102, p. 1165-1170.

Smoliar, M.I., Walker, R.J., and Morgan, J.W., 1996, Re-Os ages of Group IIA, IIIA, IVA, and IVB iron meteorites: Science, v. 271, p. 1099-1102.

Stein H. J., Markey R. J., Morgan J. W., Du A., and Sun Y., 1997, Highly precise and accurate Re-Os ages for molybdenite from the East Qinling molybdenum belt, Shaanxi province, China: Economic Geology, v. 92, p. 827-835.

Stein, H.J., Sundbland, K., Markey, R.J., Morgan, J.W., and Motuza, G., 1998, Re-Os ages for Archean molybdenite and pyrite, Kuittila-Kivisuo, Finland and Proterozoic molybdenite, Kabeliai, Lithuania; testing the chronometer in a metamorphic and metasomatic setting: Mineralium Deposita, v. 33, p. 329-345. 
Stein, H. J., Markey, R. J., Morgan, J. W., Hannah, J.L., and Scherstén, A., 2001, The remarkable Re-Os chronometer in molybdenite: how and why it works, Terra Nova, v 13, p. 479-486.

Stein, H.J., and Bingen, B., 2002, 1.05-1.01 Ga Sveconorwegian metamorphism and deformation of the supracrustal sequence at Saesvatn, South Norway: Re-Os dating of Cu-Mo mineral occurrences: Geological Society of London Special Publication, v. 204, p. 319-335.

Stern, C.R., 1989, Pliocene to present migration of the volcanic front, Andean Southern Volcanic Zone: Revista Geológica de Chile, v. 16, p. 145-162.

Stern, C.R., 1991, Role of subduction erosion in the generation of Andean magmas: Geology, v. 19, p. 78-81.

Stern, C. R., and Skewes, M. A., 2005, Origin of giant Miocene and Pliocene Cu-Mo deposits in Central Chile: Role of ridge subduction, decreased subduction angle, subduction erosion, crustal thickening and long-lived, batholiths-size, open system magma chambers. in: Porter, T.M., ed., Super Porphyry Copper and Gold Deposits - A Global Perspective: Adelaide, Australia, Porter Geoscience Consultancy Publishing, v. 1, p. 65-82.

Stern, C. R., Skewes, M. A., and Arévalo, A., 2010, Magmatic evolution of the giant El Teniente Cu-Mo deposit, central Chile: Journal of petrology, v. 52, p. 1591-1617.

Tera, F., and Wasserburg, G.J., 1972, U-Th-Pb systematics in three Apollo 14 basalts and the problem of initial Pb in lunar rocks: Earth and Planetary Science Letters, v. 14, p. 281-304.

Ulrich, T., and Heinrich, C.A., 2001, Geology and alteration geochemistry of the porphyry Cu-Au deposit at Bajo de la Alumbrera, Argentina: Economic Geology, v. 96, p. 1719-1742.

Ulrich, T., Günther, D., and Heinrich, C.A., 2002, The evolution of a porphyry Cu-Au deposit, based on LA-ICP-MS analysis of fluid inclusions: Bajo de la Alumbrera, Argentina: Economic Geology, v. 97, p. 1888-1920.

Ulrich, T., and Mavrogenes, J., 2008, An experimental study of the solubility of molybdenum in $\mathrm{H}_{2} \mathrm{O}$ and $\mathrm{KCl}-\mathrm{H}_{2} \mathrm{O}$ solutions from 500 degrees $C$ to 800 degrees C, and 150 to $300 \mathrm{MPa}$ : Geochimica et Cosmochimica Acta, v. 72, p. 2316-2330.

Singer, D. A., Berger, V., I., and Moring, B., C., 2008. Porphyry copper deposits of the world: database and grade and tonnage models. U.S.G.S Open-File Report 2008-1155 (http://pubs.usgs.gov/of/2008/1155).

Vry, V.H., 2010, Geological and hydrothermal fluid evolution at El Teniente, Chile: Unpublished Ph.D. thesis, London, United Kingdom, Imperial College. 78 p.

Vry, V.H., Wilkinson, J. J., Seguel, J., and Millán, J., 2010, Multistage intrusion brecciation and veining at El Teniente, Chile: evolution of a nested porphyry system: Economic Geology, v. 105, p. 119-153.

von Quadt, A., Erni, M., Martinek, K., Moll, M., Peytcheva, I., and Heinrich, C.A., 2011, Zircon crystallization and the life times of ore-forming magmatic-hydrothermal systems: Geology, v. 39, p. 731-734.

Yamamoto, H., and Kennedy, G.C., 1969, Stability relations in the system $\mathrm{CaSO}_{4}-\mathrm{H}_{2} \mathrm{O}$ at high temperatures and pressures: American Journal of Science, v. 267, p. 550-557.

Zajacz, Z., and Halter, W., 2009, Copper transport by high temperature, sulfur-rich magmatic vapor: Evidence from silicate melt and vapor inclusions in a basaltic andesite from the Villarrica volcano (Chile): Earth and Planetary Science Letters, v. 282 , p. $115-121$.

Zhang, L., Audétat, A., and Dolejš, D., 2012, Solubility of molybdenite $\left(\mathrm{MoS}_{2}\right)$ in aqueous fluids at $600-800^{\circ} \mathrm{C}, 200 \mathrm{MPa}$ : A synthetic fluid inclusion study: Geochimica et Cosmochimica Acta, v. 77, p. 175-185. 